Florida International University FIU Digital Commons

3-21-2013

\title{
Influence of Habitat on the Reproductive Ecology of the Amazonian Palm, Mauritia flexuosa, in Roraima, Brazil
}

Roxaneh S. Khorsand Rosa

Florida International University, rkhor001@fiu.edu

DOI: $10.25148 /$ etd.FI13040403

Follow this and additional works at: https://digitalcommons.fiu.edu/etd

\section{Recommended Citation}

Khorsand Rosa, Roxaneh S., "Influence of Habitat on the Reproductive Ecology of the Amazonian Palm, Mauritia flexuosa, in Roraima, Brazil" (2013). FIU Electronic Theses and Dissertations. 842.

https://digitalcommons.fiu.edu/etd/842 


\section{FLORIDA INTERNATIONAL UNIVERSITY}

Miami, Florida

INFLUENCE OF HABITAT ON THE REPRODUCTIVE ECOLOGY OF THE

AMAZONIAN PALM, MAURITIA FLEXUOSA, IN RORAIMA, BRAZIL

A dissertation submitted in partial fulfillment of the

requirements for the degree of

DOCTOR OF PHILOSOPHY

in

BIOLOGY

by

Roxaneh Khorsand Rosa

2013 
To: Dean Kenneth G. Furton

College of Arts and Sciences

This dissertation, written by Roxaneh Khorsand Rosa and entitled, Influence of Habitat on the Reproductive Ecology of the Amazonian Palm, Mauritia flexuosa, in Roraima, Brazil, having been approved in respect to style and intellectual content, is referred to you for judgment.

We have read this dissertation and recommend that it be approved.

David Bray

Maureen Donnelly

Steve Oberbauer

Scott Zona

Suzanne Koptur, Major Professor

Date of Defense: March 21, 2013

The dissertation of Roxaneh Khorsand Rosa is approved.

Dean Kenneth G. Furton

College of Arts and Sciences

Dean Lakshmi N. Reddi

University Graduate School

Florida International University, 2013 


\section{ACKNOWLEDGMENTS}

Throughout this dissertation, many people have graciously shared their shared their time, expertise, creativity, and support with me; to them, I am grateful. Suzanne Koptur, my major professor, consistently supported my outlandish idea of studying a species that most people in the US have never heard of, and in a region where few US or European scientists venture. Despite the many difficulties I encountered along the way, Suzanne continued to encourage me while giving me the intellectual and emotional freedom to make my own decisions. Suzanne is an inspiration to all women who dream of simultaneously being scientists, mentors, educators, mothers, partners, friends, and stewards of the environment.

I am also indebted to my doctoral committee for guiding, challenging, and encouraging me over the past seven years. Each of these individuals has helped me become a better writer. Scott Zona will always be my palm "guru," as he is humble despite his seemingly infininte knowledge of these unique plants. I also thank Scott for teaching me grammar I had long forgotten, and for showing me how to give focused, dynamic oral presentations. Steve Oberbauer challenged me to look at plants from a physiological perspective and supported my adventurous side as a plant ecologist. Steve reminded me to be proud of my work, even when I felt like giving up. Maureen Donnelly joined my committee in 2012, but her influence on me began my first day of graduate school. Mo told me one evening, over shrimp and carambola, that I had one chance to do my $\mathrm{PhD}$. Those simple, yet profound, words carried me through many challenging field days. David Bray represents the "human" dimension of my dissertation, and served as a constant reminder to me that ecological data are futile if we do not use them to advance 
our respectful interactions with the environment. David challenged me to apply my ecological work to the "real world." Jennifer Richards served on my committee from 2006-2012, and pushed me to improve the methodology of my project.

Other individuals at FIU were also critical to the completion of this dissertation. Paulette Johnson and Jay Sah patiently helped me with statistical analyses. Daniel Gann graciously made various versions of maps of field sites. Jessica Schedlbauer spent many hours with me building equipment to measure physiological characteristics of my study species. Larry Noblick (Montgomery Botanical Center) taught me how to climb palms, ensuring me that it is possible to study tall plants and providing the impetus for the many grueling hours I spent collecting data.

My research would not have been possible without the collaboration of several Brazilian colleagues. These individuals serve as an inspiration to scientists in the US, as they do quality work without the resources we take for granted. I admire their tenacity, patience, and sense of humor, and hope I can practice these qualities throughout my career. First and foremost, I am indebted to my collaborator and friend, Reinaldo I. Barbosa (National Institute for Research in Amazonia, INPA, Boa Vista). Reinaldo was critical through every step of data collection; he helped me acquire permits (no easy task in Brazil), allowed me to access INPA and its resources, introduced me to other collaborators, and provided logistical support for fieldwork. Most importantly, I thank Reinaldo for his stimulating conversations about Amazonian ecology, infinite support of a difficult project, and encouragement to make and defend my own research decisions. I am also grateful to Silvio J.R. da Silva, at the Integrated Museum of Roraima (MIRR), for sharing his laboratory with me and identifying floral visitors. Keiko Kusamara 
(MIRR) also shared her laboratory with me. Identification of floral visitors was also performed by Claudio Ruy and Marcio L. Barbosa (INPA, Manaus). I am especially thankful to these entomologists for spending long hours teaching me how to differentiate beetle species. I also thank the following individuals from INPA, Manaus: Gersonval L. Monte and Fernando B.P. Gouveia for identification of visitors, and Ana Maria Pes for teaching me how to photograph visitors.

Fieldwork in Brazil would not have been possible without the determination and courage of my field assistants. Fredson Guedes "Tarzan" is a true warrior, and taught me lessons of bravery, friendship, loyalty, and respect, which reach far beyond fieldwork. I must state for the record, that Tarzan almost died (twice) with me in traumatic Africanized bee attacks, but never quit. We completed the final day of fieldwork together. Itamar S. Firmino and Ricardo P. de Souza ("Ricardinho") were also critical to data collection. I admire their honesty, sense of humor, and stamina; I wish I could climb a palm as fast they do, or walk with painfully heavy backpacks for hours, days in a row, with a blissful negation of pain, as they do. Sebastião Pedro and Elias F. da Silva also helped collect preliminary data. I am also grateful to Kelly B. Ferreira and Maria B. Rosa for their patience sorting, drying, and weighing hundreds of fruits and seeds.

The Brazilian Ministry of the Environment (MMA) granted me permits to work at Maracá Ecological Reserve, under the supervision of the Chico Mendes Institute for Conservation of Biodiversity (ICMBio) (Permits 18307-1, 22967-1). I thank the staff of ICMBio and Maracá Reserve, in particular, the former manager of the Reserve, Gutenberg Moreno. I am also grateful to Wesley G. de Souza at FIT Forestry Management (FIT Manejo Florestal) for granting me access to the Acacia plantations. 
Funding was graciously provided by many sources: National Science Foundation (Doctoral Dissertation Enhancement Project Grant 0906083), Fulbright Commission Brazil (Fulbright Student Grant), National Institute for Research in Amazonia (INPA), International Palm Society, Montgomery Botanical Center, and several scholarships from FIU: Tinker Field Research Grant, Agroecology Scholarship, Pierce Scholarship, Judith Evans Travel Award. My final year of the dissertation was supported by a Dissertation Year Fellowship (FIU). I am also thankful for the many teaching assistantships the Biology Department offered me. Not only did these teaching assistantships allow me to survive financially, but they also helped me find my passion for teaching and provided me with the teaching experience I will carry over into future teaching endeavors.

I thank my family and friends for the unconditional support and love I needed throughout the dissertation. I am privileged to have discovered my passion for ecology as a child, and I owe my family for this privilege. Hossein and Christine Khorsand encouraged me as a child to interact with nature, and supported my childhood dream to be a scientist in the Amazon. My sister, Julia, always encouraged me to dream and stay true to my heart. I am also grateful to my in-laws, the Rosas, for the moral support during my 2.5 years of fieldwork in Roraima. Many friends, both here in the US and dispersed across the globe, have also been critical to the development of my character and the completion of this $\mathrm{PhD}$. I apologize to those I do not mention here. My best friend, Theresa Brighton, has shown me unconditional love for 26 years. Caroline Hammerschlag-Peyer has been a fundamental source of encouragement, wisdom, and love during graduate school. Cary Pirone helped me laugh through some frustrating moments at FIU. The Koptur Lab (Beyte Barrios, Ian Jones, Jaeson Clayborn, and Julia 
Gehring) has become a surrogate family. In Roraima, Flavia S. Pinto, Gabriella Cardoso, and Elsie Licarião helped me establish community in a foreign land. In Manaus, Daniele Kasper "Dani," Rafael "Rafa," and Cícera G. de Lucas opened up their homes to me.

Finally, I thank my husband and friend, Nuno M.B. Rosa. You are part of this dissertation: from my pre-graduate school days as a backpacker through the Amazon, to this final stage in my doctoral career, and all the rich moments in-between. Climbing palms would not have been possible without your creativity and tireless efforts to improve my equipment. This journey would be meaningless without you. 


\begin{abstract}
OF THE DISSERTATION
INFLUENCE OF HABITAT ON THE REPRODUCTIVE ECOLOGY OF THE AMAZONIAN PALM, MAURITIA FLEXUOSA, IN RORAIMA, BRAZIL
\end{abstract} by

Roxaneh Khorsand Rosa

Florida International University, 2013

Miami, Florida

Professor Suzanne Koptur, Major Professor

Although Mauritia flexuosa (Arecaceae) plays a pivotal role in the ecology and economy of the Amazon, and occurs in a variety of habitats, little is known about the influence of habitat on the reproductive biology of this palm. My dissertation focuses on the reproductive biology of $M$. flexuosa in three habitats in Roraima, Brazil: undisturbed forest, undisturbed forest-savanna ecotone, and savanna disturbed by plantations of the exotic tree, Acacia mangium. First, I calculated sex ratios and linked precipitation patterns with phenology. Sex ratios were female-biased. Precipitation was negatively associated with flowering, and positively associated with fruiting. Habitat appears to have no significant influence on phenology of $M$. flexuosa, although short-term climate variation may affect phenology of this species. Second, I examined floral biology, observed floral visitors, and performed exclusion experiments to determine the pollination system of $M$. flexuosa. Fruit set did not differ significantly between the visitor exclusion treatment and the control, but was significantly lowest in the wind + visitor exclusion treatment, suggesting that this dioecious palm is anemophilous, independent of habitat. Third, I identified the abiotic and biotic factors explaining variation in fruit mass, 
seed mass, seed number per fruit, and total fruit yield among habitats. Soil moisture and flooding during the wet season were the best predictors of fruit and seed output. The number of leaves, diameter at breast height, and height were all accurate predictors of reproductive output, but crown volume did not accurately predict fruit yields. Results reevaluate traditional assumptions about wind-pollination in the tropics, and highlight abiotic and biotic factors responsible for variation in reproductive output of $M$. flexuosa, with implications for effective management of this palm. Finally, I interviewed harvesters and vendors to document the traditional knowledge and market dynamics of the fruit of M. flexuosa, buriti. Traditional knowledge corroborated results from scientific studies. Vendors argued that the price of buriti must increase, and must fluctuate with varying supply. With appropriate economic incentives to vendors/harvesters, Roraima may expand its market infrastructure for buriti, effectively stimulating the regional economy and practicing sustainable harvesting. 


\section{TABLE OF CONTENTS}

CHAPTER

PAGE

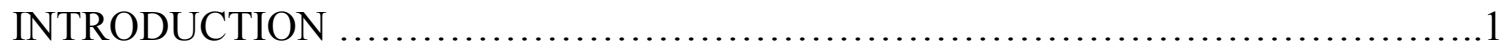

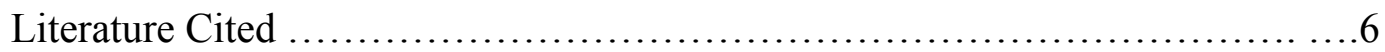

I. HOW DO HABITAT AND CLIMATE VARIATION AFFECT

PHENOLOGY OF THE AMAZONIAN PALM, MAURITIA FLEXUOSA? ......8

Abstract ................................................................. 10

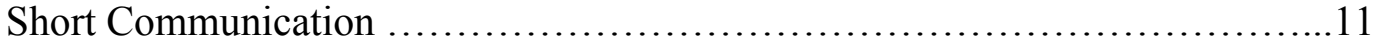

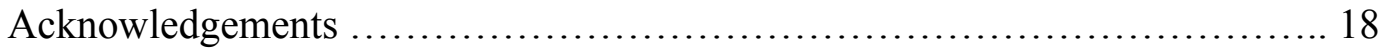

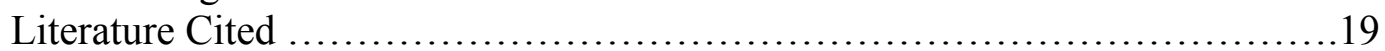

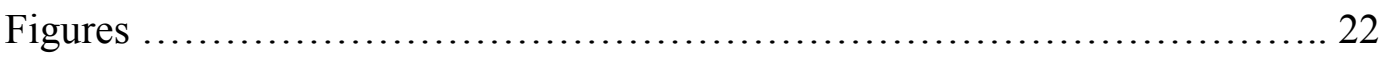

II. NEW FINDINGS ON THE POLLINATION BIOLOGY OF MAURITIA FLEXUOSA (ARECACEAE) IN RORAIMA, BRAZIL:

LINKING DIOECY, WIND, AND HABITAT ...............................23

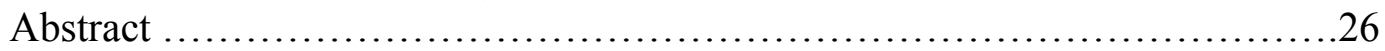

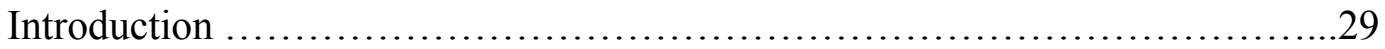

Materials and Methods …...................................................

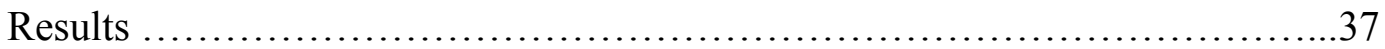

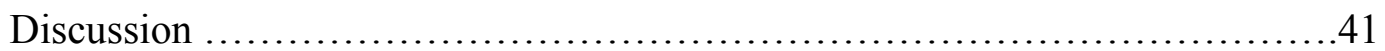

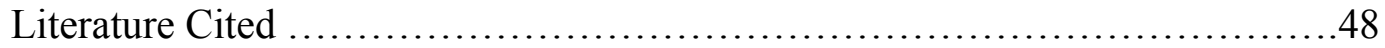

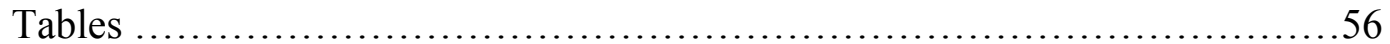

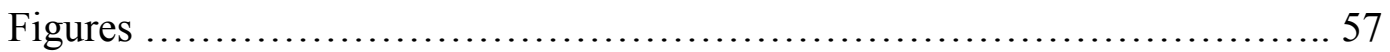

III. ABIOTIC AND BIOTIC FACTORS DRIVING REPRODUCTIVE

OUTPUT OF MAURITIA FLEXUOSA (ARECACEAE):

DOES HABITAT MATTER? ...........................................61

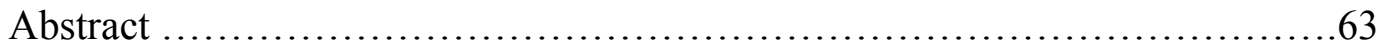

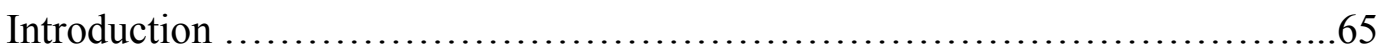

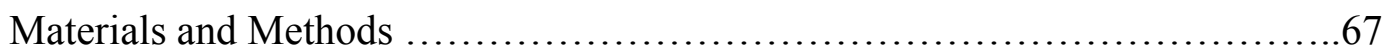

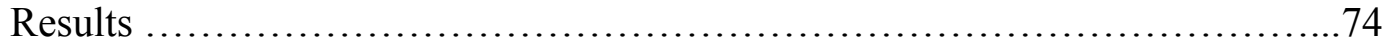

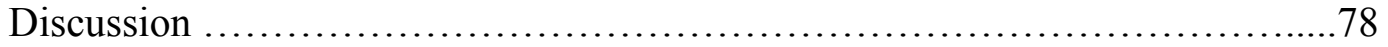

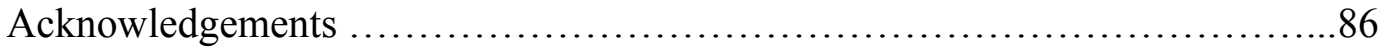

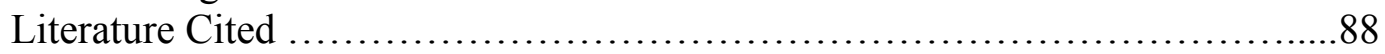

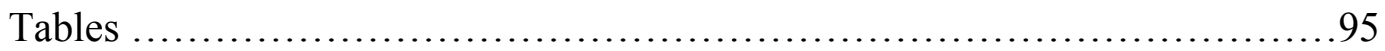

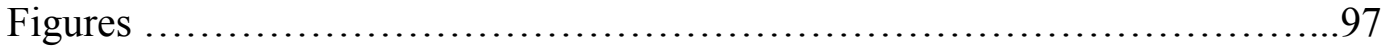

IV. MARKET DYNAMICS OF BURITI (MAURITIA FLEXUOSA)

IN RORAIMA, BRAZIL: THE PATH TO COMMERCIALIZATION .........105

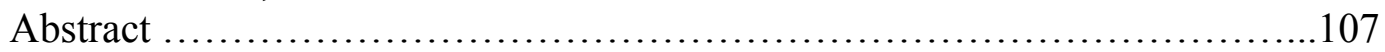

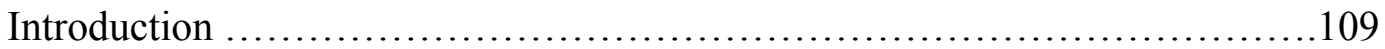

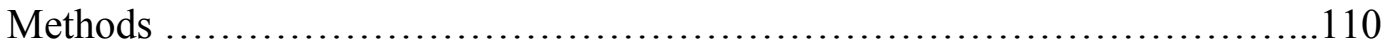

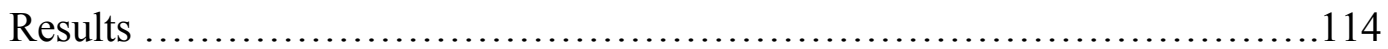




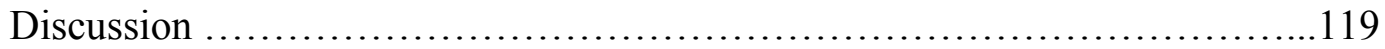

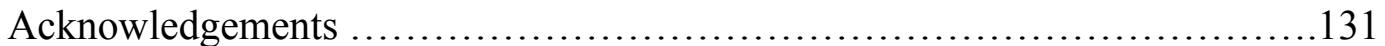

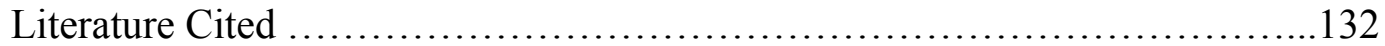

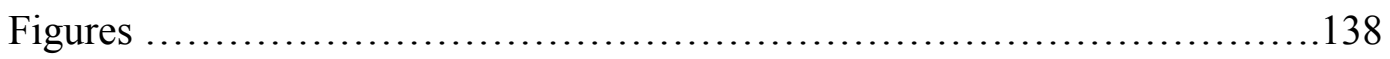

V. CONCLUSIONS AND FUTURE DIRECTIONS .............................. 141

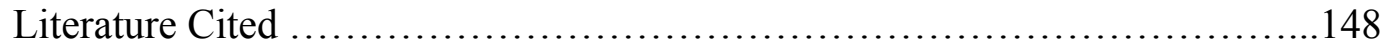

VITA.................................................................... 151 


\section{CHAPTER II}

2.1 The mean number of landings ( \pm SE) by floral visitor family to male and female inflorescences of Mauritia flexuosa in three habitats of Roraima, Brazil; and the proportion of visits in which visitor contacted the sexual floral part (stamen or stigma). Nitidulidae and Cucujidae are lumped together because we were unable to differentiate during field observations. Other/ undet. includes unidentified Dipterans, ants, and one unidentified Coleopteran

\section{CHAPTER III}

3.1 Mean physical and chemical soil parameters for each habitat and year, where UE is undisturbed ecotone, UF is undisturbed forest, and DS is disturbed savanna; and where clay, silt, and sand are \% of total, SB is sum of bases (cmolc/dm3), Al3+ is available aluminum (cmolc/dm3), CEC is total cation exchange capacity (cmolc/dm3), OM is organic matter (\%), $\mathrm{OC}$ is organic carbon $(\%)$, and $\mathrm{V}$ is base saturation $(\%)$; and where ** indicates significance among habitats at $\mathrm{p}<.001$

3.2 Regression equations showing predictors for each response variable: mean number of seeds per fruit, mean seed dry mass $(\mathrm{g})$ per fruit, fruit dry mass (g), and total fruit yield (kg of fruit) per female individual during 2009 and 2010, in Roraima, Brazil; where dbh is diameter at breast height, ht. is total height of the palm (including crown), no. lvs. is number of leaves in the crown, VWC (wet) is volumetric water content during the wet season, and depth is flooding depth during the wet season; and where * of $\mathrm{P}$ indicates significance of regression equation at $\mathrm{P}<0.05$, and $* *$ indicates significance at $\mathrm{P}<0.01$, and NS indicates not significant; and where $*$ in the regression equation indicates significance of predictor at $\mathrm{p}<0.05$. 


\section{LIST OF FIGURES}

PAGE

\section{CHAPTER I}

1.1 Flowering and fruiting of Mauritia flexuosa from March 2009 through February 2011, in Roraima, Brazil. Percentage of all individuals flowering (a); percentage of females with ripe fruit (b). Hatched bars represent savanna and white bars represent forest; dotted line represents mean precipitation (mm); asterisks indicate no data.

\section{CHAPTER II}

2.1 Map of study area in Roraima, Brazil. Sites 1 and 2 comprise savanna ecotone habitat; sites 3 and 4 comprise forest habitat; and sites 5 and 6 comprise disturbed savanna habitat. Sites 1 through 4 are located at Maracá Ecological Reserve (MER). Sites 5 and 6 are located at Núcleo Jacitara, within Acacia mangium plantations. Forest vegetation category includes primary and secondary forest. Given coarse resolution of vegetation cover $(1 \mathrm{~km})$, savanna enclaves on MER appear as forest. Dark clumps represent sampled trees in each site. Source: Global Land Cover 2000 by the Global Vegetation Monitoring Unit of the Joint Research Center.

2.2 Proportion of landings by each insect family on Mauritia flexuosa inflorescences, expressed as the total number of landings by a particular family relative to the total number of landings by all families; and where "other" constitutes unidentified visitors. (A) Male inflorescences, (B) Female inflorescences

2.3 Percent fruit set $( \pm \mathrm{SE}$ ) of Mauritia flexuosa, expressed as the proportion of fruits to flower scars, for each treatment and control; where different letters indicate significant differences at $\alpha=0.05$

2.4 Height ( \pm SE) of Mauritia flexuosa males and females by habitat; where US is undisturbed savanna ecotone, UF is undisturbed forest, and DS is disturbed savanna; and where different letters indicate significant differences within a sex at $\alpha=0.05$ 


\section{CHAPTER III}

3.1 Map of study area in Roraima, Brazil. Sites 1 and 2 comprise savanna ecotone habitat; sites 3 and 4 comprise forest habitat; and sites 5 and 6 comprise disturbed savanna habitat. Sites 1 through 4 are located at Maracá Ecological Reserve (MER). Sites 5 and 6 are located at Núcleo Jacitara, within Acacia mangium plantations. Forest vegetation category includes primary and secondary forest. Given coarse resolution of vegetation cover $(1 \mathrm{~km})$, savanna enclaves on MER appear as forest. Dark clumps represent sampled trees in each site. Source: Global Land Cover 2000 by the Global Vegetation Monitoring Unit of the Joint Research Center.

3.2A Mean number of seeds per fruit produced by Mauritia flexuosa in each habitat in Roraima, Brazil; where UE is undisturbed ecotone, UF is undisturbed forest, and DS is undisturbed savanna; and where different letters indicate significant differences within years (Year 1: $\mathrm{P}<0.001$, Year 2: $\mathrm{P}<0.05$ ). Sample sizes: Year 1: $\mathrm{UE}=276, \mathrm{UF}=281, \mathrm{DS}=275$; Year 2: $\mathrm{UE}=282$, $\mathrm{UF}=326$.

3.2B Mean seed dry mass ( $\mathrm{g}$ ) per fruit produced by Mauritia flexuosa in each habitat in Roraima, Brazil; where UE is undisturbed ecotone, UF is undisturbed forest, and DS is undisturbed savanna; and where different letters indicate significant differences within years $(\mathrm{P}<0.001)$. Sample sizes: Year 1: $\mathrm{UE}=277, \mathrm{UF}=281, \mathrm{DS}=277$; Year 2: $\mathrm{UE}=282, \mathrm{UF}=326 \ldots . .99$

3.2C Mean fruit dry mass (g) produced in each habitat by Mauritia flexuosa in Roraima, Brazil; where UE is undisturbed ecotone, UF is undisturbed forest, and DS is undisturbed savanna; and where different letters indicate significant differences within years $(\mathrm{P}<0.001)$. Sample sizes: Year 1: $\mathrm{UE}=278, \mathrm{UF}=296, \mathrm{DS}=296 ;$ Year $2: \mathrm{UE}=266, \mathrm{UF}=325$

3.2D Mean fruit yield (kg) per Mauritia flexuosa female in each habitat in Roraima, Brazil; where UE is undisturbed ecotone, UF is undisturbed forest, and DS is undisturbed savanna; and where different letters indicate significant differences within years $(\mathrm{P}<0.05)$. Sample sizes: Year 1: $\mathrm{UE}=12, \mathrm{UF}=11$, $\mathrm{DS}=12$; Year 2: $\mathrm{UE}=11, \mathrm{UF}=13$.

3.3A Mean height (m) of Mauritia flexuosa individuals in each habitat in Roraima, Brazil; where UE is undisturbed ecotone, UF is undisturbed forest, and DS is disturbed savanna; and where different letters indicate significance at $\mathrm{P}=0.05$.

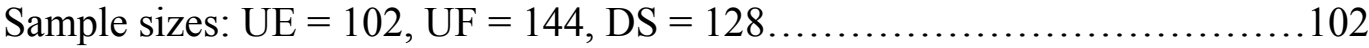

3.3B Mean diameter at breast height $(\mathrm{m})$ of individuals in each habitat in Roraima, Brazil; where UE is undisturbed ecotone, UF is undisturbed forest, and DS is disturbed savanna; and where different letters indicate significance at $\mathrm{P}=0.05$. Sample sizes: $\mathrm{UE}=102, \mathrm{UF}=144, \mathrm{DS}=128$ 
3.3C Mean crown volume $\left(\mathrm{m}^{3}\right)$ of individuals in each habitat in Roraima, Brazil; where UE is undisturbed ecotone, UF is undisturbed forest, and DS is disturbed savanna; and where different letters indicate significance at $\mathrm{P}=0.05$.

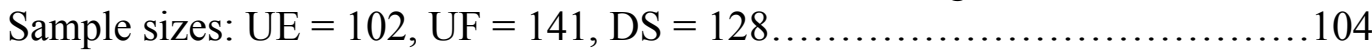

\section{CHAPTER IV}

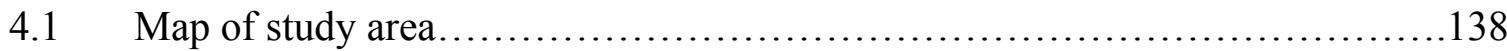

4.2 Mauritia flexuosa population in savanna of Roraima, Brazil. Note male with

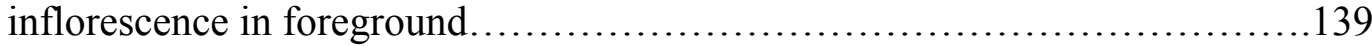

4.3 Sale of buriti fruits in Roraima, Brazil. A. Fruits; B. Vinho for sale C. Buriti fruits ready for processing; D. Filtering vinho before packaging; E. Vendor in Feira do Produtor; note variety of pulps including buriti and açai; F. Vendors in Feira do Garimpeiro selling buriti vinho and açai (in bags)...................140 
INTRODUCTION 
Plant reproduction is critical to terrestrial ecosystem processes (Bawa, 1990; Inouye et al., 2002). The timing of reproduction, as well as the quantity of reproductive output, affects pollination outcome, seed dispersal, plant recruitment, other demographic drivers, and community structure (Ashman et al., 2004; Cleland et al., 2007; Opler et al., 1980; Rathcke and Lacey, 1985). Therefore, synthesizing the relationships between environmental factors, disturbance, and plant reproduction can help us better understand many levels of ecosystem function.

Paradoxically, an inverse relationship exists between plant diversity and our knowledge of such diversity (Prance, 1977). Although plant diversity is highest in the tropics, specifically the Neotropics (Smith et al., 2004), the state of knowledge of Neotropical flora is low (Thomas, 1999). Despite the profound effects climate change and habitat destruction will have on the biodiversity and integrity of Amazonian ecosystems (Malhi et al., 2008), the effects of climate change on plant reproduction is better documented in temperate rather than tropical systems. For example, recent studies examining the relationship between flowering phenology and inter-annual climatic variation attributed to climate change tend to focus on temperate species (Inouye, 2008; Menzel et al., 2006; Willis et al., 2008). Similarly, the effects (both direct and indirect) of climate change and habitat fragmentation on pollination networks have been closely studied in temperate systems (Ashworth et al., 2004; Jennersten, 1988; Memmott et al., 2004), but research is badly needed in tropical systems (Renner, 1998).

Understanding the reproductive biology of tropical plants can not only improve our knowledge of plant diversity and the evolutionary forces driving diversity, but can also improve the way we use and manage plant diversity in the tropics. Carrying out 
effective conservation management of keystone plant species with wide distributions is particularly important because these types of species can have cascading effects on other organisms and processes (McLane and Aitken, 2012).

A central question to plant ecology is: how do external factors affect a plant's ability to reproduce? Different habitats offer different abiotic conditions to plants. Habitat disturbance can alter the types and quantity of resources available for reproductive output (Canham and Marks, 1985). Variation in resource availability influences reproductive success (Solbrig, 1994), with consequences for reproductive and co-evolutionary processes including phenology, pollination, and seed dispersal. Thus, obtaining a complete understanding of the processes that define successful reproduction in a plant species requires data collection from multiple habitats through the entire reproductive trajectory, from flowering to seed production.

The premise of my dissertation focuses on the influence of habitat on the reproductive biology of Mauritia flexuosa (Arecaceae), a keystone species with a broad distribution in South America. By investigating all steps of reproduction in undisturbed and disturbed habitats in Roraima, Brazil, I provide novel information on the phenology, pollination, and reproductive output of M. flexuosa. Further, I elucidate how habitat variation and the presence of an exotic species alter reproductive success in M. flexuosa. Because knowledge of reproductive biology is necessary to sustainably harvest nontimber forest products (NTFPs) such as the fruit of M. flexuosa, or buriti, my research also addresses the market dynamics of buriti in Roraima. An outline of the dissertation follows. 
Chapter I defines the flowering and fruiting periods of M. flexuosa, correlates precipitation with phenology, calculates sex ratios, and determines how the timing and duration of flowering differ among habitats. As I present in this first chapter, phenological response to short-term climate variation, and not habitat, will have implications for distribution patterns and conservation of this keystone species. Chapter I is currently in review by the Journal of Tropical Ecology as a Short Communication.

Chapter II describes floral morphology, measures height dimorphism between sexes, distinguishes between floral visitors and pollinators, and presents results from anemophily and bagging experiments. Results indicate that $M$. flexuosa is windpollinated in all three habitats. The traditional assumptions about wind-pollination are reevaluated and reproductive transitions that have shaped the evolution of reproduction in angiosperms are discussed. Chapter II has been published in the American Journal of Botany.

In Chapter III, I compare fruit and seed production among habitats, identify the abiotic factors that best predict variation in fruit and seed output, and determine which vegetative attributes of $M$. flexuosa can be used to accurately estimate fruit and seed output. Reproductive output varies significantly among habitats, and can best be explained by resource availability, primarily soil moisture. Palm height, diameter at breast height, and number of leaves also accurately predict fruit and seed production. The role of inter-annual climatic variation in reproductive output is also discussed. I plan to submit Chapter III to Annals of Botany and it has been formatted accordingly.

Chapter IV investigates the traditional knowledge of buriti, evaluates the regional market infrastructure and dynamics, and addresses the obstacles that must be overcome to 
commercialize buriti in Roraima, Brazil. Responses from interviews suggest that the local market infrastructure for this NTFP is underdeveloped and demand is stagnant. Lack of transportation and economic incentives, as well as incongruity between price and supply, among other factors, explain the sluggish market of buriti in Roraima. Chapter IV is in review by Economic Botany.

Each of the first three chapters addresses a different aspect of the reproductive biology of $M$. flexuosa in the context of habitat. Chapters I through III present novel data that were acquired by performing field observations and experiments of unmatched sample sizes for this species. Not only do results from this dissertation advance the field of plant reproductive ecology, but also offer practical information to NTFP management and conservation in the tropics. The fourth chapter incorporates some of the results presented in the first three chapters, demonstrating how ecological data can be applied to sustainably use a natural resource. The last chapter also highlights the issues that must be resolved before the commercialization of buriti can effectively stimulate the local economy in an ecologically sustainable manner. Overall, my dissertation fills a small gap in the large dearth of studies in tropical plant ecology, and strengthens collaboration between Florida International University and my collaborating institution in Brazil, National Institute for Research in Amazonia (INPA). 


\section{LITERATURE CITED}

Ashman, T.L., Knight, T.M., Steets, J.A., Amarasekare, P., Burd, M., Campbell, D.R., Dudash, M.R., Johnston, M.O., Mazer, S.J., Mitchell, R.J., Morgan, M.T., and Wilson, W.G. 2004. Pollen limitation of plant reproduction: ecological and evolutionary causes and consequences. Ecology 85(9): 2408-2421.

Ashworth, L., Aguilar, R., Galetto, L., and Aizen, M.A. 2004. Why do pollination generalist and specialist plant species show similar reproductive susceptibility to habitat fragmentation? Journal of Ecology 92(4):717-719.

Bawa, K.S. 1990. Plant-pollinatori nteractionsi n tropical rain forests. Annual Review of Ecology and Systematics 21:399-422.

Canham, C.D. and Marks, P.L. 1985. The ecology of natural disturbance and patch dynamics. New York, Academic Press.

Cleland, E.E., Chuine, I., Menzel, A., Mooney, H.A., and Schwartz, M.D. 2007. Shifting plant phenology in response to global change. Trends in Ecology and Evolution 2(7): 357-365.

Inouye, D.W., Morales, M.A., and Dodge, G.J. 2002. Variation in timing and abundance of flowering by Delphinium barbeyi Huth (Ranunculaceae): the roles of snowpack, frost, and La Niña, in the context of climate change. Oecologia 130:543-550.

Inouye, D.W. 2008. Effects of climate change on phenology, frost damage, and floral abundance of montane wildflowers. Ecology 89:353-362.

Jennersten, O. 1988. Pollination in Dianthus deltoides (caryophyllaceae): effects of habitat fragmentation on visitation and seed set. Conservation Biology 2(4):359366.

Malhi, Y., Timmons Roberts, J., Betts, R.A., Killeen, T.J., Li, W., and Nobre, C.A. 2008. Climate change, deforestation, and the fate of the Amazon. Science 319(5860):169-172.

McLane, S.C. and Aitken, S.N. 2012. Whitebark pine (Pinus albicaulis) assisted migration potential: testing establishment north of the species range. Ecological Applications 22: 142-153.

Memmott, J., Waser, N.M., and Price, M.V. 2004. Tolerance of pollination networks to species extinctions. Proceedings of the Royal Society of London, B, 271:26052611. 
Menzel, A., Sparks, T.H., Estrella, N., Koch, E., Aasa, A., Ahas, R., Alm-Kübler, K., Bissolli, P., Braslavská, O., Briede, A., Chmielewski, F.M., Crepinsek, Z., et al. 2006. European phenological response to climate change matches the warming pattern. Global Change Biology 12(10):1969-1976.

Opler, P.A., Frankie, G.W., and Baker, H.G. 1980. Comparative phenological studies of treelet and shrub species in tropical wet and dry forests in the lowlands of Costa Rica. Journal of Ecology 68:167-188.

Prance, G.T. 1977. Floristic inventory of the Tropics: where do we stand? Annals of the Missouri Botanical Garden 64(4):659-684.

Rathcke, B. and Lacey, E.P. 1985. Phenological patterns of terrestrial plants. Annual Review of Ecology and Systematics 16:179-214.

Renner, S.S. 1998. Effects of habitat fragmentation on plant-pollinator interactions in the tropics. In Newbery, D.M., Prins, H.H.T., and Brown, N., eds. Dynamics of tropical communities, $37^{\text {th }}$ Symposium of the British Ecological Society. Pages 339-360. Oxford, Blackwell.

Solbrig, O.T. 1994. Plant traits and adaptive strategies: their role in ecosystem function. In Shulze, E.D. and Mooney, H.A., eds., Biodiversity and ecosystem function. Pages 97-111.

Smith, N., Mori, S.A., Henderson, A., Stevenson, D.W.M., and Heald, S.V. 2004. Flowering plants of the Neotropics. Princeton, Princeton University Press.

Thomas, W.W. 1999. Conservation and monographic research on the flora of Tropical America. Biodiversity and Conservation 8:1007-1015.

Willis, C.G., Ruhfela, B., Primack, R.B., Miller-Rushing, A.J., and C.D. Davis. 2008. Phylogenetic patterns of species loss in Thoreau's woods are driven by climate change. Proceedings of the National Academy of Sciences 105(44):17029-17033. 


\section{CHAPTER I}

HOW DO HABITAT AND CLIMATE VARIATION AFFECT PHENOLOGY OF THE AMAZONIAN PALM, MAURITIA FLEXUOSA? 


\section{SHORT COMMUNICATION}

Full title: How do habitat and climate variation affect phenology of the Amazonian palm, Mauritia flexuosa?

Running head: Flowering and fruiting of Mauritia flexuosa

Keywords: Amazonian ecology, Arecaceae, Brazil, dioecy, habitat, flower/fruit phenology, palm ecology, sex ratio.

Roxaneh Khorsand Rosa ${ }^{1,3}$, Suzanne Koptur ${ }^{1}$, and Reinaldo Imbrozio Barbosa ${ }^{2}$.

${ }^{1}$ Department of Biological Sciences, Florida International University, University Park, Miami, Florida, 33199, USA;

${ }^{2}$ National Institute for Research in Amazonia-INPA, Department of Environmental Dynamics-CDAM, Nucleus of Roraima, Roraima, Brazil.

${ }^{3}$ Corresponding author; postal address: Florida International University, Department of Biological Sciences, 11200 SW $8^{\text {th }}$ St., Miami, FL., USA, 33139; e-mail: $\underline{\text { rkhor001@,fiu.edu }}$ 


\begin{abstract}
Although the dioecious palm, Mauritia flexuosa plays a pivotal role in Amazonian ecology and economy, little is known about its flowering and fruiting patterns. We investigated the role of habitat and inter-annual precipitation in phenology of M. flexuosa. We calculated sex ratios and recorded phenology for 20 months in four populations $(\mathrm{N}=246)$ of savanna-forest ecotone (two sites) and forest (two sites) habitat in Roraima, Brazilian Amazonia. Sex ratios were significantly female-biased, and $>98 \%$ of females set fruit. No significant relationship was found between habitat and sex. Flowering occurred at the wet/dry season interface, and fruit maturation occurred during the wet season. Males and females flowered synchronously, and neither the onset nor termination of flowering differed significantly between habitats. Precipitation was negatively associated with flowering, and positively associated with fruiting. We conclude that habitat has an insignificant effect, although short-term climatic variation may influence phenology of this species in northern Amazonia. These results highlight the need for long-term studies relating flowering and fruiting events, and inter-annual climatic variation.
\end{abstract}


The timing of flowering and fruiting plays a critical role in plant ecology, influencing community structure and plant-animal interactions (Rathcke \& Lacey 1985).

Phenological analyses are important tools to predict plant community response to climate change and consequences for ecosystem processes (Singh \& Kushwaha 2005). However, studies examining the link between flowering and inter-annual climatic variation tend to focus on temperate species (Agren 1988, Inouye 2008, Kudo \& Hirao 2006). While not a strict dichotomy, water availability triggers flowering in many tropical species (Borchert 1994, Bullock \& Solis-Magallanes 1990), and temperate plants often flower in response to photoperiod and temperature (Hulber et al. 2010).

Habitat can also affect phenological strategies of plants (Croat 1975). Temporal patterns in phenology have been shown to differ between savanna ecotone and forest habitats (Wallace \& Painter 2002). Soil moisture in open and closed habitats can differ, influencing reproductive patterns of plants (Bazzaz 1979). Thus, understanding phenology of broadly distributed species in savanna and forest can help explain distribution patterns of these species, as well as structure of the entire community.

The dioecious palm, Mauritia flexuosa L.f. (Arecaceae) is the most widespread palm in South America (Goulding \& Smith 2007), occurring in savanna, forest, and ecotone habitats. This keystone species provides critical food and habitat for wildlife (Brightsmith 2005, Tobler et al. 2010). Despite its ecological importance, little is known about the relationship between phenology, habitat, and seasonality of M. flexuosa. To understand, and perhaps predict, regeneration patterns of this ubiquitous palm, we must determine the relationships between habitat, precipitation, and phenological events. 
We studied the phenology of M. flexuosa in two native habitats of Roraima, northern Brazilian Amazonia: undisturbed, lowland savanna/forest ecotone (hereafter referred to as savanna) and undisturbed, lowland semi-deciduous forest (hereafter referred to as forest). Three hypotheses were tested: (1) male to female sex ratios are equal in each habitat; (2) the onset and termination of flowering differ between habitats; and (3) flowering and fruiting are seasonal, and correlated with precipitation.

Fieldwork was conducted from March 2009 to March 2011 in Maracá Ecological Reserve $\left(1035 \mathrm{~km}^{2}\right)\left(3^{\circ} 21.21^{\prime} \mathrm{N}, 61^{\circ} 25.47^{\prime} \mathrm{W}\right)$. This tropical wet-dry region, Aw (Köppen 1936), has an average annual rainfall of $1614 \mathrm{~mm}$, with a rainy season (May-September) and a dry season (December-March). Field observations and experiments were conducted in two sites per habitat.

Mauritia flexuosa (Arecaceae) is a solitary, dioecious palm reaching heights of 40 $\mathrm{m}$. Staminate flowers of this anemophilous palm offer copious amounts of dry pollen, but pistillate flowers offer no reward. Both staminate and pistillate flowers open continuously, with individual flowers lasting a maximum of $5 \mathrm{~d}$, and an inflorescence less than 1 wk. Fruits of M. flexuosa are globose and scaly, measuring $4-6 \mathrm{~cm}$ by $3-5 \mathrm{~cm}$, and usually one-seeded (Khorsand Rosa \& Koptur 2013).

At each of the four sites, all M. flexuosa individuals were tagged for sampling within a $200 \times 20$-m transect. Sample size varied between habitats, representative of the natural variability of plant distribution within sites and habitats (undisturbed forest sites: $\mathrm{N}=45, \mathrm{~N}=57$; undisturbed savanna sites: $\mathrm{N}=64, \mathrm{~N}=80$ ).

Sex was determined, and 20 monthly phenological observations were made on marked individuals in each of the four sites. We recorded the number of 
inflorescences/infructescences on each individual, categorizing the developmental stages of flowers and fruits. Percentages of flowering individuals and fruiting females in each habitat were calculated for each month.

A test of independence was employed to determine if a relationship existed between sex and habitat type. Chi-square goodness-of-fit tests were used to compare the male-to-female ratio in each habitat to the expected 1:1.

To obtain the monthly proportion of flowering or fruiting individuals in each habitat, we divided the number of individuals in that phenophase by the total sample size (non-flowering individuals were excluded). Flowering and fruiting curves were created, representing the monthly proportion of flowering and fruiting individuals (\%) in each habitat. To determine the relationship between yearly flowering (or fruiting) and precipitation, Spearman's Rank correlations were conducted on the monthly proportion of flowering or fruiting individuals and mean monthly precipitation. Precipitation means for 2009-2011 were acquired from the National Institute for Spatial Research (INPE).

Kruskal-Wallis tests were performed to determine if the onset and termination of flowering (defined as the earliest/latest DOY on which we observed any degree of flowering in at least $5 \%$ of the population) in males and females differed significantly between habitats. Kruskal-Wallis tests were also used to determine if the mean number of inflorescences differed significantly between sexes, habitats and years.

Non-parametric tests were performed after unsuccessful attempts to transform the non-normally distributed data, and Holm's Sequential Bonferroni correction was applied to all pair-wise comparisons to control for type I error. All statistical analyses were performed in IBM SPSS Statistics version 19 (SPSS, Chicago, Illinois, USA). 
We found a female bias in both habitats (81 males:119 females), deviating significantly from the expected $1: 1\left(\chi_{1}^{2}=7.22, \mathrm{P}=0.007\right)$. However, when habitats were considered separately, the ratio of males to females was significantly different from equality only in the savanna sites $\left(\chi^{2}{ }_{1}=7.91, \mathrm{P}=0.005\right)$, and we found no relationship between habitat and $\operatorname{sex}\left(\chi^{2}{ }_{1}=1.40, \mathrm{P}>0.05\right)$. Nearly all ( $\left.>98 \%\right)$ of the 119 flowering females set fruit.

In both habitats, flowering occurred at the wet/dry season interface, from August to November (Figure 1a). Inflorescence development took 1.7-3.7 mo (mean $\pm \mathrm{SE}=2.06$ $\pm 0.49)$. Neither the onset nor termination of flowering differed significantly between habitats in either year (Onset Yr.1: $\chi^{2}{ }_{1}=2.40, \mathrm{P}>0.05$; Yr.2: $\chi^{2}{ }_{1}=2.67, \mathrm{P}>0.05$; Termination Yr.1: $\chi^{2}{ }_{1}=2.40, \mathrm{P}>0.05 ;$ Yr. $\left.2: \chi^{2}{ }_{1}=0.17, \mathrm{P}>0.05\right)$. Precipitation and flowering were not correlated the first year $\left(r_{s}=0.37, P>0.05\right)$, but negatively correlated the second year $\left(\mathrm{r}_{\mathrm{s}}=-0.71, \mathrm{P}=0.03\right)$.

Fruits were initiated at the beginning of the dry season, and fruit maturation occurred during the wet season, the whole process lasting 8-12 mo. We counted most ripe fruits during the rainy season. In both habitats, the peak dry season (NovemberFebruary) had high numbers of unripe fruits and low numbers of ripe fruits (Figure 1b). Precipitation and ripe fruits were positively correlated, although significant only during the second year $\left(\mathrm{r}_{\mathrm{s}}=0.83, \mathrm{P}<0.01\right)$.

Flowering was synchronized between sexes, and there was no difference in the date of flowering between sexes (Year one: $\chi^{2}{ }_{1}=0.77, \mathrm{P}>0.05$; Year two: $\chi^{2}{ }_{1}=0.54, \mathrm{P}>$ 0.05). One-fifth of females flowered in both years of the study. Males did not produce significantly more inflorescences than females (Year 1: $\chi_{1}^{2}=0.003, \mathrm{P}>0.05$; Year $2: \chi_{1}^{2}$ 
$=1.53, \mathrm{P}>0.05)$. The mean number of inflorescences was significantly greater in the savanna than in the forest during the second year only $\left(\chi_{1}^{2}=6.85, \mathrm{P}=0.009\right)$. Inflorescence production significantly increased during the second year in the savanna habitat $\left(\chi^{2}{ }_{1}=9.55, \mathrm{P}=0.002\right)$, but not in the forest habitat.

Dioecy is associated with obligate outcrossing and variation in spatial distribution of resources, so we expected sex ratios in dioecious species to be equal, or favouring the longer-dispersing sex, males (Bawa 1980). Earlier studies of Mauritia flexuosa have suggested male-biased (Horn et al. 2012) or equal sex ratios (Urrego Giraldo 1987). Selective felling of females for fruit may cause male-biased ratios. Female-biased sex ratios that we observed in the savanna habitat differ from previous reports and our initial hypothesis. Neither harvesting of fruits nor felling of trees had occurred in the four sites we sampled.

Spatial segregation of the sexes (SSS) has been reported in dioecious, windpollinated species (Doust et al. 1997). Females generally have higher resource requirements, so SSS and female-biased ratios should occur in resource-rich microhabitats (Bertiller et al. 2002). Wind-pollinated Mauritia flexuosa may demonstrate SSS, potentially explained by patchy resource distribution. In the forest habitat, where seedlings face competition for space and light, females may not have a selective advantage over males. In the savanna habitat, light and space are less limiting, permitting female-dominance. We found a significant deviation from equality only in the savanna habitat, where $26 \%$ of the population's sex remained undetermined. This topic warrants further investigation. 
In a dioecious species, such as Mauritia flexuosa, some degree of overlap in flowering between sexes is necessary to ensure that males can secure mates (Bateman 1948); our data support this hypothesis. Synchronous flowering in dioecious, windpollinated species may be a strategy to maximize reproductive assurance (Friedman \& Barrett 2009). Contrary to previous reports (Storti 1993) and anecdotal data, females can flower every year, also maximizing reproductive assurance. In addition, $98 \%$ of females set fruit, suggesting an absence of pollen limitation (Khorsand Rosa \& Koptur 2013).

El Niño Southern Oscillation (ENSO) events play a pivotal role in inter-annual climatic variation in northern Amazonia, causing temperature increase and decreased rainfall (Li et al. 2011); ecotonal habitats are especially responsive to seasonal variation (Mayle et al. 2007). The abnormally wet rainy season following the ENSO year may have provided the seasonally dry, ecotonal savanna populations with resources necessary to increase reproductive growth, whereas forest soil moisture remained relatively constant (Hoffmann \& Franco 2003).

In contrast to many species which flower during the dry or wet season (Bawa et al. 2003), flowering of Mauritia flexuosa peaks at the wet/dry interface, when floodwaters recede. The extremely wet conditions of the rainy season and extremely dry conditions of the dry season may stress this species. The juncture between these two extremes, when floodwaters recede, may be the optimal time for reproductive investment. Irradiance and flowering are positively correlated (Hamann 2004). Roraima lies just north of the equator, with a peak dry season associated with low cloud cover and the highest number of irradiance hours (Barbosa et al. in press). Insufficient resources during the peak dry season may prevent flowering, but the wet/dry season transition, 
when M. flexuosa still has access to resource reserves from the wet season and increasing hours of cloudless days of the dry season, may be the ideal time for flowering.

Fruit availability peaks during the wet season in other Amazonian flooded-forest species, aiding in seed dispersal and germination (Haugassen \& Peres 2005). Fruit development should occur during the dry season, when cloudiness is at its lowest, and fruit maturation should occur during the wet season, when seed germination conditions are optimal. Temperature may also play a role in germination of M. flexuosa seeds; Spera et al. (2001) found seed viability decreased when exposed to temperatures of $30^{\circ} \mathrm{C}$ or higher. Increased humidity and lower temperatures, brought on by the rainy season, may provide the optimal conditions for seed germination in this species.

Our results show that sex ratios in M. flexuosa are female-biased, and flowering is seasonal, occurring during the transition from wet to dry season, with fruit maturation occurring during the wet season. Males and females flower synchronously, and the onset and termination of flowering do not differ between habitats. Precipitation is negatively associated with flowering and positively associated with fruiting. Contrary to expectation, habitat does not significantly affect phenology of this species in northern Amazonia. Our data suggest that short-term climatic variation, however, may influence flowering and fruiting patterns. Phenological response to climate variation will have implications for distribution patterns and conservation of this keystone species. 


\section{ACKNOWLEDGMENTS}

Access was granted by the Brazilian Ministry of the Environment (MMA). Funding was from National Science Foundation (0906083), Fulbright-Hayes Commission, and a Dissertation Year Fellowship from Florida International University. We thank: F.

Guedes, I. S. Firmino, S. Pedro, N. M. Rosa, E. F. da Silva, and R. P. de Souza for field assistance; Chico Mendes Biodiversity Institute (ICMBio) and National Institute for Research in Amazonia (INPA) for logistical support; B. Barrios and P. Johnson for statistical assistance; and S. Zona for manuscript improvement. This is contribution number __ to the Florida International University Program in Tropical Biology. 


\section{LITERATURE CITED}

AGREN, J. 1988. Between-year variation in flowering and fruit set in frost-prone and frost-sheltered populations of dioecious Rubus chamaemorus. Oecologia 76:175183.

BATEMAN, A. J. 1948. Intra-sexual selection in Drosophila. Heredity 2: 349-368.

BARBOSA, R. I., MOURÃO JR., M., CASADIO, G. M. L. \& SILVA, S. J. R. In press. Reproductive phenology of the main tree species in the Roraima savanna, Brazilian Amazon. Ecotropica.

BAWA, K. S. 1980. Evolution of dioecy in flowering plants. Annual Review of Ecology and Systematics 11:15-39.

BAWA, K. S., KANG, H. \& GRAYUM, M. H. 2003. Relationships among time, frequency, and duration of flowering in tropical rain forest trees. American Journal of Botany 90:877-887.

BAZZAZ, F. A. 1979. The physiological ecology of plant succession. Annual Review of Ecology and Systematics 10:351-371.

BERTILlER, M. B., SAIN, C. L., BISIGATO, A. J., CORONATO, F. J., ARES, J. O. $\&$ GRAFF, P. 2002. Spatial sex segregation in the dioecious grass Poa ligularis in northern Patagonia: the role of environmental patchiness. Biodiversity and Conservation 11:69-84.

BORCHERT, R. 1994. Soil and stem water storage determine phenology and distribution of tropical dry forest trees. Ecology 75:1437-1449.

BRIGHTSMITH, D. J. 2005. Parrot nesting in southeastern Peru: seasonal patterns and keystone trees. Wilson Bulletin 117:296-305.

BULLOCK, S. H. \& SOLIS-MAGALLANES, J. A. 1990. Phenology of canopy trees of a tropical deciduous forest in Mexico. Biotropica 22:22-35.

CROAT, T. B. 1975. Phenological behavior of habit and habitat classes on Barro Colorado Island (Panama Canal zone). Biotropica 7:270-277.

DOUST, J. L., EL- KEBLAWY, A., FREEMAN, D. C., MCARTHUR, E. D. \& MIGLIA, K. J. 1997. Sexual specialization and inbreeding avoidance in the evolution of dioecy. Botanical Review 63:65-92.

FRIEDMAN, J. \& BARRETT, S. C. H. 2009. Wind of change: new insights on the ecology and evolution of pollination and mating in wind-pollinated plants. Annals of Botany 103:1515-1527.

GOULDING, M. \& SMITH, N. 2007. Palms: sentinels for Amazon conservation. Missouri Botanical Garden Press, St. Louis. 356 pp. 
HAMANN, A. 2004. Flowering and fruiting phenology of a Philippine submontane rain forest: climatic factors as proximate and ultimate causes. Journal of Ecology 92:24-31.

HAUGAASEN, T. \& PERES, C. A. 2005. Tree phenology in adjacent Amazonian flooded and unflooded forests. Biotropica 37:620-630.

HOFFMANN, W. A. \& FRANCO, A. C. 2003. Comparative growth analysis of tropical forest and savanna woody plants using phylogenetically independent contrasts. Journal of Ecology 91:475-484.

HORN, C. M., GILMORE, M. P. \& ENDRESS, B. A. 2012. Ecological and socioeconomic factors influencing aguaje (Mauritia flexuosa) resource management in two indigenous communities in the Peruvian Amazon. Forest Ecology and Management 267:93-103.

HÜLBER, K., WINKLER, M. \& GRABHERR, G. 2010. Intraseasonal climate and habitat-specific variability controls the flowering phenology of high alpine plant species. Functional Ecology 24: 245-252.

INOUYE, D. W. 2008. Effects of climate change on phenology, frost damage, and floral abundance of montane wildflowers. Ecology 89:353-362.

KHORSAND ROSA, R. \& KOPTUR, S. 2013. New findings on the pollination biology of Mauritia flexuosa (Arecaceae) in Roraima, Brazil: linking dioecy, wind, and habitat. American Journal of Botany 100:613-621.

KÖPPEN, W. 1936. Das geographisca System der Climate. Pp. 1-44 in Köppen, W. \& Geiger, G. (eds.). Handbuch der Klimatologie. Gebrüder Borntraeger, Berlin.

KUDO, G. \& HIRAO, A. S. 2006. Habitat-specific responses in the flowering phenology and seed set of alpine plants to climate variation: implications for global-change impacts. Population Ecology 48:49-58.

LI, W., ZHANG, P., YE, J., LI, L. \& BAKER, P. A. 2011. Impact of two different types of El Niño events on the Amazon climate and ecosystem productivity. Journal of Plant Ecology 4:91-99.

MAYLE, F. E., LANGSTROTH, R. P., FISHER, R. A. \& MEIR, P. 2007. Long-term forest-savannah dynamics in the Bolivian Amazon: implications for conservation. Philosophical Transactions of the Royal Society of London (B) 362:291-307.

RATHCKE, B. \& LACEY, E. P. 1985. Phenological patterns of terrestrial plants. Annual Review of Ecology and Systematics 16:179-214. 
SINGH, K. P. \& KUSHWAHA, C. P. 2005. Emerging paradigms of tree phenology in dry tropics. Current Science 89:964-975.

SPERA, M. R. N, CUNHA, R. \& TEIXEIRA, J. B. 2001. Quebra de dormência, viabilidade e conservação de sementes de buriti (Mauritia flexuosa). Pesquisa Agropecuaria Brasileira 12:1567-1572.

STORTI, E. F. 1993. Biologia floral de Mauritia flexuosa Lin. Fil. na região de Manaus, AM, Brasil. Acta Amazônica 23:371-381.

TOBLER, M. W., JANOVEC, J. P., \& CORNEJO, F. 2010. Frugivory and seed dispersal by the lowland tapir Tapirus terrestris in the Peruvian Amazon. Biotropica 42: 215-222.

URREGO GIRALDO, L. E. 1987. Estudio preliminar de la fenologia da la canangucha (Mauritia flexousa L. f.). Colombia Amazónica 2:57-81.

WALLACE, R. B. \& PAINTER, R. L. E. 2002. Phenological patterns in a southern Amazonian tropical forest: implications for sustainable management. Forest Ecology and Management 160:19-33. 
Figure 1. Flowering and fruiting of Mauritia flexuosa from March 2009 through

February 2011, in Roraima, Brazil. Percentage of all individuals flowering (a);

percentage of females with ripe fruit (b). Hatched bars represent savanna and white bars represent forest; dotted line represents mean precipitation $(\mathrm{mm})$; asterisks indicate no data.

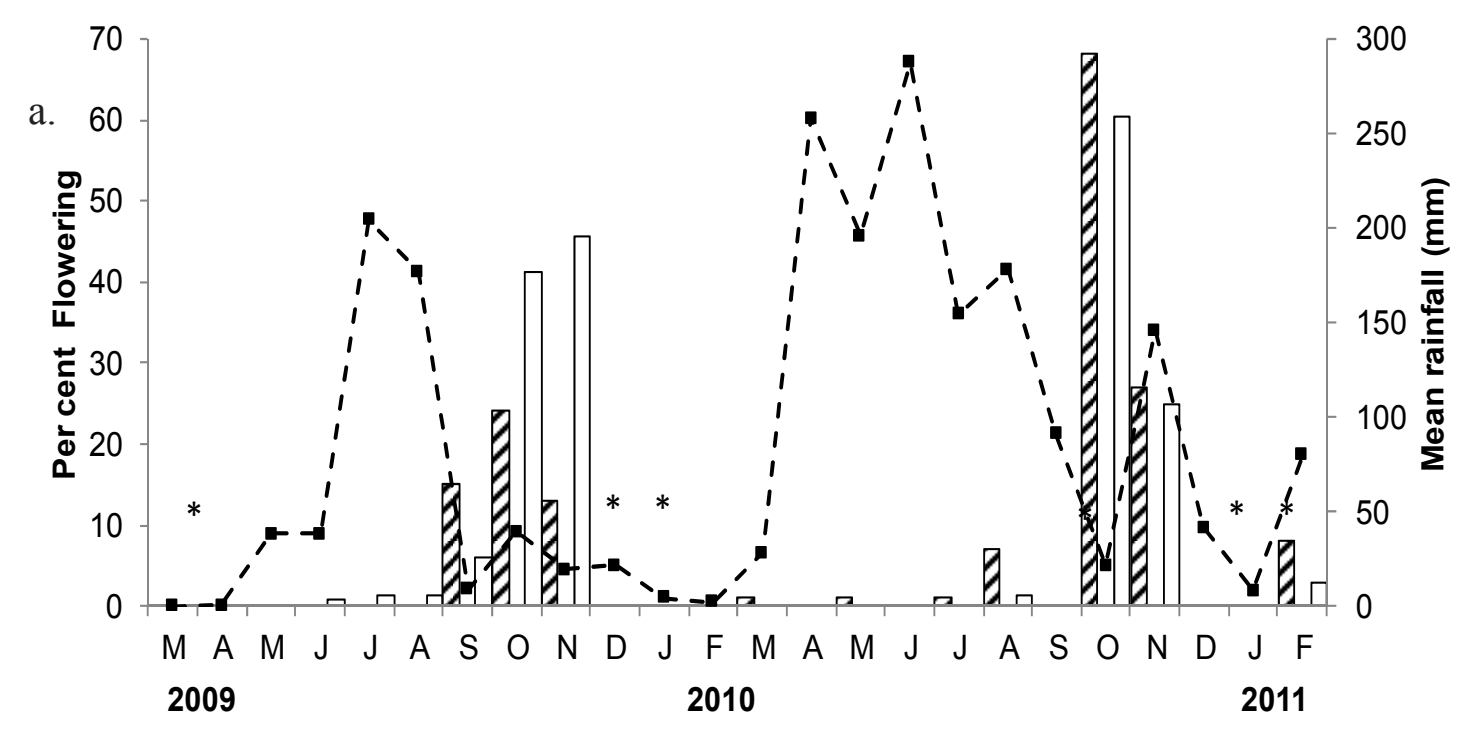

b.

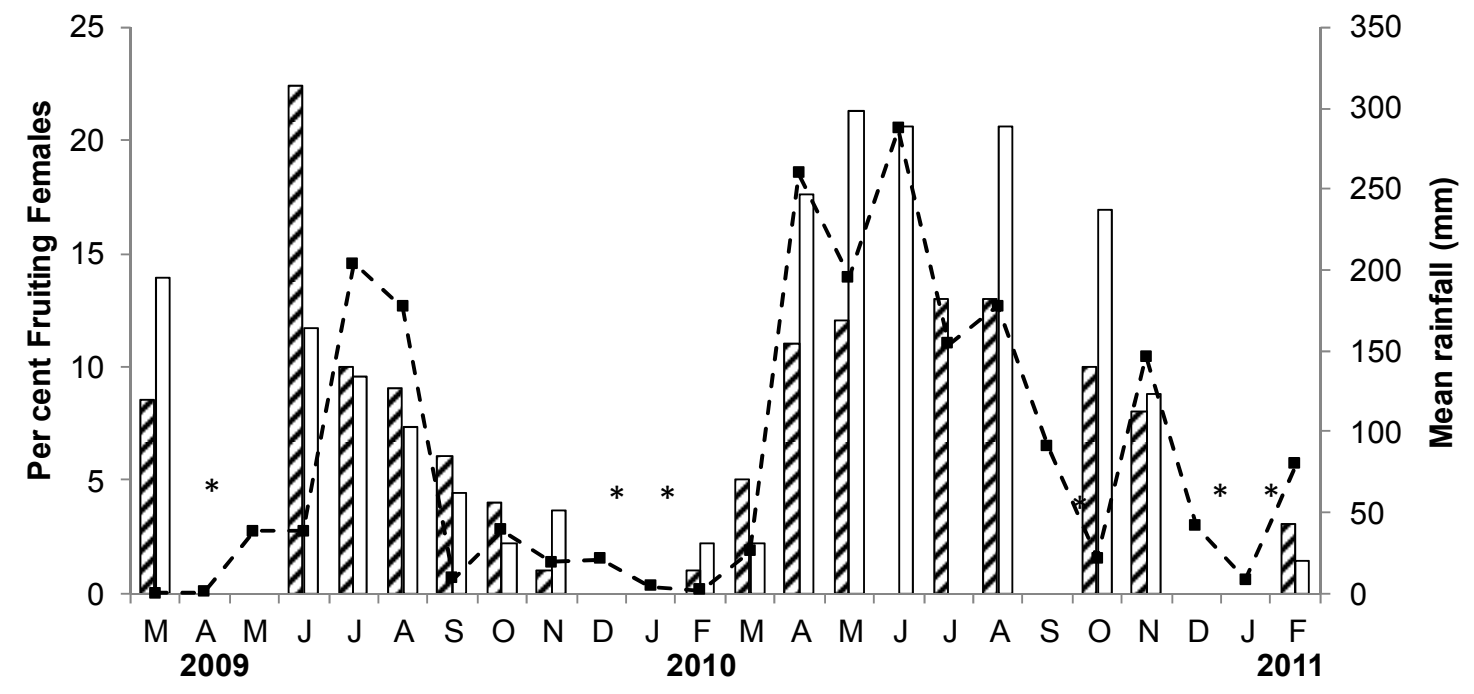


CHAPTER II

NEW FINDINGS ON THE POLLINATION BIOLOGY OF MAURITIA FLEXUOSA (ARECACEAE) IN RORAIMA, BRAZIL: LINKING DIOECY, WIND, AND

HABITAT 
KHORSAND Rosa AND KoPTUR - POLLINATION OF MAURITIA FLEXUOSA

NEW FINDINGS ON THE POLLINATION BIOLOGY OF MAURITIA FLEXUOSA (ARECACEAE) IN RORAIMA, BRAZIL: LINKING DIOECY, WIND, AND HABITAT ${ }^{1}$

ROXANEH KHORSAND ROSA ${ }^{2}$ AND SUZANNE KOPTUR

Department of Biological Sciences, Florida International University, University Park, Miami, Florida, 33199, USA.

${ }^{2}$ Author for correspondence (e-mail: rkhor001@fiu.edu).

${ }^{1}$ Manuscript received _._._._._._._. ; revision accepted 


\section{Acknowledgments}

The authors thank the National Science Foundation (Award No. 0906083), Fulbright-Hayes Commission, Florida International University (FIU), National Institute for Research in Amazonia (INPA), International Palm Society, and Montgomery Botanical Center for funding. A Dissertation Year Fellowship provided critical support during the last year of the dissertation. Access to field sites was granted from the Brazilian Ministry of the Environment (MMA) (Permits 18307-1 and 22967-1). R.I. Barbosa was critical in all stages of field research and data analysis; D. Bray, M. Donnelly, S. Oberbauer, and S. Zona greatly improved the manuscript; P. Johnson and J. Sah provided statistical assistance; and D. Gann created the map of field sites. L. Noblick and N.M.B. Rosa assisted with tree-climbing and equipment; and Brazilian field assistants, F. Guedes, I.S. Firmino, and R.P. de Souza, helped collect data. Maracá Ecological Reserve, Chico Mendes Biodiversity Institute, INPA, and the Integrated Museum of Roraima provided logistical support. S.J.R. da Silva, M.L. Barbosa, and C. Ruy identified visitors; S.J.R. da Silva and K. Kusamura provided laboratory facilities. This is contribution number 246 to the Florida International University Program in Tropical Biology. 
Abstract

- Premise of the study: Despite the ecological, economic, and cultural importance of the palm Mauritia flexuosa in Amazonia, knowledge of its reproductive biology is scarce. Previous observations of this species suggested beetles as the probable pollinator, but experimental work to confirm this hypothesis was lacking.

- Methods: We investigated the floral biology and pollination of $M$. flexuosa in undisturbed forest, undisturbed savanna/forest ecotone, and fragmented savanna within plantations of the exotic tree, Acacia mangium Willd., in northern Brazilian Amazonia. In each habitat, we examined floral biology, combined floral visitor observations with laboratory analyses, and performed anemophily and exclusion experiments.

- Key results: Fruit set was significantly greater in the visitor exclusion treatment than the wind + visitor exclusion treatment, and significantly lower in the wind + visitor exclusion treatment than the open control, but there was no difference in fruit set between the visitor exclusion treatment and the control. We found no significant difference in pollen dispersal among the three habitats. The presence of $A$. mangium appears to have no immediate effect on pollination of $M$. flexuosa, although it may indirectly affect other aspects of this native's reproductive ecology.

- Conclusions: Floral visitors of M. flexuosa are not pollinators. This dioecious palm depends on wind as its primary pollen vector. Wind pollination is not 
necessarily most effective in open habitats. These findings are important because they re-evaluate traditional assumptions of wind pollination, and can improve management strategies of this natural resource in the Amazon.

Key words: Amazon; anemophily; Arecaceae; dioecy; habitat; palm ecology; pollination; reproductive biology.

- Premissa do estudo: Apesar da importância ecológica, econômica e cultural da palmeira Mauritia flexuosa na Amazônia, o conhecimento sobre sua biologia reprodutiva é escasso. Observações anteriores desta espécie sugerem besouros como prováveis polinizadores, mas faltam trabalhos experimentais para confirmar esta hipótese.

- Métodos: Nós investigamos a biologia floral e polinização de M. flexuosa em floresta não-perturbada, ecótono (savana/floresta) não-perturbado, e savana fragmentada por plantações da árvore exótica Acacia mangium Willd., no norte da Amazônia brasileira. Em cada habitat, examinamos a biologia floral, combinamos observações dos visitantes florais com análises de laboratório, e realizamos experimentos de anemofilia e exclusão.

- Resultados chaves: Produção de fruto foi significativamente maior no tratamento de exclusão de visitantes em relação ao tratamento de exclusão de visitante + vento, e significativamente menor no tratamento de exclusão de visitante + vento em relação ao controle, mas não houve diferença significativa entre o tratamento de exclusão de visitante e o controle. Não encontramos diferença significativa na dispersão de pólen entre os três habitats. A presença de A. mangium indica não ter 
efeito imediato na polinização de $M$. flexuosa, embora possa afetar indiretamente outros aspectos da ecologia reprodutiva desta espécie nativa.

- Conclusões: Visitantes florais de M. flexuosa não são polinizadores. Esta palmeira dióica depende do vento como seu vetor primário. Polinização por vento não é necesariamente mais efetiva em habitats abertos. Estes resultados são importantes porque re-avaliam as idéias tradicionais da polinizacão pelo vento, e podem melhorar o manejo deste recurso natural na Amazônia.

Palavras chaves: Amazônia; anemofilia; Arecaceae; dióica; ecologia de palmeiras; habitat; polinização; biologia reprodutiva. 
Introduction

Pollination is a fundamental and critical process of plant reproduction and ecosystem function (Waser and Ollerton, 2006), and has helped shape plant diversity (Torezan-Silingardi, 2012). Understanding the pollination systems of plants is important from both scientific and practical standpoints. However, relatively little is known about the evolution of wind pollination in flowering plants, and the interactions among floral form, mating system, and pollination (Sargent and Otto, 2004; Thomson and Wilson, 2008; Friedman and Barrett, 2009). Describing reproductive transitions, such as those in breeding systems, morphology, and pollination, elucidates the evolutionary forces that have shaped angiosperm reproduction (Specht and Bartlett, 2009; Barrett, 2010a).

From an applied perspective, understanding pollination of plants in agricultural and non-timber forest product (NTFP) systems is necessary to develop practical and sustainable harvesting methods (Klein et al., 2007; Tscharntke et al., 2012). Understanding pollination of wild, harvested plants has profound implications for conservation strategies and land management (de Marco Jr. and Monteiro Coelho, 2004; Hoehn et al., 2010). Results from field observations and experiments of these plants can therefore not only elucidate evolutionary patterns, but may help land managers, harvesters, and policy makers protect and sustainably use these natural resources.

There is a dearth of information on the effects of habitat type and disturbance on pollination (Hadley and Betts, 2012). Although certain pollination systems are commonly associated with specific habitat types, these patterns may vary among species and habitats. Few studies have synthesized how disturbance, particularly the presence of exotic species, affects the pollination and other ecological interactions of native species 
(Pyšek et al., 2012). Quantifying the effects of exotic species on reproductive processes of native plants is crucial to develop effective land management and prevent loss of native biodiversity (Stokes et al., 2006; Lindsay et al., 2011).

Although the dioecious palm, Mauritia flexuosa, plays a central role in Amazonian ecosystems and economies (Goulding and Smith, 2007), little is known about its reproductive ecology. Mauritia flexuosa can be considered a foundation species given the broad consequences it has on associated biota and ecosystem structure (Ellison et al., 2005), such as providing critical food and habitat for wildlife (Henry et al., 2000; Brightsmith, 2005). The fruit is an important part of the diet of Amazonian peoples (Henderson, 1995) and is central to indigenous culture (Mejia, 1988; Horn et al., 2012). Unmatched beta-carotene levels of the fruit highlight the pharmaceutical and industrial applications of this palm (Santos, 2005; Silva et al. 2009; Zanatta et al., 2010). Overharvesting, including the felling of female trees, is a problem in many parts of the Amazon (Holm et al., 2008; Barfod et al., 2011a). Hence, understanding the floral biology and pollination system of this foundation species can improve the way $M$. flexuosa is managed, with important consequences for its ecological processes.

The goal of this research was to investigate the floral biology and pollination system of Mauritia flexuosa in three distinct habitats: undisturbed forest, undisturbed forest-savanna ecotone, and disturbed savanna (within plantations of the exotic tree, Acacia mangium). Cantharophily was previously concluded to be the primary pollination system of M. flexuosa (Ervik 1993, Storti 1993), although pollinators were not distinguished from floral visitors. Ervik (1993) also noted wind-borne pollen for this species, but did not point to wind as the primary vector. We described floral morphology, 
observed and examined floral visitors, and performed anemophily and exclusion experiments to determine if this species depends on animal vectors for its pollination. We also asked how habitat might affect plant-pollinator interactions, and if sexes of this species show height dimorphism, which might play a role in pollen transfer. We tested three specific hypotheses: 1) M. flexuosa is likely to be insect-pollinated, specifically by beetles; 2) Wind plays a secondary role in pollination, although less so in the forest habitat than in the other habitats; and 3) Habitat disturbance negatively affects native floral visitor abundance.

\section{MATERIALS AND METHODS}

Study species-Mauritia flexuosa L. f. (Arecaceae, Calamoideae) is the most widespread palm in South America and is restricted to seasonally wet habitats (Goulding and Smith, 2007). This dioecious palm tolerates continuous flooding, typically forming monodominant stands along streams and rivers, and in swamps. Fruits are globose to ellipsoid, scaly, measuring $4-6 \mathrm{~cm}$ in length and $3-5 \mathrm{~cm}$ in diameter, and usually oneseeded. The thin, scaly exocarp is light orange to dark red, and the fleshy mesocarp is bright yellow-orange. Different morphotypes are identified based on the size, color, and fresh weight of the fruit (Barbosa et al., 2010).

Study area-Fieldwork was conducted in Roraima, Brazil, northern Amazonia (Fig. 1), from March 2009 to March 2011. The climate of this region is considered tropical wet-dry, ‘Aw' (Köppen 1936). Average annual rainfall is $1614 \mathrm{~mm}$, with a mean monthly temperature of $27.8 \pm 0.6^{\circ} \mathrm{C}$ (Barbosa et al. unpublished data). Roraima has two distinct seasons: a rainy season (May through August), and a dry season (December through March). 
Field observations and experiments were carried out in in six sites representing three habitats: (1) undisturbed, lowland savanna-forest ecotone (hereafter referred to as “ecotone"); (2) undisturbed, lowland semi-deciduous forest ("forest"); and (3) former lowland savanna converted to plantations (“disturbed savanna”) of Acacia mangium Willd., a potentially invasive tree (Aguiar Jr., 2010). The four native, undisturbed sites are located at Maracá Ecological Reserve ( $3^{\circ} 21^{\prime} 21^{\prime}$ 'N, $61^{\circ} 25^{\prime} 47^{\prime}$ 'W), a federallyprotected reserve consisting of the world's third-largest riverine island $\left(830 \mathrm{~km}^{2}\right)$, on the Uraricoera River. The two disturbed savanna sites are located at Núcleo Jacitara, $\left(3^{\circ} 12^{\prime} 53^{\prime}{ }^{\prime} \mathrm{N}, 60^{\circ} 49^{\prime} 53^{\prime}, \mathrm{W}\right)$, a $9.16 \mathrm{~km}^{2}$ piece of fragmented, native savanna, of which $3.34 \mathrm{~km}^{2}$ are dense monocultures of Acacia mangium. Mauritia flexuosa occurs naturally within the disturbed sites, and free-roaming cattle and unmanaged Africanized honey bees characterize the area.

Sampling methods - In each M. flexuosa population, we tagged all individuals within a $200 \mathrm{~m}$ by $20 \mathrm{~m}$ transect for sampling. Sample size varied among habitats given natural variability of plant distribution within sites and habitats (Forest sites: $N=45, N=$ 57; Ecotone sites: $N=64, N=80$; Disturbed savanna sites: $N=70, N=58$ ). We climbed study individuals using a custom-made system that is an adaptation of the two-cable prusik system known as a "peia," used by coconut harvesters in northeastern Brazil (Larry Noblick, personal communication).

Floral biology-Monthly monitoring of inflorescences of all sample individuals in all six sites $(N=374)$ was conducted to describe phenology and quantify the duration of anthesis (Khorsand Rosa, submitted). Flower opening time of males and females was investigated by climbing individuals $(N=15)$ and observing floral opening patterns. We 
also noted floral scent, touched stigmas to verify wetness, and tested for the presence of nectar using microcapillary tubes and a hand-held refractometer (Bellingham and Stanley Inc., England ) at various times of the day and night, from $0600 \mathrm{am}$ to $0200 \mathrm{am}$. We randomly selected one inflorescence per individual and counted the number of flowers (male individuals: $N=12$; female: $N=13$ ). Staminate flowers bearing pollen were collected, and pollen was extracted via acetolysis (Kearns and Inouye, 1993) to create pollen-reference slides. Prepared pollen was measured.

Since observing inflorescences for several consecutive days while suspended high up a palm trunk was not feasible, we cut pre-anthesis male and female inflorescences ( $N$ $=6$ ), stored them in sugar-water, and monitored the duration of individual flowers during several days.

Visitor observations - We conducted a total of 81 ten-min observation periods during both flowering seasons (September through November) of 2009 and 2010 in all habitats; 29 observations on 16 male individuals and 53 observations on 18 female individuals. Un-scalable individuals (those that contained Africanized honey bee nests, termite mounds, or irregular trunks) were not used in the study. Most diurnal and all nocturnal observations were made while the observer was in the palm and less than $1 \mathrm{~m}$ from the inflorescence; a few diurnal observations were made from the ground using binoculars. Nocturnal observations were made using a headlamps covered in red cellophane. Since inflorescences are typically at least $1 \mathrm{~m}$ long, we focused our observations on a specific $40-50 \mathrm{~cm}$-long portion of the inflorescence. During each observation, we noted the visitor type present, counted the number of landings of each visitor type, and recorded behavior including: visitation duration, visitation to multiple 
flowers within an inflorescence, and contact with the floral sexual part. We also inspected female flowers for damage made by beetles and signs of oviposition, such as eggs or larvae.

The relative number of landings by each floral visitor family was calculated as the proportion of the family's total landings relative to the total number of landings by all visitors. We also calculated the proportion of landings that resulted in contact with the stigmas or anthers. Proportions were calculated for male and female palms, separately.

Visitors were collected, and in the laboratory, we verified the pollen content on visitors' bodies. Vials in which visitors were stored were centrifuged, and slides of the pellet were scanned for the distinctive, spiny pollen grains of $M$. flexuos $a$ with a light microscope. Floral visitors were identified to family or species by Dr. M.L. Barbosa and Dr. C. Ruy Fonseca (National Insitute for Research in Amazonia (INPA), Manaus, Brazil), and Dr. S.J.R. da Silva (Integrated Museum of Roraima (MIRR), Boa Vista, Brazil). Voucher specimens were deposited in the insect collection of INPA, Manaus, Brazil.

Anemophily experiment - To determine if Mauritia flexuosa pollen is transported by wind, we hung petrolatum (Vaseline ${ }^{\circledR}$ )-covered slides from female inflorescences in all habitats. Microscope slides were sterilized prior to use. A total of 19 slides were hung in the three habitats (ecotone: $N=6$; forest: $N=9$; disturbed savanna: $N=4$ ) on rainless days of similar cloud cover during the 2010 flowering season (September through November). Slides were removed from female trees 3-15 d later, and pollen grains were counted under the light microscope. A one-way ANOVA was conducted on double square-root transformed pollen count data to evaluate if the mean number of pollen grains 
differed significantly among habitats, followed by Tukey's Honest Significant Difference pair-wise comparisons.

Bagging experiment-To determine the pollination system of M. flexuosa, we performed a bagging exclusion experiment in each habitat, consisting of two treatments and a control: 1) a portion of the female inflorescence was enclosed in a fine mesh $(0.5$ $\mathrm{mm}$ ) bag to exclude visitors, but not wind-borne pollen; 2) a portion of the female inflorescence was enclosed in a resin-infused paper bag (Pollen-tector $\left.{ }^{\circledR}\right)$ to exclude visitors and wind-borne pollen; and Control) no bag used, the female inflorescence was open to ambient pollination. We placed each bag on a separate branch of the inflorescence. Unequal sample sizes of females and treatments resulted as a result of the difficulty of climbing these tall palms and fastening bags to inflorescences: ten females received the mesh treatment $(N=15 ; 1-2$ bags per individual), eight females received the paper treatment $(N=8 ; 1$ bag per individual), and nine females received the control $(N=$ 14; 1-2 tagged, unbagged branches per individual). Before bagging flowers, we confirmed that all flowers were closed buds, pollen-free, and no visitors were present. Mesh bags were closed with Velcro® (sewn onto bag lining) and reinforced with wiring; paper bags were first closed with string to ensure a tight fit around the inflorescence branch, then reinforced with wiring. Bags were removed 1-2 mo later, and fruit set was compared with that of the controls. Fruit set was the proportion of fruits to flower scars on the bagged area of the inflorescence.

Fruit set data were arcsin square-root transformed and analyzed using a Mixed Model ANOVA, using treatment as a fixed factor and habitat as a random factor. Least Significant Difference post-hoc tests were performed. 
Sex ratios and sexual dimorphism in height-We tested the hypothesis that males may be taller than females (Friedman and Barrett, 2009) by measuring height of all sample individuals using a clinometer (Suunto Instrument, Finland). Sex ratios were also calculated for each habitat. A test of independence was performed to determine if a relationship existed between sex and habitat type, and a Chi-square goodness-of-fit test was used to determine if the male:female ratio in each habitat deviated significantly from the expected 1:1. We conducted an independent samples t-test on log-transformed height data to determine if height differed significantly between sexes. To determine if height differed significantly among habitats, we performed a one-way ANOVA, followed by pair-wise comparisons. Non-flowering individuals (of undetermined sex) were removed from analyses.

Minimum distance between flowering conspecifics-The minimum distance between sexes theoretically demonstrates how far wind-dispersed pollen must travel for effective pollination. For each female in bloom, we measured the distance to the closest male in bloom. For females in pre-anthesis floral development stage, we measured the distance to the closest male in a similar floral development stage, given that males and females flower synchronously. The mean minimum distance between flowering females and males was compared among habitats using a one-way ANOVA on log-transformed data, followed by Tukey's HSD pair-wise comparisons. A Holm's Sequential Bonferroni correction was performed on all pairwise comparisons to control for Type I error. All statistical analyses were performed in IBM SPSS Statistics version 19 (SPSS, Chicago, Illinois, USA). 


\section{RESULTS}

Floral morphology and phenology - The inflorescences of Mauritia flexuosa are axillary, solitary, and inter-foliar. We counted over 100000 flowers on a single staminate inflorescence $($ mean \pm S.E. $=49938.0 \pm 397.3)$, and up to 6000 flowers on a pistillate inflorescence $(2464.1 \pm 23.4)$. Staminate flowers are borne in dyads, arranged tightly in clusters (18 to 40 flowers per cluster). Pistillate flowers are borne in solitary dyads or triads. Male flowers are smaller (approximately $0.5 \mathrm{~cm}$ by $0.8 \mathrm{~cm}$ ) than female flowers $(1.1 \mathrm{~cm}$ by $1.5 \mathrm{~cm})$, containing three coriaceous petals, six stamens, and a minute pistillode. Female flowers have three coriaceous petals, six staminodes, and a tri-ovulate, scaly gynoecium. The stigmas are dry.

Both staminate and pistillate flowers produce a sweet scent, stronger in males than in females. Knudsen et al. (2001) found 44 volatile compounds present in flowers of M. flexuosa, particularly fatty acid derivatives. No difference was detected in the intensity of fragrance between night or day. Staminate flowers produce copious amounts of dry pollen; pollen grains are round and echinulate (mean \pm S.E. $=61.07 \mu \mathrm{m}, \pm 0.57)$. Pistillate flowers offer no apparent reward. Neither sex produces nectar or resin in the flowers, nor undergoes thermogenesis. Resin is present, however, on developing fruit (Khorsand Rosa, 2011).

Flowering of Mauritia flexuosa in Roraima occurs between the wet and dry seasons (September through November), although variation in precipitation may influence this pattern. Males and females flower in synchrony and do not produce significantly different numbers of inflorescences. Individual flowers did not open at a specific time: both staminate and pistillate flowers opened continuously, with an 
individual flower lasting a maximum of five days, and a single inflorescence less than 1 wk.

Visitor watches-We observed a total of 20 taxa visiting flowers, representing seven insect families. Of these 20 visitor types, 13 visited both staminate and pistillate flowers. Four families accounted for $91 \%$ of all landings in male flowers and $84 \%$ of all landings in female flowers: Curculionidae (Coleoptera), Nitidulidae (Coleoptera), Apidae (Hymenopetera), and Vespidae (Hymenoptera). However, we observed a large difference in the importance of family visitation rates to each sex, measured as the proportion of landings by that family relative to the total number of landings by all families (Figs. 2A, 2B). The most abundant visitors to pistillate flowers were nitidulid and cucujid beetles, comprising $53 \%$ of all landings; these two families only accounted for $12 \%$ of all landings in staminate flowers. We also observed chrysomelid beetles in female flowers, but not in male flowers.

Some insect visitors had a relatively high proportion of landings to both staminate and pistillate flowers, but their behavior suggested they are unlikely to be pollinators (Table 1). Diurnal honey bees (Apis mellifera, Apidae), native Trigona bees (Apidae, Meliponinae), and wasps (Vespidae) actively collected pollen from male flowers, but rarely entered female flowers and contacted the stigmas. Rather, they landed on the vegetative axes of female inflorescences, and foraged around the calyx of the flowers for resin or prey. Weevils were constantly observed in male inflorescences during the day; none were found in female inflorescences during the day.

Although nocturnal visitation rates were higher than diurnal rates, the most abundant floral visitors in female flowers were not those we had observed visiting male 
flowers. Nocturnal visitors to female inflorescences included beetles in the families Chrysomelidae, Nitidulidae, and Cucujidae, as well as Heteroptera (Thaumastocoridae, Xylastodorinae). At night, chrysomelids landed frequently on female flowers, but were not found in male flowers. Nitidulids and cucujids spent up to 5 min at a time in female flowers, and were also observed in male flowers, though much less frequently than in female flowers. Heteropterans visited female flowers at night, although they spent less than 1 min per landing, moving very quickly within the same inflorescence. We did not observe heteropterans on male inflorescences. We also saw ants on male and female inflorescences, comprising the major part of "other" in our classification. However, ants rarely entered female flowers.

Laboratory analyses of floral visitors - We collected a total of 133 individuals. Individuals of the following families were found to have Mauritia flexuosa pollen on their bodies: Curculionidae, Apidae, Vespidae, and Diptera (family undet.). Although weevil individuals (Curculionidae) collected from male flowers carried up to ten pollen grains on their bodies, weevils collected from female flowers carried no pollen grains. Honey bees and native bees (Apidae, Meliponinae, Partamona sp. and Plebeia sp.) collected from male flowers carried up to 100 pollen grains in hairs and corbiculae. Pollen was also found on flies (Diptera), although fewer than 20 grains on a single individual. No pollen was found on visitors (nitidulids, cucujids, and chrysomelids) collected from female inflorescences, or in alcohol in which female floral visitors were stored.

Anemophily experiment - Twelve of the total 19 microscope slides (63\%) that had been suspended from female inflorescences contained M. flexuosa pollen. The 
number of pollen grains per slide in each habitat ranged from zero to 117 grains. There was no significant difference in mean number of pollen grains on slides among the three habitats $\left(F_{2,16}=3.73, P=0.05\right)$.

Bagging experiment - The highest fruit set occurred in the control (mean \pm S.E. $=$ $0.31 \pm 0.04)$, followed by the mesh bag treatment $(0.20 \pm 0.06)$; the lowest fruit set occurred in the paper bag treatment $(0.04 \pm 0.03)$ (Fig. 3). Only treatment had a significant effect on fruit set $\left(F_{2,33.66}=7.53, P=0.002\right)$; we found no significant effect of habitat on fruit set. Pairwise comparisons showed a significant difference in fruit set between the mesh bag treatment (visitor exclusion) and the paper bag treatment (wind + visitor exclusion) $(P=0.019)$, and between the paper bag treatment and the control (open pollination) $(P<0.001)$, but not between the mesh bag treatment and the control $(P=$ 0.10). We noticed dry, undeveloped (presumably aborted) fruits in some of the paper bags, but did not include them in 'fruit set'.

Sex ratios and height - Females significantly outnumbered males across all habitats $\left(\chi^{2}=9.47, P=0.002\right)$, although the sex ratio deviated significantly from the expected 1:1 only in the ecotone habitat $\left(\chi^{2}=7.91, P=0.005\right)$. We did not find a significant relationship between habitat and $\operatorname{sex}\left(\chi^{2}=1.40, P>0.05\right)$. Across all habitats, males were slightly taller than females $(18.70 \pm 0.54 \mathrm{~m}$ vs. $18.23 \pm 0.46 \mathrm{~m})$, although these means were not significantly different from each other $(t=0.636, \mathrm{df}=$ 303, $P=0.71)$ For both sexes, height was greatest in the forest, followed by the ecotone, and shortest in the disturbed savanna (Fig. 4). Height significantly differed between males $\left(F_{2,122}=93.83, P<0.001\right)$, and between females $\left(F_{2,177}=117.30, P<0.001\right)$, 
among the three habitats. All pairwise comparisons between habitats were significant in the analysis of each sex.

Neighborhood size - Male-female inter-individual distances ranged from $1 \mathrm{~m}$ to $50 \mathrm{~m}$ : smallest in the forest habitat (mean $\pm \mathrm{SE}=7.32 \mathrm{~m} \pm 0.71$ ), followed by the ecotone habitat $(11.28 \mathrm{~m} \pm 1.32)$, and largest in the disturbed savanna habitat (11.89 $\mathrm{m} \pm$ 0.90). However, these means did not differ significantly among habitats $\left(F_{2,151}=2.781, P\right.$ $=0.07)$.

\section{DISCUSSION}

Previously, palms (Arecaceae) were thought to be wind-pollinated (Delpino, 1870). Henderson (1986) challenged this paradigm, providing evidence of insectpollination in many palm species. Beetles have been shown to be the most important pollinators of palms (Barfod et al., 2011b). Indeed, the only two published studies on the pollination of Mauritia flexuosa hypothesize beetles to be the probable pollinators (Ervik, 1993; Storti 1993). For effective pollination to occur in a dioecious species, a floral visitor should theoretically visit male inflorescences at a relatively similar frequency to female inflorescences. A pollinating visitor should also carry conspecific pollen on its body. Our results do not satisfy these expectations.

Although native stingless bees and feral Africanized honey bees frequently landed on flowers, the behavior of both types of bees strongly suggests that they are not effective pollinators of $M$. flexuosa. Similar observations have been made on other dioecious species such as Carica, Solanum, and Clusia, in which Trigona bees visit flowers but do not pollinate (Baker, 1976; Anderson and Symon, 1987; Renner and Feil, 1993). Trigona discrimates between floral morphs, ultimately acting as a predator of floral resources, and 
not a pollinator (Janzen, 1975). Ants are also an unlikely pollinator of this species, and are known to hinder pollination processes in most plants as a result of their antibiotic secretions (Beattie et al., 1984).

If Mauritia flexuosa is a wind-pollinated species, we would expect no significant difference in fruit set between the control and visitor exclusion treatment, and a significant difference in fruit set between the control and the wind + visitor exclusion. Our results agree with both of these expectations, providing support for wind-pollination of this species in our study sites. Furthermore, the fact that the majority of slides suspended from female inflorescences contained pollen also supports anemophily. Berry and Gorchov (2004) found similar results in an exclusion experiment of the dioecious palm, Chamaedorea radicalis, and concluded wind to be the primary pollen vector.

The presence of fruit in the paper bag treatment, though less than $4 \%$, raises the possibility of apomixis, specifically agamospermy, in which embryos develop independent of fertilization (Raven et al., 1999). It is unlikely that fruits set inside of bags as a result of contamination; we checked closed flowers and bags for the presence of pollen prior to bagging. Henderson (1995) also suggested that M. flexuosa may be facultatively apomictic because he observed isolated pistillate plants producing viable seeds. The possibility of apomixis has been raised in other dioecious palms including the date palm, Phoenix dactylifera (Abdallah et al., 2001), and Chamaedorea radicalis (Berry and Gorchov, 2004). Facultative apomixis offers dioecious plants a flexible alternative when pollination does not occur (Allem, 2003).

Wind pollination is a derived condition that has arisen on multiple occasions in independent lineages of land plants (Barrett, 2010b). The predominant view for roughly 
the past 140 yrs, articulated by Darwin (1876), is that wind pollination is inefficient, given high pollen:ovule ratios and unpredictable wind aerodynamics (Niklas, 1985; Ackerman, 2000; but see Hall and Walter, 2011). Experimental evidence, however, does not support this charge (Friedman and Barrett 2009). Several features typically associated with anemophily are present in Mauritia flexuosa, including: many flowers, small petals, absence of nectaries, few ovules per flower, prodigious pollen production, unisexual flowers, synchronous flowering, and high conspecific density. There is a strong association between dioecy and wind-pollination (Bawa, 1980), confirmed by Chazdon et al. (2003), who found a significant correlation between unisexual flowers and windpollination, and that wind-pollination was more common in canopy species than understory species. In our forest sites, M. flexuosa can be considered a canopy species, and its inflorescences have full access to the wind.

Many exceptions exist for the constructed pollination "syndromes" (Ollerton et al., 2009), such as the wind-pollination syndrome. The spiny, relatively large pollen grains of M. flexuosa do not contradict anemophily. Sannier et al. (2009) found no significant association between pollen ornamentation and pollination mechanism in palms. Contrary to popular misconception, Wodehouse (1935) found no significant difference in mean pollen size among wind-pollinated species and animal-pollinated species. Wind pollination may be more common in tropical flowering plants than previously thought (Renner and Feil, 1993; Renner and Ricklefs, 1995).

An obvious question remains, however: why should an anemophilous plant invest in floral fragrance? The presence of staminodes and pistillodes suggests that ancestors were hermaphroditic (Anderson et al., 2000), and perhaps entomophilous, the original 
pollination mode in palms (Silberbauer-Gottsberger, 1989). Unisexual flowers and sexual dimorphism are believed to be a derived trait in palms (Tomlinson, 1990). It is also possible that entomophilous ancestors used mimicry to attract floral visitors to rewardless female flowers, similar to that observed in the relative of M. flexuosa, Calamus castaneus (McKey, 2012). Thus, floral fragrance may be a carry-over from an entomophilous ancestor, and has not been selected against because the cost of producing floral scent in this species is, perhaps, minimal. Ambophily, employing both wind and insects for pollination (Culley et al., 2002), may be an intermediate state in the transition from entomophily to anemophily, although we found no evidence of this mechanism in our study.

Wind pollination has traditionally been associated with open, dry habitats (Culley et al., 2002), and thought to be rare in tropical lowland forests (Regal, 1982; but see Chazdon et al., 2003). Our results do not support the claim that pollen grains are more easily dispersed in open areas than forest. Our finding suggests that, in this species, pollen dispersal by the wind is equally effective in the forest as in the savanna. These results suggest that although wind speed and duration may differ among habitats, these differences do not significantly affect the outcome of pollen transport.

The height of M. flexuosa in the forest may facilitate wind-pollination. Individuals in the forest were significantly taller than individuals in either of the savanna habitats. Light limitation is the obvious explanation for this finding, although height may also reflect differences in age. However, it is possible that a height-habitat relationship has also evolved in this species to optimize pollination success. Tree-scale canopy heterogeneity has been shown to affect turbulence characteristics, increasing seed 
dispersal above the canopy (Bohrer et al., 2008). Although pollen may behave differently than seeds in wind currents, it seems reasonable to expect that wind within and above the canopy is capable of dispersing pollen. Other examples of other tropical forest, windpollinated trees include Shorea robusta (Dipterocarpaceae) (Atluri et al., 2004) and Agathis australis (Araucariaceae) (Ecroyd, 1982).

Assuming abundant resources, males tend to be larger than females (Charnov, 1982). Logically, males invest fewer resources in reproductive function and development than females and should be competitively superior in growth (Darwin, 1877; Lloyd and Webb, 1977). However, sexual dimorphism in size may also relate to pollination mechanisms. Male-biased sex allocation is common in anemophilous species (Burd and Allen, 1988; McKone et al., 1998; Hesse and Pannell, 2011). Large males should disperse pollen more effectively than short males because of the interaction between wind aerodynamics and height (Levin and Kerster, 1974; Rosenberg et al., 1983; Niklas, 1985). Similarly, short females should capture pollen more effectively than tall females. An increase in size has been shown to be associated with an increase in maleness, while a decrease in size has been shown to be associated with an increase in femaleness (Bickel and Freeman, 1993; Paquin and Aarssen, 2004). The relationship between sexual system, pollination mechanism, and architectural effects warrants further investigation.

Sex ratio also relates to pollination, as equal male to female ratio increases the probability of successful outcrossing (Anderson et al., 2006). A significant deviation from the expected equal sex ratio only occurred in the ecotone habitat, where $26 \%$ of the population's sex remained undetermined. Sex ratios in this species may be equal, theoretically increasing the probability of successful pollination between sexes by the 
wind. The lack of relationship between sex and habitat also supports our conclusion that wind pollination is important in all three habitats.

Neighborhood size has been proposed as a factor influencing reproductive assurance in wind-pollinated species (Knapp et al., 2001). Based on the fact that the majority of females in our study had access to pollen less than $12 \mathrm{~m}$ away, we conclude that spacing in our sites was amply sufficient for wind-pollination to occur. The tendency of this species to establish in inundated areas may promote closer proximity between sexes. Pollen in the anemophilous, tropical tree, Cecropia obtusifolia, has been shown to travel up to $40 \mathrm{~km}$ (Kaufman et al., 1998), and pollen transport by wind in Phoenix dactylifera has been shown to exceed $200 \mathrm{~m}$ (Almehdi et al., 2005). Given that less than $2 \%$ of all flowering females in our study did not produce fruit suggests that pollen limitation in this species is low, consistent with the prediction that pollen limitation will be uncommon in anemophilous species (Friedman and Barrett, 2009).

Little is known about the evolution of anemophily in Arecaceae from presumed zoophilous ancestors. The few palms known to depend on wind for pollination include Attalea phalerata (Anderson et al., 1988), various species of Chamaedorea (Listabarth, 1993; Otero-Arnaiz and Oyama, 2001; Berry and Gorchov, 2004), Howea (Savolainen et al., 2006), Thrinax parviflora (Read, 1975), and Phoenix dacytylifera (Popenoe, 1922). Listabarth (1993) used the term 'insect-induced pollination' in Chamaedorea pinnatifrons, whereby insects dislodge wind-transferred pollen, and function to aid the wind-pollination system. We did not test for insect-induced pollination in M. flexuosa, because the dry pollen dislodges easily in large quantities by wind. Virtually nothing is known about the pollination systems of the taxonomically closest relatives of Mauritia, 
Lepidocaryum and Mauritiella, or the other species of Mauritia, M. carana Wallace ex Archer. In the distantly related Raphia taedigera, Myers (1984) indicated both wind and insect pollination. Additional studies are needed to better understand the pollination transitions in the evolution of Arecaceae.

Results from field observations, laboratory analyses, and field experiments do not support our stated hypotheses, leading us to draw the following conclusions: 1) Mauritia flexuosa is wind pollinated; 2) habitat and disturbance did not affect the number of pollen grains transferred by wind, and 3) although native floral visitor abundance was lower in the disturbed sites relative to the undisturbed sites, this difference seems irrelevant to anemophilous M. flexuosa. Disturbance may not have immediate consequences on fruit set of abiotically pollinated species, contrary to many biotically pollinated species (Ricketts et al., 2008). However, gene flow may be reduced in fragmented populations, and the presence of the exotic tree (A. mangium) may have indirect effects on the reproductive biology of M. flexuosa and other native plants. We hope that our work encourages others to investigate the possibility of wind-pollination in tropical plants. Results from such studies can elucidate evolutionary transitions in pollination systems and improve conservation and natural resource management practices. 


\section{LITERATURE CITED}

ABDallah, A. B., P. LePoIVRe, AND P. DU JARDin. 2001. Apomixis induction possibility explored in date palm (Phoenix dactylifera L.). Abstract from Proceedings of the Second International Conference on Date Palms, Al-Ain, United Arab Emirates, http://www.pubhort.org/datepalm/datepalm2/datepalm2 22.pdf.

ACKERMAN, J. D. 2000. Abiotic pollen and pollination: ecological, functional, and evolutionary perspectives. Plant Systematics and Evolution 222: 167-185.

AgUiAR JR., A. 2010. Dispersão, distribuição especial e potencial invasor da Acacia mangium Willd. na savana (lavrado) de Roraima. MSc Thesis. Universidade Estadual de Roraima, Boa Vista, Roraima, Brazil.

ALLEM, A.C. 2003. Optimization theory in plant evolution: an overview of long-term evolutionary prospects in the angiosperms. Botanical Review 69: 225-251.

Almehdi, A. M., M. MaraqA, AND S. AbDUlKhalik. 2005. Aerobiological studies and low allergenicity of date-palm pollen in the UAE. International Journal of Environmental Health Research 15: 217-224.

Anderson, G. J., AND D. E. SymON. 1987. Solanum pollinators in Australia. American Journal of Botany 74: 723.

Anderson A. B., B. Overal, AND A. Henderson. 1988. Pollination ecology of a forest dominant palm (Orbignya phalerata Mart.) in Northern Brazil. Biotropica 20: $192-205$.

Anderson, G. J., G. Bernardello, P. Lopez, T. F. Stuessy, And D. J. Crawford. 2000. Dioecy and wind pollination in Pernettya rigida (Ericaceae) of the Juan Fernández Islands. Botanical Journal of the Linnean Society 132: 121-141.

Anderson, G. J., G. Bernardello, M. R. Opel, A. SAntos-Guerra, And M. ANDERSON. 2006. Reproductive biology of the dioecious Canary Islands endemic Withania aristata (Solanaceae). American Journal of Botany 93: 1295-1305.

Atluri, J. B., S. P. Venkata Ramana, AND C. SubBa Reddi. 2004. Explosive pollen release, wind-pollination and mixed mating in the tropical tree Shorea robusta Gaertn. f. (Dipterocarpaceae). Current Science 86: 1416-1419.

BAKER, H. G. 1976. "Mistake pollination" as a reproductive system, with special reference to the Caricaceae. In J. Burley and B. T. Styles [eds.], Tropical trees: variation, breeding and conservation, 161-169. Academic Press, London, England. 
Barbosa, R. I. , A. D. Lima, AND M. Mourão JR. 2010. Biometria de frutos do buriti (Mauritia flexuosa L. f.- Arecaceae): Producão de polpa e óleo em uma área de savana em Roraima. Amazônia: Ciência e Desenvolvimento 5: 71-85.

Barfod, A. S., G. Brokamp, M. Mittelbach, C. A. Grandez, N. Valderrama, And M. WEIGEND. 2011a. Trade in palm products in north-western South America. Botanical Review 77: 571-606.

BARFod, A. S., M. HAGEN, AND F. BorChSENIUS. 2011b. Twenty-five years of progress in understanding pollination mechanisms in palms (Arecaceae). Annals of Botany 108: 1503-1516.

BARRETT, S. C. H. 2010a. Darwin's legacy: the forms, function and sexual diversity of flowers. Philosophical Transactions of the Royal Society, B, Biological Sciences 365: 351-368.

BARRETT, S. C. H. 2010b. Understanding plant reproductive diversity. Philosophical Transactions of the Royal Society, B, Biological Sciences 364: 99-109.

BAwA, K. S. 1980. Evolution of dioecy in flowering plants. Annual Review of Ecology and Systematics 11: 15-39.

Beattie, A. J., C. Turnbull, R. B. Knox, And E. G. Williams. 1984. Ant inhibition of pollen function: a possible reason why ant pollination is rare. American Journal of Botany 71: 421-426.

BERRY, E. J., AND D. L. GORCHOV. 2004. Reproductive biology of the dioecious understorey palm Chamaedorea radicalis in a Mexican cloud forest: pollination vector, flowering phenology and female fecundity. Journal of Tropical Ecology 20: $369-376$.

BicKel, A. M., AND D. C. FREEMAN. 1993. Effects of pollen vector and plant geometry on floral sex ratio in monoecious plants. American Midland Naturalist 130: 239-247.

Bohrer, G., G. G. Katul, R. Nathan, R. L. Walko, And R. Avissar. 2008. Effects of canopy heterogeneity, seed abscission and inertia on wind-driven dispersal kernels of tree seeds. Journal of Ecology 96: 569-580.

Bowler, M., AND R. E. Bodmer. 2011. Diet and food choice in Peruvian Red Uakaris (Cacajao calvus ucayalii): Selective or opportunistic seed predation? International Journal of Primatology 32: 1109-1122.

BRightSMith, D. J. 2005. Parrot nesting in southeastern Peru: seasonal patterns and keystone trees. Wilson Bulletin 117: 296-305. 
Burd, M., AND T. F. H. ALLEN. 1988. Sexual allocation strategy in wind-pollinated plants. Evolution 42:403- 407.

Charnov, E. L. 1982. The theory of sex allocation. Princeton University Press, Princeton, New Jersey, USA.

Chazdon, R. L., S. Careaga, C. WebB, And O. Vargas. 2003. Community and phylogenetic structure of reproductive traits of woody species in wet tropical forests. Ecological Monographs 73:33-348.

Culley, T. M., S. G. Weller, AND A. K. SAKai. 2002. The evolution of wind pollination in angiosperms. Trends in Ecology and Evolution 17: 361-369.

DARWIN, C. 1876. The effects of cross and self-fertilization in the vegetable kingdom, $2^{\text {nd }}$ ed. John Murray, London, England.

DARWIN, C. 1877. The different forms of flowers on plants of the same species. John Murray, London, England.

DELPINO, F. 1870. Ulteriori asservazioni e considerazioni sulla dicogamia nel regno vegetale. Atti della Società Italiana di Scienze Naturali Milano13: 167-205.

DE MARCo JR., P., AND F. MonTeiro Coelho. 2004. Services performed by the ecosystem: forest remnants influence agricultural cultures' pollination and production. Biodiversity and Conservation 13: 1245-1255.

ECROYD, C. E. 1982. Biological flora of New Zealand 8. Agathis australis (D. Don) Lindl. (Araucariaceae) Kauri. New Zealand Journal of Botany 20: 17-36

Ellison, A. M., M. S. BAnk, B. D. Clinton, E. A. Colburn, K. Elliott, C. R. Ford, D. R. FOSTER ET AL. 2005. Loss of foundation species: consequences for the structure and dynamics of forested ecosystems. Frontiers in Ecology and the Environment 3: 479-486.

ERVIK, F. 1993. Notes on the phenology and pollination of the dioecious palm Mauritia flexuosa (Calamoideae) and Aphandra natalia (Phytelephantoideae). In W. Barthlott, C. M. Naumann, K. Schmidt-Loske, and K. L. Schuchmann [eds.], Animal plant interactions in tropical environments, 7-12. Zoologisches Forschunginstitut und Museum Alexander Koenig, Bonn, Germany.

FRIEDMAN, J., AND S. C. H. BARRETT. 2008. A phylogenetic analysis of the evolution of wind pollination in the angiosperms. International Journal of Plant Sciences 169: 49-258. 
Friedman, J., AND S. C. H. BARRETT. 2009. Wind of change: new insights on the ecology and evolution of pollination and mating in wind-pollinated plants. Annals of Botany 103:1515-1527.

Goulding, M., AND N. SMith. 2007. Palms, sentinels for amazon conservation. Amazon Conservation Association, Missouri Botanical Garden Press, St. Louis, Missouri.

Hadley, A. S., AND M. G. BETTS. 2012. The effects of landscape fragmentation on pollination dynamics: absence of evidence not evidence of absence. Biological Reviews 87: 526-544.

HALL, J. A., AND G. H. WALTER. 2011. Does pollen aerodynamics correlate with pollination vector? Pollen settling velocity as a test for wind versus insect pollination among cycads (Gymnospermae: Cycadaceae: Zamiaceae). Biological Journal of the Linnean Society 104: 75-92.

Henderson, A. 1986. A review of pollination studies in the Palmae. The Botanical Review 52: 221-259.

Henderson, A. 1995. The palms of the Amazon. Oxford University Press, New York.

Henry, O., F. FEer, AND D. SABATIER. 2000. Diet of the Lowland Tapir (Tapirus terrestris L.) in French Guiana. Biotropica 32: 364-368.

Hesse, E., AND J. R. PANNELl. 2011. Sexual dimorphism in a dioecious population of the wind-pollinated herb Mercurialis annua: the interactive effects of resource availability and competition. Annals of Botany 107: 1039-1045.

Hoehn, P., I. StefFAn-DewENTER, AND T. TSCHARNTKE. 2010. Relative contribution of agroforestry, rainforest and openland to local and regional bee diversity.

Biodiversity and Conservation 19: 2189-2200.

Holm, J. A., Miller, C. J., AND W. P. Cropper. 2008. Population dynamics of the dioecious Amazonian palm Mauritia flexuosa: simulation analysis of sustainable harvesting. Biotropica 40: 550-558.

Horn, C. M., M. P. GiLmore, AND B. A. EndRESS. 2012. Ecological and socio-economic factors influencing aguaje (Mauritia flexuosa) resource management in two indigenous communities in the Peruvian Amazon. Forest Ecology and Management 267: 93-103.

JANZEN, D. H. 1975. Ecology of plants in the tropics. Edward Arnold, London, England.

Kaufman, S. R., P. E. Smouse, And E. R. Alvarez-Buylla. 1998. Pollen-mediated gene flow and differential male reproductive success in a tropical pioneer tree, 
Cecropia obtusifolia Bertol. (Moraceae): a paternity analysis. Heredity 81: 164173.

KeARns, C. A., AND D. W. InOUYE. 1993. Techniques for pollination biologists.

University Press of Colorado, Niwot, Colorado.

KHORSAND Rosa, R. 2011. Bees collect resin from Mauritia flexuosa in Roraima, Brazil. Palms 55: 200-203.

Klein, A. M., B. E. Vaissière, J. H. Cane, I. Steffan-Dewenter, S. A. Cunningham, C. KREMEN, AND T. TSCHARNTKE. 2007. Importance of pollinators in changing landscapes for world crops. Proceedings of the Royal Society, B, 274: 303-313.

KnApp, E. E., M. A. GoedDE, AND K. J. RicE. 2001. Pollen-limited reproduction in blue oak: implications for wind pollination in fragmented populations. Oecologia 128: $48-55$.

KNudsen, J. T., L. TOlLSTEN, AND F. ERVIK. 2001. Flower scent and pollination in selected Neotropical palms. Plant Biology 3: 642-653.

KÖPPEN, W. 1936. Das geographisca system der climate. In W. Köppen and G. Geiger [eds.]. Handbuch der klimatologie, 1-44. Gebrüder Borntraeger, Berlin, Germany.

LEVIN, D. A., AND H. W. KERSTER. 1974. Gene flow in seed plants. Evolutionary Biology 7: 139-220.

Lindsay, D. L., P. Bailey, R. F. Lance, M. J. Clifford, R. Delph, And N. S. CobB. 2011. Effects of a nonnative, invasive lovegrass on Agave palmeri distribution, abundance, and insect pollinator communities. Biodiversity and Conservation 20: 3251-3266.

LISTABARTH, C. 1993. Insect-induced wind pollination of the palm Chamaedorea pinnatifrons and pollination in the related Wendlandiella sp. Biodiversity and Conservation 1: 39-50.

Lloyd, D. G. AND C. J. WeBB. 1977. Secondary sex characters in plants. The Botanical Review 43: 177-216.

McKey, D. 2012. Flowering phenology and mimicry of the rattan Calamus castaneus (Arecaceae) in southern Thailand. Botany 90: 856-865.

McKone, M. J., C. P. Lund, AND J. M. O'BriEn. 1998. Reproductive biology of two dominant prairie grasses (Andropogon gerardii and Sorghastrum nutans, Poaceae): male-biased sex allocation in wind-pollinated plants? American Journal of Botany 85: 776-783. 
MEJIA, K. 1988. Utilization of palms in eleven Mestizo villages of the Peruvian Amazon (Ucayali River, Department of Loreto). Advances in Economic Botany 6: 130136.

MYERS, R. L. 1984. Growth form, growth characteristics, and phenology of Raphia taedigera in Costa Rican palm swamps. Principes 28: 64-72.

NIKLAS, K. J. 1985. The aerodynamics of wind pollination. The Botanical Review 51: $328-386$.

Ollerton, J., R. Alarcón, N. M. Waser, M. V. Price, S. Watts, L. Cranmer, A. HINGSTON ET AL. 2009. A global test of the pollination syndrome hypothesis. Annals of Botany 103: 1471-1480.

OtERO-ARNAIZ, A., AND K. OYAMA. 2001. Reproductive phenology, seed-set and pollination in Chamaedorea alternans, an understorey dioecious palm in a rain forest in Mexico. Journal of Tropical Ecology 17: 745-754.

PAQUin, V., AND L. W. AARSSEN. 2004. Allometric gender allocation in Ambrosia artemisiifolia (Asteraceae) has adaptive plasticity. American Journal of Botany 91: 430-438.

Popenoe, P. 1922. The pollination of the date palm. Journal of the American Oriental Society 42: 343-354.

Pyšek, P., V. JarošíK, P. E. Hulme, J. Pergl, M. Hejda, U. Schaffner, AND M. VilÀ. 2012. A global assessment of invasive plant impacts on resident species, communities and ecosystems: the interaction of impact measures, invading species' traits and environment. Global Change Biology 18: 1725-1737.

RAVEN, P. H., R. F. EVERT, AND S. E. EICHHORN. 1999. Biology of Plants, $6^{\text {th }}$ ed. W.H. Freeman and Company, New York, New York.

READ, R. W. 1975. The genus Thrinax (Palmae: Coryphoideae). Smithsonian Contributions Botany 19: 1-98.

REGAL, P. J. 1982. Pollination by wind and animals: ecology of geographic patterns. Annual Review of Ecology and Systematics 13: 497-524.

RENNER, S. S., AND J. P. FeIL. 1993. Pollinators of tropical dioecious angiosperms. American Journal of Botany 80: 1100-1107.

RENNER, S. S., AND R. E. RiCKLEFS. 1995. Dioecy and its correlates in the flowering plants. American Journal of Botany 82: 596-606. 
Ricketts, T. H., J. Regetz, I. Steffan-Dewenter, S. A. Cunningham, C. Kremen, A. BoGDANSKI, B. GEMMILL-HERREN ET AL. 2008. Landscape effects on crop pollination services: are there general patterns? Ecology Letters 11: 499-515.

Rosenberg, N. J., B. L. Blad, And S. B. Verma. 1983. Microclimate: the biological environment, $2^{\text {nd }}$ ed. Wiley Press, New York, New York.

SANNIER, J., W. J BAKER, M. C. Anstett, AND S. NADOT. 2009. A comparative analysis of pollinator type and pollen ornamentation in the Araceae and the Arecaceae, two unrelated families of the Monocots. BMC Research Notes 2: 145. doi:10.1186/1756-0500-2-145.

SANTOS, L. M. P. 2005. Nutritional and ecological aspects of buriti or aguaje (Mauritia flexuosa Linnaeus filius): A carotene-rich palm fruit from Latin America. Ecology and Food Nutrition 44: 345-358.

SARGENT, R. D. AND S. P. OTTO. 2004. A phylogenetic analysis of pollination mode and the evolution of dichogamy in angiosperms. Evolutionary Ecology Research 6: 1183-1199.

Savolainen, V., M. C. Anstett, C. Lexer, I. Hutton, J. J. Clarkson, M. V. Norup, M. P. POWELL ET AL. 2006. Sympatric speciation in palms on an oceanic island. Nature Letters 441: 210-213.

Silberbauer-Gottsberger, I. 1989. Pollination and evolution in palms. Phyton 30: 213-233.

Silva, S. M., K. A. Sampaio, T. Taham, S. A. Rocco, R. Ceriani, and A. J. A. MEIRELLES. 2009. Characterization of oil extracted from buriti fruit (Mauritia flexuosa) grown in the Brazilian Amazon region. Journal of American Oil Chemist Society 86: 611-616.

SPECHT, C. D., AND M. E. BARTLETT. 2009. Flower evolution: the origin and subsequent diversification of the angiosperm flower. Annual Review of Ecology, Evolution, and Systematics 40: 217-243.

Stokes, K. E., Y. M. Buckley, AND A. W. ShepPARD. 2006. A modelling approach to estimate the effect of exotic pollinators on exotic weed population dynamics: bumblebees and broom in Australia. Diversity and Distributions 12: 593 - 600.

StorTI, E. F. 1993. Biologia floral de Mauritia flexuosa Lin. Fil. na região de Manaus, AM, Brasil. Acta Amazônica 23: 371-381.

ThOMSON, J. D., AND P. WiLsON. 2008. Explaining evolutionary shifts between bee and hummingbird pollination: convergence, divergence, and directionality. International Journal of Plant Sciences 169: 23-38. 
TomLinson, P. B. 1990. The structural biology of palms. Clarendon Press, Oxford, England.

TOREZAN-SILINGARDI, H. M. 2012. Flores e animais: uma introdução à história natural da polinização. In K. Del-Claro and H. M. Torezan-Silingardi [eds.], Ecologia das interações plantas-animais, uma abordagem ecológico-evolutiva, 113-139. Technical Books Editora, Rio de Janeiro, Brazil.

Tscharntke, T., Y. Clough, T. C. Wanger, L. Jackson, I. Motzke, I. Perfecto, J. VANDERMEER, AND A. WHITBREAD. 2012. Global food security, biodiversity conservation and the future of agricultural intensification. Biological Conservation 151: 53-59.

WASER, N. M., AND J. OlLERTON. 2006. Plant-pollinator interactions, from specialization to generalization. University of Chicago Press, Chicago, Illinois.

WODEHOUSE, R. P. 1935. Pollen grains, their structures, identification and significance in science and medicine. McGraw-Hill, New York, New York.

Zanatta, C. F., M. Mitjans, V. Urgatondo, P. A. Rocha-Filho, And M. P. VINARDELL. 2010. Photoprotective potential of emulsions formulated with Buriti oil (Mauritia flexuosa) against UV irradiation on keratinocytes and fibroblasts cell lines. Food and Chemical Toxicology 48: 70-75. 


\section{TABLES}

TABLE 1 . The mean number of landings ( \pm SE) by floral visitor family to male and female inflorescences of Mauritia flexuosa in three habitats of Roraima, Brazil; and the proportion of visits in which visitor contacted the sexual floral part (stamen or stigma). Nitidulidae and Cucujidae are lumped together because we were unable to differentiate during field observations. Other/ undet. includes unidentified Dipterans, ants, and one unidentified Coleopteran.

\begin{tabular}{|c|c|c|c|c|}
\hline & Male inflo & & Fema & flor. \\
\hline Insect family & $\begin{array}{l}\text { Mean no. landings } \\
( \pm \mathrm{SE})\end{array}$ & $\begin{array}{l}\text { Prop. contact } \\
\text { anthers }\end{array}$ & $\begin{array}{l}\text { Mean no. } \\
\text { landings }( \pm \mathrm{SE})\end{array}$ & $\begin{array}{l}\text { Prop. } \\
\text { contact } \\
\text { stigmas }\end{array}$ \\
\hline Apidae & $8.08,2.23$ & 0.76 & $4.23,1.35$ & 0.14 \\
\hline Chrysomelidae & - & ---------------- & $2.80,0.92$ & 0.80 \\
\hline Curculionidae & $62.75,18.18$ & 0.88 & $1.60,0.60$ & 0.40 \\
\hline Nitidulidae/ & $60.00,40.00$ & 1.00 & $26.89,13.87$ & 0.89 \\
\hline \multicolumn{5}{|l|}{ Cucujidae } \\
\hline Thaumastocoridae & $4.63,1.67$ & 0.14 & $1.75,0.70$ & 0.38 \\
\hline Vespidae & $7.00,2.16$ & 0.50 & $4.00,1.49$ & 0.09 \\
\hline Other/ undet. & $2.53,1.08$ & 0.69 & $1.15,0.46$ & 0.21 \\
\hline
\end{tabular}


Fig. 1. Map of study area in Roraima, Brazil. Sites 1 and 2 comprise savanna ecotone habitat; sites 3 and 4 comprise forest habitat; and sites 5 and 6 comprise disturbed savanna habitat. Sites 1 through 4 are located at Maracá Ecological Reserve (MER). Sites 5 and 6 are located at Núcleo Jacitara, within Acacia mangium plantations. Forest vegetation category includes primary and secondary forest. Given coarse resolution of vegetation cover $(1 \mathrm{~km})$, savanna enclaves on MER appear as forest. Dark clumps represent sampled trees in each site. Source: Global Land Cover 2000 by the Global Vegetation Monitoring Unit of the Joint Research Center.

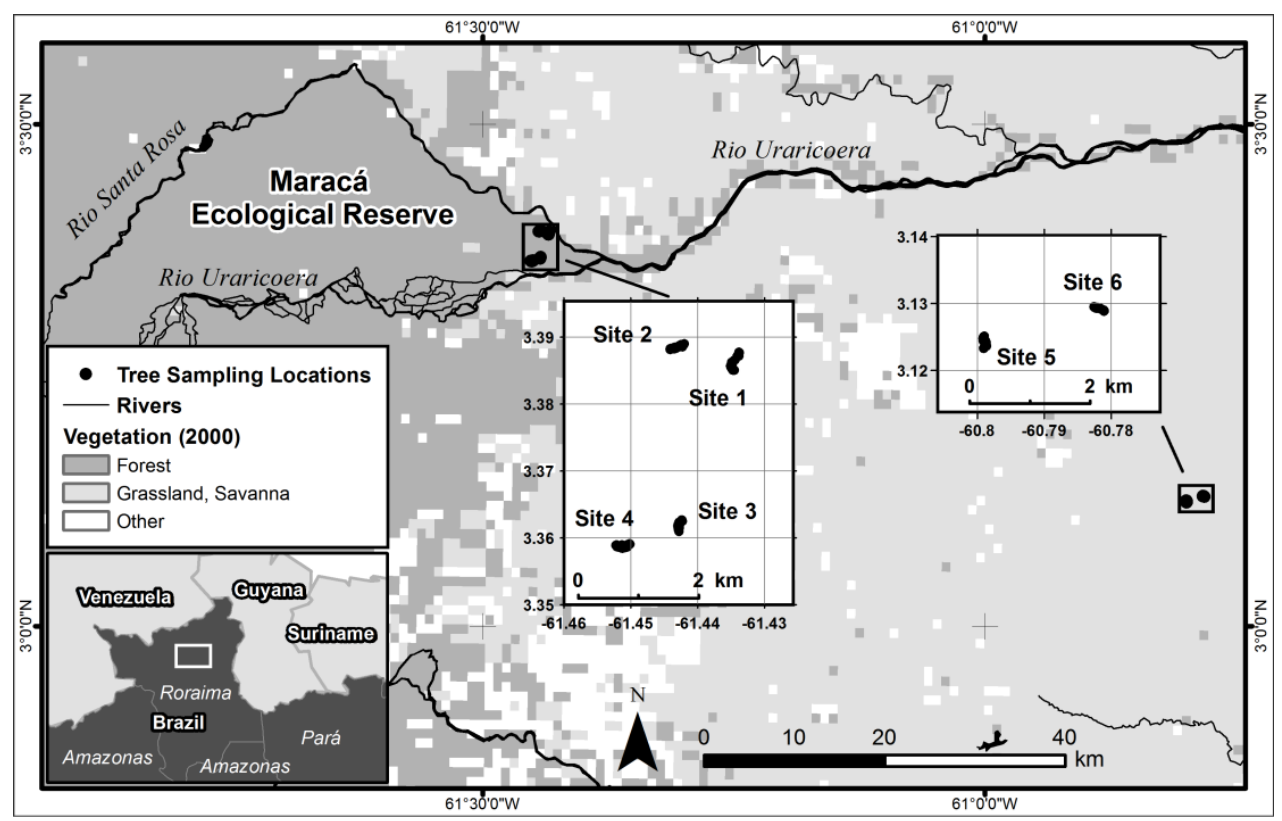


Fig. 2. Proportion of landings by each insect family on Mauritia flexuosa inflorescences, expressed as the total number of landings by a particular family relative to the total number of landings by all families; and where "other" constitutes unidentified visitors.

(A) Male inflorescences, (B) Female inflorescences.

A.

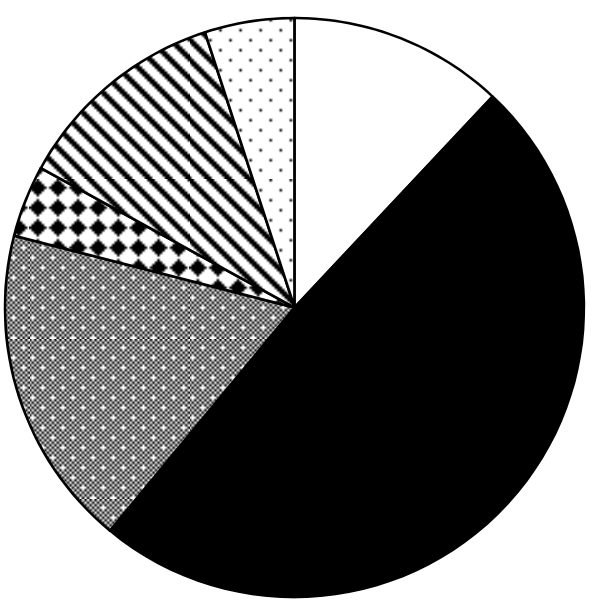

$\square$ Coleoptera,

Nitidulidae/ Cucujidae

- Coleoptera,

Curculionidae

Hymenoptera, Apidae

- Heteroptera,

Thaumastocoridae

$\checkmark$ Hymenoptera,

Vespidae

$\bullet$ Other

B.

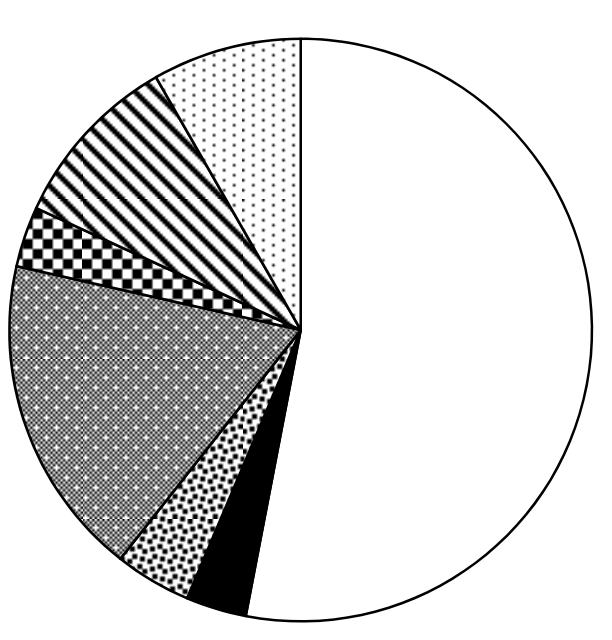

$\square$ Coleoptera,

Nitidulidae/ Cucujidae

- Coleoptera,

Curculionidae

⿴囗十 Coleoptera,

Chrysomelidae

圆Hymenoptera, Apidae

口 Heteroptera,

Thaumastocoridae

sHymenoptera,

Vespidae

๑Other 
Fig. 3. Percent fruit set $( \pm \mathrm{SE}$ ) of Mauritia flexuosa, expressed as the proportion of fruits to flower scars, for each treatment and control; where different letters indicate significant differences at $\alpha=0.05$.

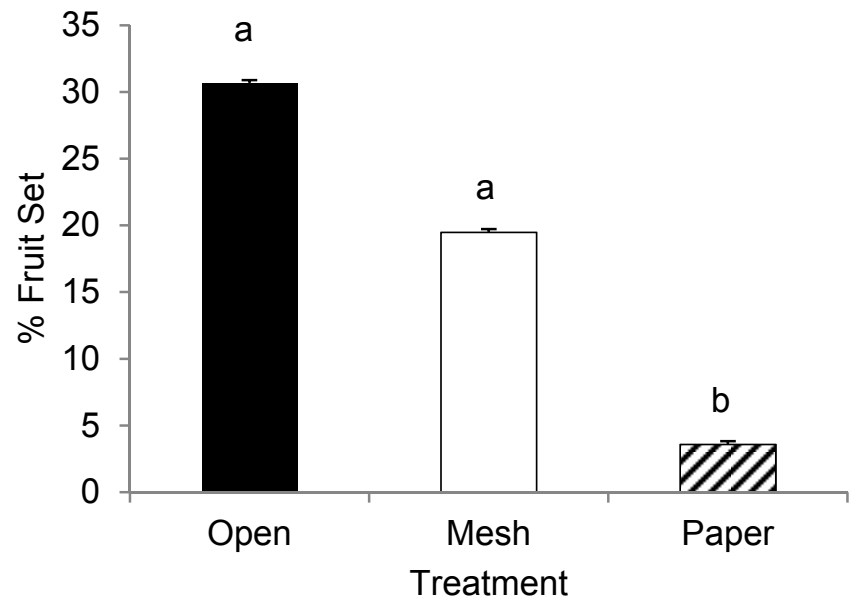


Fig. 4. Height ( \pm SE) of Mauritia flexuosa males and females by habitat; where US is undisturbed savanna ecotone, UF is undisturbed forest, and DS is disturbed savanna; and where different letters indicate significant differences within a sex at $\alpha=0.05$.

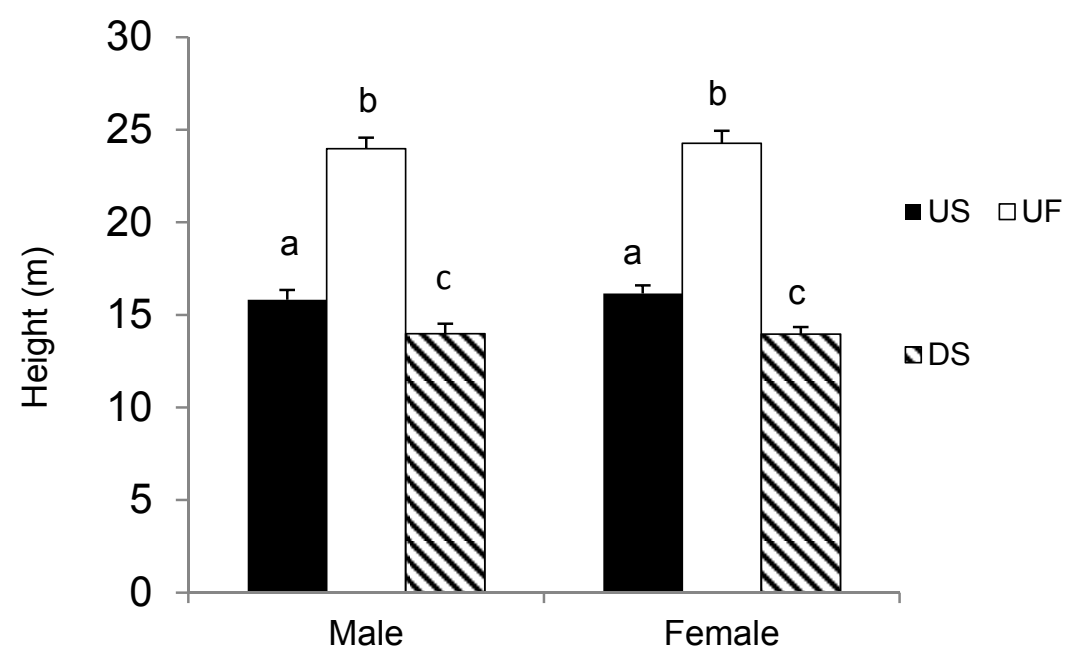




\section{CHAPTER III}

ABIOTIC AND BIOTIC FACTORS DRIVING REPRODUCTIVE OUTPUT OF MAURITIA FLEXUOSA (ARECACEAE): DOES HABITAT MATTER? 
Khorsand Rosa et al. - Habitat and reproductive output of Mauritia

\author{
Abiotic and biotic factors driving reproductive output of Mauritia flexuosa \\ (Arecaceae): Does habitat matter? \\ Roxaneh Khorsand Rosa $^{1 *}$, Reinaldo Imbrozio Barbosa ${ }^{2}$ and Suzanne Koptur ${ }^{1}$ \\ ${ }^{1}$ Department of Biological Sciences, Florida International University, University Park, \\ Miami, Florida, 33199, USA and ${ }^{2}$ National Institute for Research in the Amazon, \\ Department of Environmental Dynamics, R. Coronel Pinto 315 - Centro, 69301-150, Boa \\ Vista, Roraima, Brazil. \\ *For correspondence, E-mail: rkhor001@fiu.edu
}


- Background and aims: The dioecious palm, Mauritia flexuosa, plays a critical role in the ecology and economy of the Amazon. However, little is known about the relationship between habitat heterogeneity and reproductive dynamics of this species. We investigated how fruit and seed production vary among three habitats in northern Brazilian Amazonia, and identified the abiotic and biotic factors explaining this variation.

- Methods: Fruits and seeds from females in six sites (three habitats) were collected. Total fruit yield per individual (kg), dry fruit mass (g), dry seed mass (g), and seed number per fruit were calculated for each female and habitat. Multiple linear regressions were conducted on abiotic (soil physical and chemical parameters, soil moisture, and photosynthetically active radiation) and biotic factors (height, diameter at breast height (dbh), number of leaves, and crown volume) to determine the relationship between these parameters and reproductive output.

- Key results: Fruit mass, seed mass, and seed number were significantly lower in the disturbed savanna than in the undisturbed savanna ecotone and forest, although total fruit yield was highest in the disturbed savanna. Soil moisture and flooding during the wet season were the best predictors of fruit and seed output. Soil organic matter also explained variation in seed mass. The number of leaves, dbh, and height were all accurate predictors of reproductive output, but crown volume should not be used to estimate fruit yields.

- Conclusions: Habitat heterogeneity affects the reproductive dynamics of this species, which can be explained by abiotic factors such as moisture availability and biotic factors such as vegetative attributes. A long-term study relating seasonality, 
environmental factors, and the reproductive dynamics of $M$. flexuosa is warranted, with profound implications for plant reproduction and regeneration patterns.

Key words: Amazonia, disturbance, ecotone, fruit, habitat heterogeneity, Mauritia, seed, reproductive output, vegetative growth. 


\section{INTRODUCTION}

Fruit production and foraging patterns of frugivores play a key role in seed dispersal and plant-disperser coevolution (Howe and Smallwood, 1982), with important consequences for plant recruitment, genetic structure, demography, and vegetative community structure (Hampe, 2008; Nathan et al., 2008). Not only does spatiotemporal variation in fruit supply influence the movement of frugivores across a landscape (Caillaud et al., 2010), but frugivores exert directional selective pressures on plants, thereby influencing species composition (Herrera, 1985). Predicting movement of frugivores, and providing appropriate habitat and corridors, require an understanding of the interaction among habitat, seasonality, and fruit supply (Loiselle and Blake, 1991; Greenberg et al., 2012; Menke et al., 2012). Fruit yield is a key determinant of foraging behavior of primates, with important implications for seed dispersal (Miller and Dietz, 2004). It is particularly important to describe the relationship between seed production and habitat of plant species with broad geographic distributions, as their regeneration patterns strongly affect animal movement and migration as well as other ecosystem processes (McLane and Aitken, 2012; Warren et al., 2012), with clear implications for conservation. Despite the important influence habitat has on consumers, little is known about how habitat heterogeneity and disturbance shape reproductive investment (Cousens et al., 2010; Rodríguez-Pérez et al., 2012). Establishment of the relationship between habitat and plant reproductive dynamics should be a high priority as described above, but to develop a predictive understanding we also need to identify the abiotic and biotic factors that explain this relationship. 
A positive correlation has been established between seed size and recruitment (Jakobsson and Eriksson, 2000). This correlation can be explained by the competitive advantage that large seeds have over small seeds (larger seeds produce larger seedlings) and the superior ability of large seeds to cope with carbon deficits during development (Gross, 1984;

Foster, 1986). In many systems there is interaction among habitat, disturbance, and seed size (Winn, 1985; Hammond and Brown, 1995; Leishman et al., 2000). Clarifying the relationship and possible trade-offs among seed size, seed number, and habitat is important not only to fill the gap in our ecological knowledge, but also for conservation management.

Non-timber forest product (NTFP) species have an increasingly important role in conservation strategies and economic revenue in topical, rural areas (Ticktin, 2004). Maximizing yields of NTFP's in a sustainable manner requires knowledge of their reproductive biology in the context of habitat heterogeneity and environmental change (Hartshorn, 1995). The neotropical palm, Mauritia flexuosa (Arecaceae), plays a central role in the ecology, local economies, and culture of the Amazon (Goulding and Smith, 2007; Horn et al., 2012). The keystone palm provides critical food and habitat for wildlife (Henry et al., 2000; Brightsmith, 2005; Holm et al., 2008). The fruit comprises an important part of the Amazonian diet (Henderson, 1995) and has pharmaceutical and industrial applications given its unmatched levels of beta-carotene (Santos, 2005; Silva et al. 2009; Zanatta et al., 2010). High demand for the fruits in the western Amazon has led to overharvesting, including the felling of female trees (Delgado et al., 2007; Brokamp et al., 2011). Despite this palm's broad importance and the threat of overharvesting, little is known about fruit yields and habitat heterogeneity. Quantifying fruit production in native 
and disturbed habitats can increase the efficiency of harvesting efforts. Identifying the environmental factors driving reproductive output, and determining a possible correlation between vegetative and reproductive biometrics, can also help managers maximize fruit yields sustainably.

We investigated the role of habitat in fruit and seed production of Mauritia flexuosa in three habitats in Roraima, Brazil, and determined which factors influence these reproductive measures. Our study asked three questions: 1) Do fruit and seed production vary significantly among habitats; 2) Which abiotic and biotic factors affect fruit and seed production; and 3) Can vegetative attributes of M. flexuosa accurately predict fruit and seed production?

\section{MATERIALS AND METHODS}

\section{Study area}

Fieldwork was conducted in Roraima, Brazil, northern Amazonia (Fig. 1), from March 2009 to March 2011. Roraima is an expansive mosaic of savanna and forest ecosystems that are part of the "Rio Branco- Rupununi Complex," comprising the largest continuous block of savannas in the Amazon $\left( \pm 40000 \mathrm{~km}^{2}\right)$ (Barbosa and Fearnside, 2005). The climate of this region is considered tropical wet-dry, 'Aw' (Köppen 1936). Average annual rainfall is $1614 \mathrm{~mm}$, with a mean monthly temperature of $27.8 \pm 0.6^{\circ} \mathrm{C}$ (Barbosa et al., 2012). Roraima has two distinct seasons: a rainy season (May through August), and a dry season (December through March).

Six populations representing three habitats were included in our study: (1) undisturbed, lowland savanna-forest ecotone (hereafter referred to as "ecotone"); (2) undisturbed, lowland semi-deciduous forest ("forest"); and (3) former lowland savanna converted to 
plantations (“disturbed savanna") of the exotic tree, Acacia mangium Willd. The four undisturbed sites (two ecotone and two forest sites) are located at Maracá Ecological Reserve $\left(3^{\circ} 21^{\prime} 21^{\prime}{ }^{\prime} \mathrm{N}, 61^{\circ} 25^{\prime} 47^{\prime}\right.$ ' $\left.\mathrm{W}\right)$, a $1035 \mathrm{~km}^{2}$ federally-protected reserve, containing the world's third-largest riverine island, on the Uraricoera River. The two disturbed savanna sites are located at Núcleo Jacitara, $\left(3^{\circ} 12^{\prime} 53^{\prime}{ }^{\prime} \mathrm{N}, 60^{\circ} 49^{\prime} 53^{\prime \prime} \mathrm{W}\right)$, a $9.16 \mathrm{~km}^{2}$ piece of fragmented, native savanna, of which $3.34 \mathrm{~km}^{2}$ are dense monocultures of Acacia mangium. Mauritia flexuosa occurs naturally within the disturbed sites, where cattle and unmanaged Africanized honey bees are also present.

\section{Study species}

Mauritia flexuosa L. f. (Arecaceae, Calamoideae) is the most widespread palm in South America and one of the most massive, reaching heights of up to $40 \mathrm{~m}$ (Goulding and Smith, 2007; Khorsand Rosa, unpubl. data). This dioecious palm tolerates flooding, typically forming monodominant stands along streams, and in swamps. Flowering in Roraima is annual, occurring between the wet and dry seasons (September through November), and fruit maturation takes place during the peak wet season (April through July). Precipitation has been found to be negatively associated with flowering and positively associated with fruiting. Females can set fruit during consecutive fruiting seasons (Khorsand Rosa, unpubl. data). Fruits are globose to ellipsoid, scaly, measuring 4-6 cm in length and 3-5 cm in diameter, and usually one-seeded. The thin, scaly exocarp is light orange to dark red, and the fleshy mesocarp is bright yellow-orange. Five morphotypes have been identified on the basis of size, form, and exocarp color (Barbosa et al., 2010). Cultivation of M. flexuosa is rare, explaining the lack of horticultural information known about this species. Small communities in the Amazon 
have begun cultivation initiatives (Manzi and Coomes, 2009), although many of these projects may not yet be disseminated to science. No studies have examined the time it takes for females from seed to set fruit, although anecdotal data suggest a minimum of ten years (Khorsand Rosa, pers. obs.).

\section{Sampling methods}

We tagged all individuals within a $200 \times 20 \mathrm{~m}$ transect for sampling in each of the six sites. Sample size varied among habitats given natural variability of plant distribution within sites and habitats (Ecotone sites: $N=64, N=80$; Forest sites: $N=45, N=57$; Disturbed savanna sites: $N=70, N=58$ ). To climb study individuals, we developed a custom-made system that is an adaptation of the two-cable prusik system known as a "peia," used by coconut harvesters in northeastern Brazil (Larry Noblick, personal communication).

\section{Fruit and seed collection}

During the fruiting seasons of 2009 and 2010, we randomly selected three to eight females with mature fruit in each site $(2009: N=35 ; 2010: N=24)$. In 2010, fruits were not collected in the disturbed savanna sites because of unsafe field conditions (e.g. Africanized bee attacks). We climbed each female and cut one randomly- selected infructescence. The total number of fruits per infructescence was counted, and all fruits were weighed to determine the total (reproductive) weight $(\mathrm{kg})$ of the infructescence. We also counted the total number of infructescences on the study individual to estimate the total fruit yield $(\mathrm{kg})$ produced by each female. Fifty fruits were randomly selected for laboratory analyses. 
In the lab, 25 fruits were dried in an oven at $70^{\circ} \mathrm{C}$ until constant weight was obtained (7-9 days), and weighed with an electronic balance (0.01g accuracy). The other 25 fruits were soaked in water for 24 hours to allow for seed removal, and dried at $70^{\circ} \mathrm{C}$ until constant weight was obtained. All fruits and seeds were weighed, although a few seeds were very small and may have been sterile. In this study, we refer to fruit or seed mass as weight, assessed by an electronic balance, as fruit or seed mass indicate fruit or seed size.

\section{Soil parameters}

Soil samples were collected at $20 \mathrm{~cm}$ depth from each site during September $2009(N=$ 102) and March $2010(N=180)$, representing the end of the wet and dry seasons, respectively. Soil was collected from 17 randomly selected individuals per site during the first year, and 30 randomly selected individuals per site during the second year. We increased the sample size during the second year to account for high variability observed within sites during the first year. Soil was collected from four cardinal points equidistant $(1 \mathrm{~m})$ from the tree at $20 \mathrm{~cm}$ depth and mixed together, yielding one sub-sample. All soil samples were air dried prior to being delivered to the soil laboratory of the Brazilian Enterprise for Agricultural Research (EMBRAPA), Boa Vista, Roraima, Brazil. Physical properties (soil texture: \% sand, silt, and clay) and chemical properties (pH, exchangeable $\mathrm{Ca}^{2+}, \mathrm{Mg}^{2+}, \mathrm{K}^{+}, \mathrm{Na}$, available $\mathrm{P}, \mathrm{Al}^{3+}$, total cation exchange capacity (CEC), organic matter, and organic C) were analyzed.

A granulometric analysis was performed to differentiate soil texture determined by pipette method (Gee and Bauder, 1986). Sand, silt, and clay were dispersed using water and sodium hexametaphosphate (Calgon $\left.{ }^{\circledR}\right)$. 
Soil $\mathrm{pH}$ was determined using a suspension of water and $0.01 \mathrm{M} \mathrm{CaCl}_{2}$. The double acid extraction method (Mehlich No.1) was used to determine exchangeable $\mathrm{Ca}, \mathrm{Mg}, \mathrm{K}, \mathrm{NaCl}$ and available $\mathrm{P}\left(\mathrm{H}_{2} \mathrm{SO}_{4}\right)$. The level of $\mathrm{Al}^{3+}$, indicating toxic acidity, was determined using $0.031 \mathrm{M}$ CDTA. Total CEC was determined using the small-exchange approach (SPAC, 1992), utilizing $\mathrm{BaCl}_{2}$ and Magnesium Sulfate. Organic $\mathrm{C}$ was determined using the wet digestion method, using potassium dichromate with external heat and back titration (Hesse, 1971). Organic matter was estimated by dividing OC values by the constant 1.724 (Mebius, 1960). All physical and chemical analyses were carried out using procedures set by SPAC (1992) and EMBRAPA (1997).

\section{Soil moisture and water level of inundation}

Soil moisture, or soil volumetric water content expressed as a percent (VWC), was measured adjacent to 24 randomly selected individuals during the wet and dry seasons of 2009 and 2010. Monthly readings were taken in each site for 4-6 months of each season, and a mean reading was obtained for each season, habitat, and individual. The VWC readings were taken at three equidistant $(1 \mathrm{~m})$ points from the palm, allowing us to calculate a mean VWC for that particular individual. We used a Campbell Scientific 616 Water Content Reflectometer (Campbell Scientific, Inc.), following methods of O'Brien and Oberbauer (2001). Probes of the reflectometer sensor penetrated $30 \mathrm{~cm}$ of the soil. When sites flooded during the wet season, we also measured the depth of water at three equidistant $(1 \mathrm{~m})$ points from sample individuals, and calculated a mean depth for that individual. Depth was measured using a meter tape, which we extended from the soil surface to the top of the water surface. 


\section{Photosynthetically Active Radiation}

In each habitat, the amount of photosynthetically active radiation (PAR) was measured at the tops of the crowns of individuals from which we collected fruit $(n=20)$. We used a home-built light sensor (Cournac et al. 2002) which provides a 180 degree integratedmeasure of the transmitted light in the PAR region $(400-750 \mathrm{~nm})$, read through a digital voltmeter. All readings were taken during cloudless periods between 1100 and 1300h. Our light sensor was calibrated using a pyranometer (LI-2005B, LICOR, USA).

\section{Vegetative biometrics}

We calculated the following vegetative biometrics for each tagged individual in each site: diameter at breast height (dbh), height, number of leaves, and crown volume. Height was defined as the distance to the top of the crown, and was measured using a clinometer (Suunto Instrument, Finland). Crown volume was calculated using the appropriate volumetric formula for a dome because a dome most accurately describes the shape of this palm's crown. We calculated the radius of the crown by measuring the mean of the maximum and minimum diameters and dividing by one half $\left[\left(\right.\right.$ diameter $_{\max } .+$ diameter $\left.\left._{\text {min. } .}\right) / 2 * 1 / 2\right]$.

\section{Statistical analysis}

Data for 2009 and data for 2010 were analyzed separately. The total number of fruits per individual was calculated by multiplying the total number of infructescences per individual and the total number of fruits per infructescence. The total number of seeds per individual was calculated by multiplying the total number of fruits per infructescence and the number of seeds per fruit. We used Analysis of Variance's (ANOVA's) to examine the relationship between habitat and fruit/ seed variables (number of seeds per fruit, seed 
mass per fruit, fruit mass, and fruit yield per individual, habitat and vegetative biometrics (height, diameter at breast height (dbh), number of leaves, and crown volume), and habitat and soil physical (\% sand, silt, and clay) or chemical ( $\mathrm{pH}$, exchangeable $\mathrm{Ca}^{2+}$, $\mathrm{Mg}^{2+}, \mathrm{K}^{+}$, and $\mathrm{Na}$, available $\mathrm{P}, \mathrm{Al}^{3+}$, total cation exchange capacity, $\%$ base saturation, $\%$ aluminum saturation, organic matter, and organic carbon) parameters. In each of these ANOVA's, we used habitat as the fixed factor, followed by Tukey's Honest Significant Difference (HSD) and Dunnett C pair-wise comparisons. Fruit yield (kg of fruit per individual) and crown volume were double-square root transformed because they did not meet normality requirements, and Dunnett C post-hoc tests were used assuming unequal variances. We also verified if a correlation existed between $\mathrm{dbh}$ and height. Mean VWC (\%) was calculated for each individual during the wet and dry seasons of 2009 and 2010, allowing us to obtain means for each habitat and particular season. The effect of habitat on soil moisture was tested using an ANOVA, followed by Tukey's HSD pair-wise comparisons. The same procedure was performed for flooding depth during the wet seasons of 2009 and 2010.

Photosynthetically Active Radiation (PAR) data were non-normally distributed and unsuccessfully transformed. A non-parametric Kruskal-Wallis test and Mann-Whitney pair-wise comparisons were performed to determine if PAR at the canopy of sample individuals differed significantly among habitats.

To determine which factors explain fruit and seed production, we conducted multiple linear regression analyses on each response variable (number of seeds, seed mass, fruit mass, and fruit yield per individual), using a Generalized Linear Model. We started each regression with 21 independent variables including vegetative biometrics, physical and 
chemical soil parameters, soil moisture (during the wet and dry seasons), and flooding depth. Photosynthetically active radiation was excluded from the analysis because means did not differ significantly among habitats. A backward regression was applied to the number of seeds and seed mass to select the best fit model, and the Enter method was used for fruit mass and fruit yields per individual. Correlations were also conducted between each response variable and the independent variables, as well as between independent variables. Final models of each regression contained no correlated independent variables. Analyses were separated by year because year significantly affected the relationship between variables when included in the regression. The final model for each response variable contained a maximum of four predictors.

All data were checked for normality before proceeding with parametric analyses, and a Holm's Sequential Bonferroni correction was applied to each pair-wise comparison to control for Type I error. All statistical analyses were performed in IBM SPSS Statistics versions 19 and 20 (SPSS, Chicago, Illinois, USA).

\section{RESULTS}

\section{Fruit and seed production}

Fruit and seed production varied significantly among habitats during each year. We observed a wide range of mass per seed (seed mass) and mass per fruit (fruit mass) within and among populations; seeds weighed between 0.2 and $26.6 \mathrm{~g}(N=835)$, and fruits weighed between 4.8 and $45.3 \mathrm{~g}(N=870)$. Seed mass and fruit mass differed significantly between years (seed mass: $F_{1,1438}=439.10, P<0.001$; fruit mass: $F_{1,1456}=$ 196.30, $P<0.001)$. During the first study year, the number of seeds per fruit and seed mass were significantly higher in the undisturbed savanna-ecotone and undisturbed forest 
than in the disturbed savanna, but seed number and seed mass did not differ significantly between the two undisturbed habitats. In contrast, seed number and seed mass were significantly higher in the forest than ecotone habitat during the second year (Fig. 2a, $2 b$ ). We found similar results for fruit mass during the first year; however, fruit mass was higher in the ecotone than in the forest during the second year (Fig. 2c). We found a different relationship for the total fruit $(\mathrm{kg})$ produced by each female. In 2009, females in the undisturbed habitats did not produce significantly different fruit yields $(\mathrm{kg})$, but fruit yields differed significantly between each of the undisturbed habitats and the disturbed savanna (Figure 2d). In 2010, fruit yields in the forest were significantly higher than in the ecotone. Seed size and seed number were positively correlated during both years (Yr. 1: $r=0.45, P<0.001$; Yr. $2: r=0.19, P<0.001)$. We found a large range in the mean number of fruits $( \pm S E)$ per female; $575.68( \pm 19.54)$ to $1324.18( \pm 32.06)$, and the mean total number of seeds per female $( \pm S E) ; 641.91( \pm 30.91)$ to $1384.83( \pm 51.11)$.

\section{Soil parameters}

Physical properties: Soil texture differed significantly among habitats, and this distinction remained constant between years (Table 1). Clay content was significantly highest in the disturbed savanna (Yr 1: $\left.F_{2,100}=26.53, P<0.001 ; \operatorname{Yr} 2: F_{2,177}=35.82, P<0.001\right)$. Silt content was highest in the undisturbed savanna ecotone (Yr 1: $F_{2,100}=21.40, P<0.001$; Yr 2: $\left.F_{2,177}=56.38, P<0.001\right)$. Sand was highest in the forest $\left(\right.$ Yr 1: $F_{2,100}=18.83, P<$ $0.001 ;$ Yr 2: $\left.F_{2,177}=20.13, P<0.001\right)$.

Chemical properties: Soil nutrients were highly variable among habitats and years (Table 1). Soils in all habitats were acidic and $\mathrm{pH}$ ranged from 4.98 to 5.22 . We found soil in the disturbed savanna to be the most acidic, and soil in the forest to be least acidic, although 
these differences were significant only during the second year $\left(F_{2,177}=10.23, P<0.001\right)$. The total exchangeable bases $(\mathrm{Ca}, \mathrm{Mg}, \mathrm{K}$, and $\mathrm{Na}$ ), or Sum of Bases, was significantly highest in the forest habitat, and significantly lowest in the disturbed savanna during both study years (Yr 1: $F_{2,100}=11.18, P<0.001 ;$ Yr 2: $\left.F_{2,177}=24.93, P<0.001\right)$. Available $\mathrm{Al}^{3+}$, a measure of toxic acidity, was significantly highest in the disturbed savanna during both years (Yr 1: $\left.F_{2,100}=40.59, P<0.001 ; \operatorname{Yr} 2: F_{2,177}=73.46, P<0.001\right)$. We found a significant difference in available $\mathrm{P}$ among habitats only during the second year; highest in the disturbed savanna and lowest in the undisturbed savanna ecotone $\left(F_{2,177}=9.76, P\right.$ $<0.001)$. Total CEC was significantly highest in the disturbed savanna and lowest in the forest, although the difference was significant only during the second year $\left(F_{2,177}=\right.$ 24.74, $P<0.001)$. Organic matter was also significantly highest in the disturbed savanna and lowest in the forest during the second year $\left(F_{2,177}=27.44, P<0.001\right)$. Results were the same for organic Carbon. Base saturation (V \%), indicating soil fertility, was significantly highest in the forest and lowest in the disturbed savanna during both study years $\left(F_{2,100}=23.28, P<0.001 ; F_{2,177}=96.84, P<0.001\right)$.

\section{Soil moisture and flooding}

Precipitation patterns varied between years; 2010 was an abnormally wet year.

Volumetric water content (VWC) differed significantly among habitats $\left(F_{2,794}=72.64, P\right.$ $<0.001)$ during the first year, but not during the second year $\left(F_{2,334}=0.18, P=0.67\right)$. We found a highly significant difference in VWC between the wet and dry seasons during the first year $\left(F_{1,794}=590.25, P<0.001\right)$, compared to a marginally significant difference during the second year $\left(F_{1,334}=5.09, P=0.03\right)$. 


\section{Photosynthetically Active Radiation}

The mean photosynthetically active radiation (PAR) reaching the tops of the crowns of Mauritia flexuosa in each habitat did not differ significantly among habitats $\left(\chi^{2}=1.49\right.$, $P>0.05)$.

\section{Vegetative biometrics}

Palm height differed significantly among habitats $\left(F_{2,371}=220.56, P<0.001\right)$, and all pairwise comparisons were significant. Individuals in the forest habitat were the tallest, and those in the disturbed savanna were the shortest (Fig. 3a). Diameter at breast height also differed significantly among habitats $\left(F_{2,371}=48.87, P<0.001\right)$, with all significant pairwise comparisons. Diameter was largest in the disturbed savanna, and smallest in the undisturbed ecotone (Fig. 3b). We found no significant relationship between height and $\operatorname{dbh}(r=-0.10, P>0.05)$. The number of leaves did not differ significantly among habitats $\left(F_{2,363}=2.05, P=0.13\right)$. Crown volume differed significantly among habitats $\left(F_{2,371}=24.90, P<0.001\right)$, with individuals in the forest having the largest crown, and those in the undisturbed savanna ecotone having the smallest. Only pairwise comparisons between the forest and ecotone, and forest and disturbed savanna were significant (Fig. 3c).

\section{Factors determining fruit and seed production}

Seed number was significantly explained by the following predictors in 2009: volumetric water content (VWC) during the wet season, dbh, and height. We found no predictors of seed number in 2010, however. In 2009, VWC wet was the only significant predictor of seed mass. In 2010, flooding depth and organic matter significantly predicted seed mass. In 2009, fruit mass was explained by height and VWC wet. We found no predictors of 
fruit mass in 2010, however. The only predictor that significantly explained total fruit yield $(\mathrm{kg})$ per female individual was number of leaves during 2009. The following year, four predictors significantly explained fruit yield: dbh, height, number of leaves, and VWC wet (Table 2).

\section{DISCUSSION}

\section{Habitat effects on fruit and seed set}

Habitat heterogeneity and fragmentation affect the reproductive success of plants (Aizen et al., 2002; Cranmer et al., 2011). In other species, there is ample evidence of lower seed and fruit set in disturbed habitats relative to undisturbed habitats (Jennersten, 1988; Aizen and Feinsinger, 1994; Cunningham, 2000; Liu and Koptur, 2003). Our results corroborate previous findings; seed number, seed mass, and fruit mass were significantly lower in the disturbed savanna than in the undisturbed savanna ecotone and forest. Low fruit and seed set are typically attributed to inbreeding depression, caused by pollen limitation (Burd, 1994). Reduced habitat and resources for pollinators decrease pollinator diversity and pollination effectiveness (Wilcock and Neiland, 2002). However, we have no evidence of pollen limitation in any of the three habitats (Khorsand Rosa and Koptur, 2013). Contrary to what we expected, females in the disturbed savanna produced significantly higher fruit yields ( $\mathrm{kg}$ of fruit per individual) than those in the undisturbed habitats. Wind-pollination may explain this anomaly. Potentially reduced pollinator diversity caused by habitat fragmentation and the presence of the exotic species, Acacia mangium, does not seem to directly affect fruit production of $M$. flexuosa. However, disturbance may have profound implications for the pollination of other biotically pollinated native plants in Roraima. 
Interestingly, we did not find evidence of a trade-off between seed number and seed size, as has been suggested for other plants (Armstrong and Westoby, 1993; Jakobsson and Eriksson, 2000). The absence of trade-off may be explained by the low seed number typically produced in Mauritia flexuosa fruits. Generally, fruits contain one seed (the mean number of seeds in our study ranged from 1.01 to 1.21 ), so the trade-off between seed quantity and size may not be as relevant as in species with multi-seeded fruits.

It is worth noting the large amount of variation in mass per fruit and mass per seed observed within and among populations. Variability in seed mass has profound ecological implications including seed germination and dispersal, as well as seedling establishment and survival (Wulff, 1986). Heavy seeds have larger food reserves and establish more quickly than light seeds (Salisbury, 1942). Large variation in seed mass has been found in other plants (McWilliams et al., 1968; Baker, 1972; Ågren, 1989), and highlights the role of both genetic and environmental factors in determining seed size variability and consequential germination.

Baker (1972) found a positive correlation between seed mass and moisture stress in 2500 taxa of California plants. Seedlings that surviving xeric stress were more likely to have originated from heavy seeds than light seeds. In our study, seed mass in the undisturbed savanna ecotone and forest was significantly higher during the first, drier year than the second, wetter year. The female plant may invest in heavy seeds in dry conditions to increase the probability of seed germination and seedling survival. Fruit mass indirectly reflects seed mass, as larger fruits tend to produce larger seeds. Although two years of data are not sufficient to draw conclusions, it is possible that selection has acted such that in response to drought, females allocate resources to increased seed mass 
compared to seed mass under wet conditions. Alternatively, large seeds size in dry years may be a consequence of physiological response such as increased fruit abortion, leaving more resources spread among fewer fruits. A future long-term study should investigate the relationship between rainfall and seed mass.

Role of abiotic and biotic factors in fruit and seed production

Soil volumetric water content, or soil moisture, during the wet season was the most important factor in explaining seed number and mass. Flooding depth also seems to play a role in seed output, although flooding may be more relevant than soil moisture during abnormally wet seasons, as observed in 2010 . Similar to results for seed set, soil moisture during the wet season appears to drive variation in fruit mass and yields; soil moisture was the only abiotic factor responsible for variation observed in fruit production.

Thus, it appears that rainfall, especially during the wet season, is an important driver of seed production in M. flexuosa. Fruit and seed maturation in this species occurs during the wet season in Roraima (Khorsand Rosa, unpubl. data), highlighting the crucial role that soil moisture during the rainy season plays in fruit and seed development. In the southern Amazon, rainfall explained a significant amount of variation in seed production of Carapa guianensis, although rainfall during the dry season was more critical than during the wet season (Klimas et al. 2012).

In contrast to soil moisture and flooding, soil nutrients do not appear to play a determinant role in seed production of M. flexuosa. Only organic matter explained a significant amount of variation in seed mass during the second year. Organic matter is one of the most important components of tropical soils, functioning as a reserve of nitrogen and contributing to chemical and biological processes, which are directly related 
to productivity (Craswell and Lefroy, 2001). Amazonian soils are typically deficient in organic matter as a result of high rainfall, leaching, and low nutrient retention (van Wambeke, 1992; Lehmann et al., 2003). Very low organic matter $(<2 \%)$ has been reported in other studies in Roraima (Benedetti et al., 2011). Our results (> 3\%) suggest that soils in our sites are relatively high in organic matter. San José et al. (2010) found that soils dominated by M. flexuosa sequestered significant amounts of carbon, directly related to organic matter. Thus, dense populations of $M$. flexuosa produce vegetative matter that accumulates on the soil floor, increasing soil organic matter and fertility. Although all three habitats, especially disturbed savanna, demonstrated high aluminum toxicity, this factor does not seem to affect reproductive output in M. flexuosa. High aluminum toxicity typically characterizes acidic, nutrient deficient soils, common in the open savanna, or cerrado (Goodland, 1971). Native species of the cerrado tolerate aluminum toxic, acidic soils; these species accumulate, rather than exclude aluminum, to aid in vegetative and reproductive growth (Haridasan, 2008). In the neighboring Gran Sabana of Venezuela, Olivares et al. (2010) found Melastomataceae species with high accumulations of aluminum growing in a Mauritia swamp. Although the role of aluminum in the metabolism of M. flexuosa has not yet been established, this palm most likely accumulates aluminum, like other species growing in the savanna.

Though clearly differing among habitats, soil type does not seem to significantly influence seed output in M. flexuosa. Hammond and Brown (1995) also found no significant relationship between soil type and seed size in neotropical woody species. Although soil texture may vary slightly temporally as a result of variation in short-term precipitation and weathering patterns, soil texture remains stable in comparison with soil 
moisture. Slight temporal variation in soil texture may just be a result of spatial variation in sampling. Thus, highly variable soil moisture may play a more determinant role in seed output than soil type.

Vegetative biometrics as predictors of reproductive biomass

Vegetative and reproductive allocation are closely related, especially in dioecious plants where females must invest in both flower and fruit production (Gross and Soule, 1981). Access to resources and optimal environmental conditions increase growth, allowing for greater reproductive investment. Plant size is a good estimator of reproductive investment (Horvitz and Schemske, 2002). In woody plants, dbh is an indicator of plant size, and both are indicators of fruit crop (Peters et al., 1988; Chapman et al., 1992). The relationship between plant size and fecundity in palms remains less clear, however. Palms, containing one apical meristem, do not consistently follow the same $\mathrm{dbh} /$ height correlation observed in plants with multiple apical meristems. An invariant relationship was determined between fecundity and size in Cocos nucifera (Watkinson and White, 1986), while a positive correlation between the two factors was found in Astrocaryum mexicanum and Rhopalostylis sapida (Piñero \& Sarukhán, 1982; Enright, 1992). Furthermore, palm dbh is established during the seedling phase, before the palm grows in height, referred to as primary thickening (Henderson, 2002). Our results suggest a positive relationship between fruit yield and dbh, and a negative relationship between fruit yield and height. Thus, abiotic conditions early during seedling establishment growth may explain fruit yield later when the seedling becomes an adult. However, testing this hypothesis is beyond the scope of this paper, as it requires a longterm study initiated at seedling stage and lasting through fruiting maturity. 
The most important vegetative biometric determining fruit yield in this species appears to be the number of leaves. Photosynthate produced by leaves is directed towards development of fruits (Murren and Ellison, 1996). Contrary to leaf number, dbh, and height, crown volume was not a good predictor of fruit crop in $M$. flexuosa. Our results corroborate those found by Chapman et al. (1992) in woody, neotropical trees.

Abiotic conditions and vegetative biometrics in the disturbed savanna may partly explain why fruit yield was unexpectedly higher than in the undisturbed ecotone or forest. Acacia mangium may strongly influence the soil fertility in this habitat by fixing nitrogen (Galiana et al., 2002). Although we did not measure nitrogen, it is possible that increased levels of this nutrient promote an increase in fruit yield in $M$. flexuosa. Nitrogen may also be directly linked to the number of leaves, explaining variation in fruit yield. The high levels of organic matter found in the disturbed savanna habitat may also play a role in fruit yields. However, our results suggest that vegetative attributes affect fruit production more than soil parameters.

\section{Influence of climatic variation on reproductive output}

Considerable variation in fruit yield, caused by local abiotic conditions and seasonality, is common among populations and years (Ågren et al., 2008). Although environmental and vegetative factors clearly determine reproductive output of Mauritia flexuosa, short-term climatic variation may also have a strong influence. Plant communities respond to seasonal climatic variation (Clark and Clark, 1994). Ecotonal habitats may be especially sensitive to inter-annual changes in climate patterns (Goulart et al., 2011; Mayle et al., 2007). The first year of our study (2009-2010) was an E1 Niño Southern Oscillation (ENSO) year, characterized by temperature increase and decreased 
rainfall in the northern Amazon (Li et al., 2011; Yoon \& Zeng, 2010). The following year was an atypically cold, wet year (NOAA, 2013). Thus, it makes sense that soil moisture during the wet season of year one explained more variation in seed number, seed mass, and fruit mass, than during year two. Given that rainfall and soil moisture play such an important role in fruit and seed production of M. flexuosa, perhaps the strong inter-annual variation in precipitation permitted females in the undisturbed forest and savanna ecotone to increase fruit yields during the second year. Giraldo (1987) reported significant yearto-year variation in fruit production of M. flexuosa in Colombia. Wheelright (1986) also found that in many Lauraceae species of Costa Rica, the same populations produced significantly different fruit yields from year to year. Thus, previous fruit production may not be an accurate predictor of future fruit production. Temporal variation in precipitation patterns also affects vegetative growth, and consequently, reproductive growth.

Therefore, long-term studies are necessary so we can distinguish meaningful changes in climate patterns from short-term variation, and predict its effect on plant reproductive dynamics.

\section{Mauritia flexuosa as a NTFP}

Our results show that habitat and climate affect fruit yields. These results are relevant to NTFP managers and harvesters. In a single-habitat study in Roraima, Barbosa et al. (2010) reported a mean of $62.2 \mathrm{~kg}$ of fresh fruits per female. The mean production of fresh fruits $(\mathrm{kg})$ per female in our study ranged from $29.18( \pm 4.91) \mathrm{kg}$ to $100.15( \pm$ 26.40) $\mathrm{kg}$, corroborating the previous study's results, although our results may be more informative as they take season and habitat into consideration. Yields in Roraima may be low compared to other regions in the Amazon. Studies from the Peruvian Amazon report 
higher yields (138 kg per individual, Ruiz et al., 2010; $190 \mathrm{~kg}$ per individual, Bohorquez, 1976). Current yields in Peru may be lower, however, as overharvesting may reduce fecundity of females (Delgado et al., 2007). Nevertheless, the abiotic conditions such as soil and micro- climate of each region are likely to explain inter-regional differences in yields of M. flexuosa, and must be considered when evaluating NTFP potential.

The quantity of oil that can be produced from fresh M. flexuosa fruits, or buriti, is also important for NTFP markets. Buriti oil can be used as a nutritional supplement and in cosmetics (Zanatta et al., 2008; Silva et al., 2009), as well as in the production of biodiesel and plastics (Schlemmer et al., 2007; Andrade et al., 2012). We cannot calculate the quantity of oil produced in each habitat because we did not specifically weigh the pulp or mesocarp of each sampled fruit. However, Ferreira (2008) estimates that $1000 \mathrm{~kg}$ of fresh fruit produce $45 \mathrm{~kg}$ of oil. On the basis of this estimate, harvesters in our sites would need to collect fruits from approximately 10 to 30 females to produce $45 \mathrm{~kg}$ of oil. In each $200 \times 20 \mathrm{~m}$ transect, we counted 20 to 38 females. Thus, each site could potentially produce 45 to $90 \mathrm{~kg}$ of oil. In the savanna of Roraima, Barbosa et al. (2010) estimates $57.5 \pm 17.0 \mathrm{~kg}$ of buriti oil per hectare per year, and comments that this amount is low compared to other oil fruits of Brazil. Oil yields are higher for other fruits of the Amazon such as Astrocaryum vulgare and Bactris gasipaes, and cultivated species such as Elaeis guineensis (Johnson, 1985), suggesting that buriti may be more effectively sold as a fruit for consumption rather than processed for biodiesel. Tall palms such as $M$. flexuosa are generally not efficient oil crops (R. Campbell, pers. comm.). 


\section{Conclusions}

Fruit and seed production of Mauritia flexuosa varied significantly among habitats. Fruit mass and seed mass/ seed number were higher in the undisturbed savanna ecotone and forest than in the disturbed savanna. Contrary to what we expected, fruit yield was highest in the disturbed savanna. Soil moisture and flooding during the wet season are the most important factors in explaining variation in fruit and seed output, although flooding plays a less significant role. Soil organic matter also is an important determinant of seed mass. Other soil parameters including texture, available nutrients, and toxicity do not significantly explain reproductive output. Vegetative biometrics, namely the number of leaves, dbh, and height are accurate predictors of reproductive output. Crown volume, however, should not be used to estimate fruit yields. Inter-annual variation in precipitation most likely plays a strong role in fruit and seed production, although longterm studies are needed to confirm this hypothesis with certainty.

\section{ACKNOWLEDGMENTS}

The authors thank L. Noblick and N.M.B. Rosa for assisting with tree-climbing and equipment, and Brazilian field assistants, F. Guedes, K.B. Ferreira, and I.S. Firmino, for collecting data. The National Science Foundation (Award No. 0906083), Fulbright-Hayes Commission, National Institute for Research in Amazonia (INPA), International Palm Society, and Montgomery Botanical Center provided funding. Completion of this manuscript was in part supported by a Dissertation Year Fellowship from Florida International University. Access to field sites was granted from the Brazilian Ministry of the Environment (MMA) (Permits 18307-1 and 22967-1). D. Bray, R. Campbell, M. Donnelly, S. Oberbauer, and S. Zona greatly improved the manuscript; P. Johnson 
provided statistical assistance; and D. Gann created the map of field sites. Maracá Ecological Reserve, Chico Mendes Biodiversity Institute, and INPA provided logistical support. 


\section{LITERATURE CITED}

Ågren J. 1989. Seed size and number in Rubus chamaemorus: between-habitat variation, and effects of defoliation and supplemental pollination. Journal of Ecology 77: $1080-1092$.

Ågren J, Ehrlén J, Solbreck C. 2008. Spatio-temporal variation in fruit production and seed predation in a perennial herb influenced by habitat quality and population size. Journal of Ecology 96: 334-345.

Aizen MA, Feinsinger P. 1994. Forest fragmentation, pollination, and plant reproduction in a chaco dry forest, Argentina. Ecology 75: 330-351.

Aizen MA, Ashworth L, Galetto L. 2002. Reproductive success in fragmented habitats: do compatibility systems and pollination specialization matter? Journal of Vegetation Science 13: 885-892.

Armstrong DP, Westoby M. 1993. Seedlings from large seeds tolerated defoliation better: a test using phylogeneticaly independent contrasts. Ecology 74: 10921100 .

Baker HG. 1972. Seed weight in relation to environmental conditions in California. Ecology 53: 997-1010.

Barbosa RI, Mourão Jr. M., Casadio GML, Silva SJR. 2012. Reproductive phenology of the main tree species in the Roraima savanna, Brazilian Amazon. Ecotropica 18: in press.

Barbosa RI, Lima AD, Mourão Jr. M. 2010. Biometria de frutos do buriti (Mauritia flexuosa L. f.- Arecaceae): Producão de polpa e óleo em uma área de savana em Roraima. Amazônia: Ciência e Desenvolvimento 5: 71-85.

Barbosa RI, Fearnside PM. 2005. Fire frequency and area burned in the Roraima savannas of Brazilian Amazonia. Forest Ecology and Management 204: 371-384.

Brokamp G, Valderrama N, Mittelbach M, Grandez CA, Barfod AS, Weigend M. 2011. Trade in palm products in north-western South America. Botanical Review 77: 571-606.

Benedetti UG, do Vale Júnior JF, Schaefer CEG, Melo VF, Uchôa SCP. 2011. Gênese, química e mineralogia de solos derivados de sedimentos pliopleistocênicos e de rochas vulcânicas básicas em Roraima, norte Amazônico. Revista Brasileira de Ciência do Solo 35:299-312.

Brightsmith DJ. 2005. Parrot nesting in southeastern Peru: seasonal patterns and keystone trees. Wilson Bulletin 117: 296-305.

Burd M. 1994. Bateman's principle and plant reproduction: the role of pollen limitation in fruit and seed set. The Botanical Review 60: 84-112. 
Caillaud D, Crofoot MC, Scarpino SV, Jansen PA, Garzon-Lopez CX, Winkelhagen AJS, Bohlman SA, Walsh PD. 2010. Modeling the spatial distribution and fruiting pattern of a key tree species in a Neotropical forest: methodology and potential applications. PLOS One 5: e15002.

Chapman CA, Chapman LJ, Wangham R, Hunt K, Gebo D, Gardner L. 1992. Estimators of fruit abundance of tropical trees. Biotropica 24: 527-531.

Clark DA, Clark DB. 1994. Climate-induced annual variation in canopy tree growth in a Costa Rican tropical rain forest. Journal of Ecology 82:865-872.

Cournac L, Dubois MA, Chave J, Riera B. 2002. Fast determination of light availability and leaf area index in tropical forests. Journal of Tropical Ecology 18: 295-302.

Cousens RD, Hill J, French K, Bishop ID. 2010. Towards better prediction of seed dispersal by animals. Functional Ecology 24:1163-1170.

Cranmer L, McCollin D, Ollerton J. 2011. Landscape structure influences pollinator movements and directly affects plant reproductive success. Oikos 121: 562-568.

Craswell ET, Lefroy RDB. 2001. The role and function of organic matter in tropical soils. Nutrient Cycling in Agroecosystems 61: 7-18.

Cunningham SA. 2000. Depressed pollination in habitat fragments causes low fruit set. Proceedings of the Royal Society London, B 267: 1149-1152.

Delgado C, Couturier G, Mejia K. 2007. Mauritia flexuosa (Arecaceae: Calamoideae), an Amazonian palm with cultivation purposes in Peru. Fruits 62: 157-169.

EMBRAPA, Empresa Brasileira de Pesquisa Agropecuária. 1997. Manual de métodos de análise de solo, $2^{a}$ edição. Rio de Janeiro: EMBRAPA- CNPS.

Enright NJ. 1992. Factors affecting reproductive behavior in the New Zealand nikau palm, Rhopahlostylis sapida Wendl. et Drude. New Zealand Journal of Botany 30: $69-80$.

Foster SA. 1986. On the adaptive value of lrge seeds for tropical moist forest trees: a review and synthesis. Botanical Review 52: 260-299.

Galiana A, Balle P, N'Guessan Kanga A, Domenach AM. 2002. Nitrogen fixation estimated by the ${ }^{15} \mathrm{~N}$ natural abundance method in Acacia mangium Willd. inoculated with Bradyrhizobium sp. and grown in silvicultural conditions. Soil Biology and Biochemistry 34: 251-262.

Gee GW, Bauder JW. 1986. Particle-size analysis. In: Klute A, ed. Methods of Soil Analysis. Part 1. Physical and Mineralogical Methods. Madison: ASA-SSSA, 383-411. 
Giraldo LEU. 1987. Estudio preliminar de la fenología de la canangucha (Mauritia flexuosa L.f.). Colómbia Amazónica 2:57-81.

Goodland R. 1971. A physiognomic analysis of the cerrado vegetation of central Brazil. Journal of Ecology 59: 411-419.

Goulart MF, Lovato MB, de Vasconcellos Barros F, Valladares F, Lemos-Filho JP. 2011. Which extent is plasticity to light involved in ecotypic differentiation of a tree species from savanna and forest? Biotropica 43: 695-703.

Goulding M, Smith N. 2007. Palms, sentinels for amazon conservation. St. Louis: Amazon Conservation Association, Missouri Botanical Garden Press.

\section{Greenberg CH, Levey DJ, Kwit C, Mccarty JP, Pearson SF, Sargent S, Kilgo J.} 2012. Long-term patterns of fruit production in five forest types of the South Carolina upper coastal plain. Journal of Wildlife Management 76:1036-1046.

Gross KL. 1984. Effects of seed size and growth form on seedling establishment of six monocarpic perennial plants. Journal of Ecology 72:369-387.

Gross KL, Soule JD. 1981. Differences in biomass allocation to reproductive and vegetative structures of male and female plants of a dioecious, perennial herb, Silene alba (Miller) Krause. American Journal of Botany 68:801-807.

Hammond DS, Brown VK. 1995. Seed size of woody plants in relation to disturbance, dispersal, and soil type in wet neotropical forests. Ecology 76: 2544-2561.

Hampe A. 2008. Fruit tracking, frugivore satiation, and their consequences for seed dispersal. Oecologia 156: 137-145.

Haridasan M. 2008. Nutritional adaptations of native plants of the cerrado biome in acid soils. Brazilian Journal of Plant Physiology 20: 183-195.

Hartshorn GS. 1995. Ecological basis for sustainable development in tropical forests. Annual Review of Ecology and Systematics 26:155-175.

Henderson A. 2002. Evolution and ecology of palms. New York: New York Botanical Garden Press.

Henderson A. 1995. The palms of the Amazon. New York: Oxford University Press.

Henry O, Feer F, Sabatier D. 2000. Diet of the Lowland Tapir (Tapirus terrestris L.) in French Guiana. Biotropica 32: 364-368.

Herrera CM. 1985. Habitat-consumer interactions in frugivorous birds. In: Cody, M. (ed.), Habitat selection in birds. Orlando: Academic Press, 341-365. 
Hesse PR. 1971. Soil chemical analysis. Chemical Publishing Co., New York.

Holm JA, Miller CJ, Cropper WP. 2008. Population dynamics of the dioecious Amazonian palm Mauritia flexuosa: simulation analysis of sustainable harvesting. Biotropica 40: 550-558.

Horn CM, Gilmore MP, Endress BA. 2012. Ecological and socio-economic factors influencing aguaje (Mauritia flexuosa) resource management in two indigenous communities in the Peruvian Amazon. Forest Ecology and Management 267: 93103.

Horvitz CC, Schemske DW. 2002. Effects of plant size, leaf herbivory, local competition and fruit production on survival, growth and future reproduction of a neotropical herb. Journal of Ecology 90:279-290.

Howe HF, Smallwood J. 1982. Ecology of seed dispersal. Annual Review of Ecology and Systematics 13:201-228.

Jakobsson A, Eriksson O. 2000. A comparative study of seed number, seed size, seedling size and recruitment in grassland plants. Oikos 88: 494-502.

Jennersten O. 1988. Pollination in Dianthus deltoides (Caryophyllaceae): effects of habitat fragmentation on visitation and seed set. Conservation Biology 2: 359366.

Khorsand Rosa R, Koptur S. 2013. New findings on the pollination biology of Mauritia flexuosa (Arecaceae) in Roraima, Brazil: linking dioecy, wind, and habitat. American Journal of Botany 100:613-621.

Klimas CA, Kainer KA, Wadt LH, Staudhammer CL, Rigamonte-Azevedo V, Freire Correia M, da Silva Lima LM. 2012. Control of Carapa guianensis phenology and seed production at multiple scales: a five year study exploring the influences of tree attributes, habitat heterogeneity and climate cues. Journal of Tropical Ecology 28:105-118.

Köppen W. 1936. Das geographisca system der climate. In: Köppen, W, and Geiger, G, eds. Handbuch der klimatologie. Berlin: Gebrüder Borntraeger, 1-44.

Lehmann J, da Silva Jr. JP, Steiner C, Nehls T, Zech W, Glaser B. Nutrient availability and leaching in an archaeological anthrosol and a ferralsol of the Central Amazon Basin: fertilizer, manure and charcoal amendments. Plant and Soil 249: 343-357. 
Leishman MR, Wright IJ, Moles AT, Westoby M. 2000. The evolutionary ecology of seed size. In: Fenner M, ed. Seeds: the ecology of regeneration in plant communities, 2nd edn. New York: CABI Publishing, 31-45.

Li W, Zhang P, Ye J, Li L, Baker PA. 2011. Impact of two different types of El Niño events on the Amazon climate and ecosystem productivity. Journal of Plant Ecology 4:91-99.

Liu H, Koptur S. 2003. Breeding system and pollination of a narrowly endemic herb of the lower Florida Keys: impacts of the urban-wildland interface. American Journal of Botany 90: 1180-1187.

Loiselle BA, Blake JG. 1991. Temporal variation in birds and fruits along an elevational gradient in Costa Rica. Ecology 72:180-193.

Manzi M, Coomes OT. 2009. Managing Amazonian palms for community use: a case of aguaje palm (Mauritia flexuosa) in Peru. Forest Ecology and Management 257: 510-517.

Mayle FE, Langstroth RP, Fisher RA, Meir P. 2007. Long-term forest-savannah dynamics in the Bolivian Amazon: implications for conservation. Philosophical Transactions of the Royal Society of London, Series B 362:291-307.

McLane SC, Aitken SN. 2012. Whitebark pine (Pinus albicaulis) assisted migration potential: testing establishment north of the species range. Ecological Applications 22: 142-153.

McWilliams EL, Landers RQ, Mahlstede JP. 1968. Variation in seed weight and germination in populations of Amaranthus retroflexus L. Ecology 49: 290-296.

Mebius LJ. 1960. A rapid method for the determination of organic carbon in soil. Analytica Chimica Acta 22: 120-124.

Menke S, Böhning-Gaese K, Schleuning M. 2012. Plant-frugivore networks are less specialized and more robust at forest-farmland edges than in the interior of a tropical forest. Oikos 121: 1553-1566.

Miller KE, Dietz, JM. 2004. Fruit yield, not dbh or fruit crown volume, correlates with time spent feeding on fruits by wild Leontopithecus rosalia. International Journal of Primatology 25: 27-39.

Murren CJ, Ellison AM. 1996. Effects of habitat, plant size, and floral display on male and female reproductive success of the neotropical orchid Brassavola nodosa. Biotropica 28: 30-41. 
Nathan R, Schurr FM, Spiegel O, Steinitz O, Trakhtenbrot A, Tsoar A. 2008. Mechanisms of long-distance seed dispersal. Trends in Ecology and Evolution 23: $638-647$.

National Oceanic and Atmospheric Administration (NOAA). 2013. Cold and warm episodes by season.

http://www.cpc.ncep.noaa.gov/products/analysis monitoring/ensostuff/ensoyears. $\underline{\text { shtml }}$

O'Brien JJ, Oberbauer, SF. 2001. An inexpensive, portable method for measuring soil moisture. Soil Science Society of America Journal 65:1081-1083.

Olivares E, Colonnello G, Peña E, Rodriguez L. 2010. Aluminum accumulation in nineteen Melastomataceae species from three contrasting plant formations in acid soils. Journal of Plant Nutrition and Soil Science 173: 453-460.

Peters RH, Clontier S, Dubé Evans A, Hastings P, Kaiser H, Kohn D, Sarwer-Foner B. 1988. The allometry of the weight of fruit on trees and shrubs in Barbados. Oecologia 74: 612-616.

Piñero D, Sarukhán J. 1982. Reproductive behaviour and its individual variability in a tropical palm, Astrocaryum mexicanum. Journal of Ecology 70: 461-472.

Rodríguez-Pérez J, Wiegand T, Traveset A. 2012. Adult proximity and frugivore's activity structure the spatial pattern in an endangered plant. Functional Ecology 26:1221-1229.

Salisbury EJ. 1942. The reproductive capacity of plants; studies in quantitative biology. London: Bell.

Santos LMP. 2005. Nutritional and ecological aspects of buriti or aguaje (Mauritia flexuosa Linnaeus filius): A carotene-rich palm fruit from Latin America. Ecology and Food Nutrition 44: 345-358.

Silva SM, Sampaio KA, Taham T, Rocco SA, Ceriani R, Meirelles AJA. 2009. Characterization of oil extracted from buriti fruit (Mauritia flexuosa) grown in the Brazilian Amazon region. Journal of American Oil Chemist Society 86: 611-616.

SPAC, Soil and Plant Analysis Council, Inc. 1992. Reference methods for soil analysis. Athens: University of Georgia Press.

Ticktin T. 2004. The ecological implications of harvesting non-timber forest products. Journal of Applied Ecology 41:11-21.

van Wambeke A. 1992. Soils of the Tropics. New York: McGraw-Hill, 343 pp. 
Warren II RJ, Volker B, Bradford MA. 2012. The interaction between propagule pressure, habitat suitability and density-dependent reproduction in species invasion. Oikos 121: 874-888.

Watkinson AR, White J. 1986. Some life-history consequences of modular construction in plants. Philosophical Transactions of the Royal Society of London, Series B 313: $31-51$.

Wheelwright NT. 1986. A seven-year study of individual variation in fruit production in tropical bird-dispersed tree species in the family Lauraceae. In: Estrada A, Fleming TH, eds. Frugivores and seed dispersal. Dordrecht: Junk Publishers, 1935.

Wilcock C, Neiland R. 2002. Pollination failure in plants: why it happens and when it matters. Trends in Plant Science 7: 270-277.

Winn AA. 1985. Effects of seed size and microsite on seedling emergence of Prunella vulgaris in four habitats. Journal of Ecology 73: 831-840.

Wulff RD. 1986. Seed size variation in Desmodium paniculatum. Journal of Ecology 74: 87-97.

Yoon JH, Zeng EN. 2010. An Atlantic influence on Amazon rainfall. Climate Dynamics 34: 249-264.

Zanatta CF, Mitjans M, Urgatondo V, Rocha-Filho A, Vinardell MP. 2010. Photoprotective potential of emulsions formulated with Buriti oil (Mauritia flexuosa) against UV irradiation on keratinocytes and fibroblasts cell lines. Food and Chemical Toxicology 48: 70-75. 
TABLE 1. Mean physical and chemical soil parameters for each habitat and year, where

UE is undisturbed ecotone, UF is undisturbed forest, and DS is disturbed savanna; and

where clay, silt, and sand are $\%$ of total, $\mathrm{SB}$ is sum of bases $\left(\mathrm{cmol}_{\mathrm{c}} / \mathrm{dm}^{3}\right), \mathrm{Al}^{3+}$ is

available aluminum $\left(\mathrm{cmol}_{\mathrm{c}} / \mathrm{dm}^{3)}, \mathrm{CEC}\right.$ is total cation exchange capacity $\left(\mathrm{cmol}_{\mathrm{c}} / \mathrm{dm}^{3}\right)$,

$\mathrm{OM}$ is organic matter (\%), OC is organic carbon (\%), and $\mathrm{V}$ is base saturation (\%); and

where $* *$ indicates significance among habitats at $\mathrm{p}<0.001$.

\begin{tabular}{|c|c|c|c|c|c|c|c|c|c|c|c|c|}
\hline Yr & Hab & Clay & Silt & Sand & $\mathbf{p H}$ & $\mathbf{S B}$ & $\mathbf{A l}^{3+}$ & $\mathbf{P}$ & $\mathbf{C E C}$ & $\mathbf{O M}$ & $\mathbf{O C}$ & $\mathbf{V}$ \\
\hline 1 & UE & 8.68 & $29.62^{* *}$ & 61.71 & 5.10 & 0.92 & 0.54 & 4.23 & 6.07 & 3.03 & 1.76 & 14.76 \\
\hline 1 & UF & 3.84 & 13.35 & $82.81^{* *}$ & 5.12 & $2.40^{* *}$ & 0.28 & 4.56 & 5.59 & 3.01 & 1.75 & $35.98^{* *}$ \\
\hline 1 & DS & $17.66^{* *}$ & 16.44 & 65.91 & 4.98 & 0.60 & $1.08^{* *}$ & 4.40 & 6.89 & 3.33 & 1.93 & 9.91 \\
\hline 2 & UE & 10.17 & $37.63^{* *}$ & 52.2 & 5.07 & 0.53 & 0.63 & 2.87 & 4.86 & 3.34 & 1.93 & 10.65 \\
\hline 2 & UF & 5.42 & 22.45 & $70.47^{* *}$ & 5.22 & $0.72^{* *}$ & 0.31 & 4.40 & 3.69 & 2.26 & 1.31 & $19.71^{* *}$ \\
\hline 2 & DS & $17.48^{* *}$ & 17.20 & 65.32 & $5.01^{* *}$ & 0.35 & $0.94^{* *}$ & $5.04^{* *}$ & $6.14^{* *}$ & $3.56^{* *}$ & $2.07^{* *}$ & 6.51 \\
\hline
\end{tabular}


TABLE 2. Regression equations showing predictors for each response variable: number of seeds per fruit, seed dry mass $(\mathrm{g})$ per fruit, fruit dry mass $(\mathrm{g})$, and total fruit yield $(\mathrm{kg}$ of fruit) per female individual of Mauritia flexuosa during 2009 and 2010, in Roraima, Brazil; where dbh is diameter at breast height, ht. is total height of the palm (including crown), no. lvs. is number of leaves in the crown, VWC (wet) is volumetric water content during the wet season, and depth is flooding depth during the wet season; and where * of $P$ indicates significance of regression equation at $P<0.05$, and $* *$ indicates significance at $P<0.01$, and $N S$ indicates not significant; and where * in the regression equation indicates significance of predictor at $p<0.05$.

\begin{tabular}{|c|c|c|c|c|c|}
\hline Year & Resp. Var. & $R^{2}$ & $F$ & $P$ & Regression Equation \\
\hline 1 & $\begin{array}{l}\text { Seed } \\
\text { number }\end{array}$ & 0.55 & 10.86 & $<0.001 * *$ & $\begin{array}{l}\mathrm{y}=1.11-0.01(\mathrm{dbh}) *+0.01(\mathrm{ht} .)^{*}+0.01(\mathrm{VWC} \\
\text { wet })^{*}\end{array}$ \\
\hline 1 & Seed mass & 0.35 & 5.07 & $0.006 * *$ & $\begin{array}{l}\mathrm{y}=2.35+0.08 \text { (ht.) }+0.14 \text { (VWC wet)* }+0.002 \\
(\text { depth }) .\end{array}$ \\
\hline 2 & Seed mass & 0.70 & 9.28 & $0.002 * *$ & $\begin{array}{l}\mathrm{y}=2.83-0.15 \text { (ht.) }+1.64 \text { (organic matter)* }+ \\
0.42(\text { depth })^{*} .\end{array}$ \\
\hline 1 & Fruit mass & 0.37 & 5.32 & 0.005 & $\begin{array}{l}\mathrm{y}=4.54+0.33 \text { (ht.) })^{*}+0.35 \text { (no. lvs.) }+0.20 \\
(\text { VWC wet) } *\end{array}$ \\
\hline 1 & Fruit yield & 0.37 & 5.10 & 0.006 & $\begin{array}{l}\mathrm{y}=-103.48+3.28(\mathrm{dbh})-1.81 \text { (ht.) }+8.72 \text { (no. } \\
\text { lvs.)* }\end{array}$ \\
\hline 2 & Fruit yield & 0.78 & 8.93 & 0.002 & $\begin{array}{l}\mathrm{y}=-595.85+8.49(\mathrm{dbh})^{*}-4.23(\mathrm{ht} .)^{*}+14.45 \\
(\text { no. lvs. })^{*}+6.18(\mathrm{VWC} \text { wet })^{*}\end{array}$ \\
\hline
\end{tabular}


FIG. 1. Map of study area in Roraima, Brazil. Sites 1 and 2 comprise savanna ecotone habitat; sites 3 and 4 comprise forest habitat; and sites 5 and 6 comprise disturbed savanna habitat. Sites 1 through 4 are located at Maracá Ecological Reserve (MER). Sites 5 and 6 are located at Núcleo Jacitara, within Acacia mangium plantations. Forest vegetation category includes primary and secondary forest. Given coarse resolution of vegetation cover $(1 \mathrm{~km})$, savanna enclaves on MER appear as forest. Dark clumps represent sampled trees in each site. Source: Global Land Cover 2000 by the Global Vegetation Monitoring Unit of the Joint Research Center.

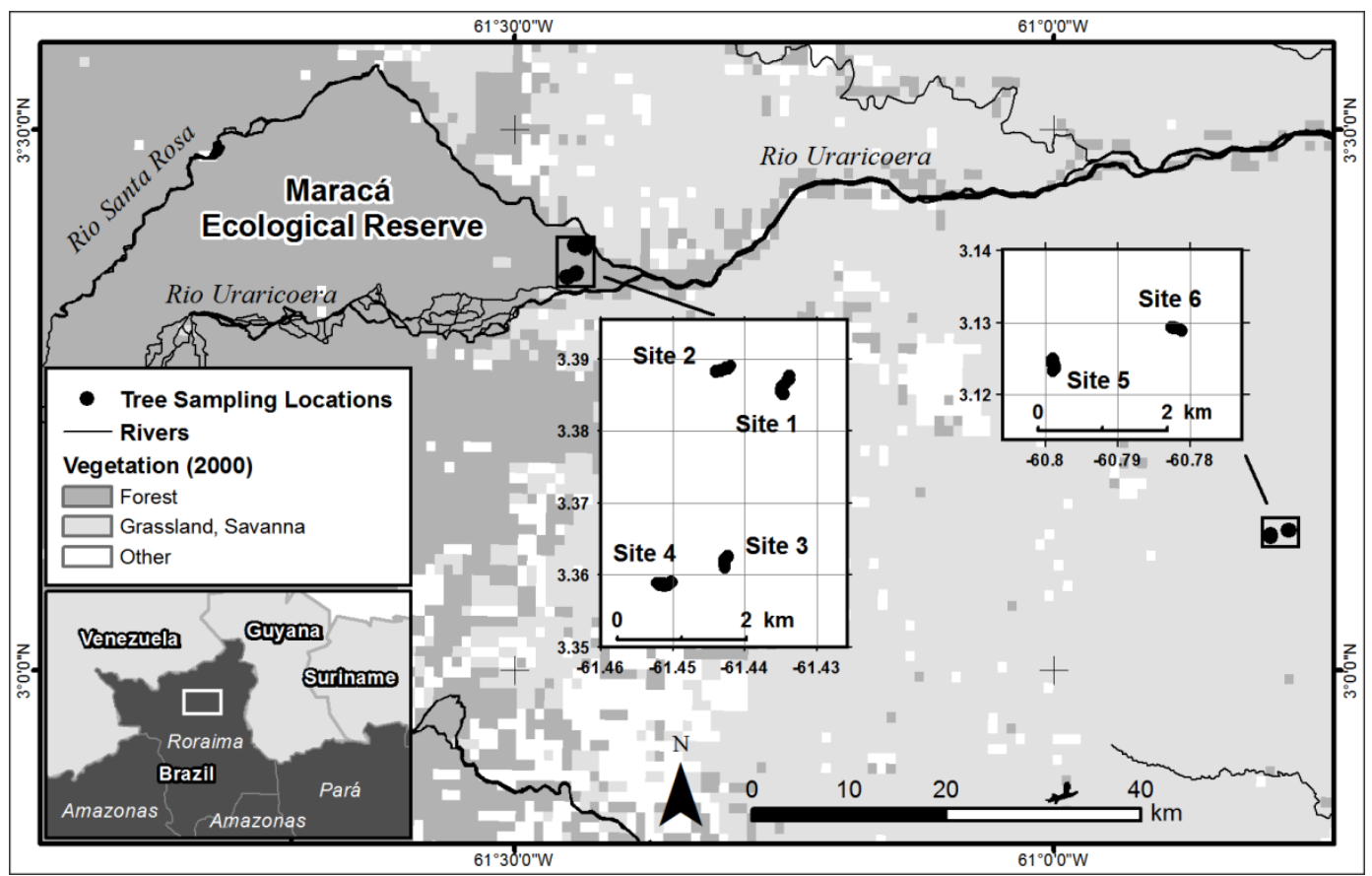


FIG. 2a. Mean number of seeds per fruit produced by Mauritia flexuosa in each habitat in Roraima, Brazil; where UE is undisturbed ecotone, UF is undisturbed forest, and DS is undisturbed savanna; and where different letters indicate significant differences within years (Year 1: $P<0.001$, Year 2: $P<0.05$ ). Sample sizes: Year 1: UE $=276, \mathrm{UF}=281$, $\mathrm{DS}=275 ;$ Year 2: $\mathrm{UE}=282, \mathrm{UF}=326)$

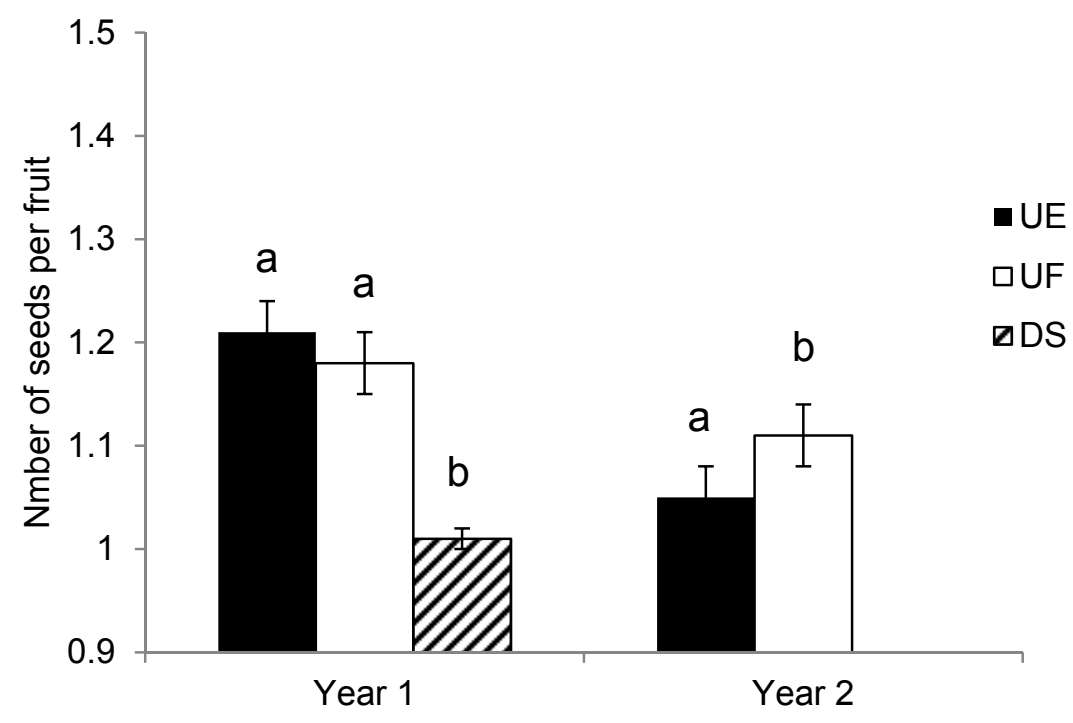


FIG. 2b. Mean seed dry mass (g) per fruit produced by Mauritia flexuosa in each habitat in Roraima, Brazil; where UE is undisturbed ecotone, UF is undisturbed forest, and DS is undisturbed savanna; and where different letters indicate significant differences within years $(P<0.001$. Sample sizes: Year 1: $\mathrm{UE}=277, \mathrm{UF}=281, \mathrm{DS}=277$; Year 2: $\mathrm{UE}=$ $282, \mathrm{UF}=326)$.

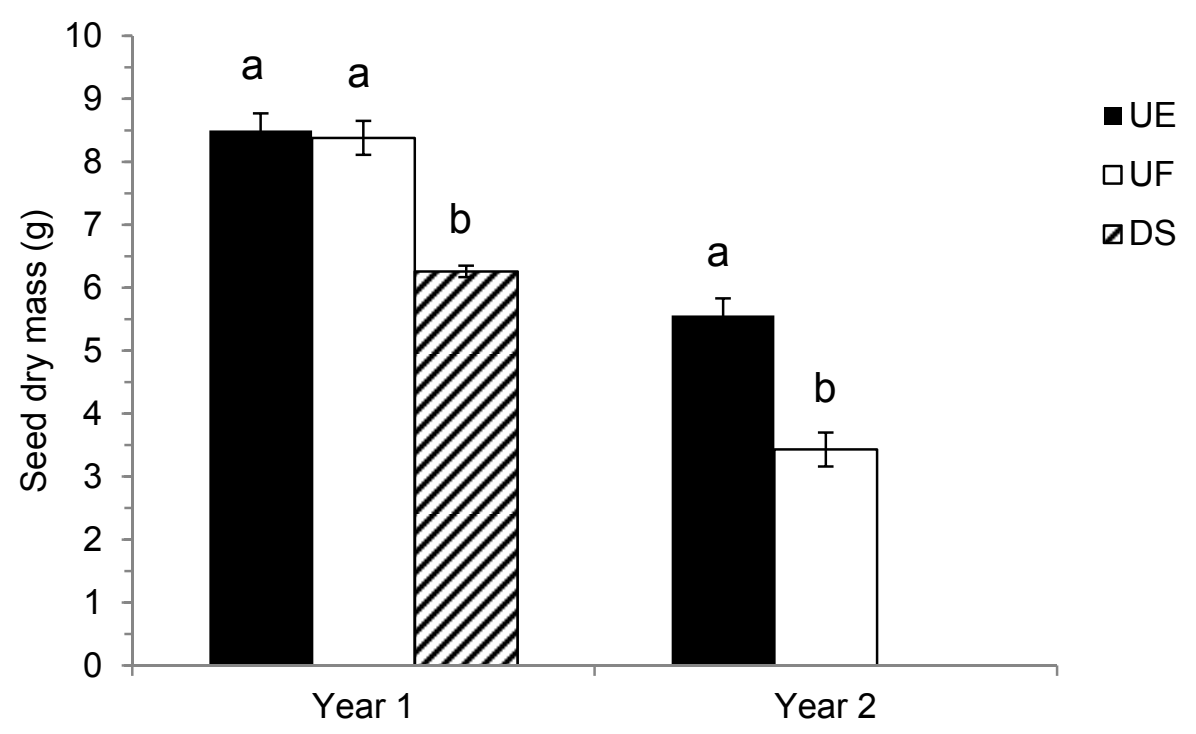


FIG. 2c. Mean fruit dry mass (g) produced by Mauritia flexuosa in each habitat in Roraima, Brazil; where UE is undisturbed ecotone, UF is undisturbed forest, and DS is undisturbed savanna; and where different letters indicate significant differences within years $(P<0.001)$. Sample sizes: Year 1: $\mathrm{UE}=278, \mathrm{UF}=296, \mathrm{DS}=296$; Year 2: $\mathrm{UE}=$ $266, \mathrm{UF}=325)$.

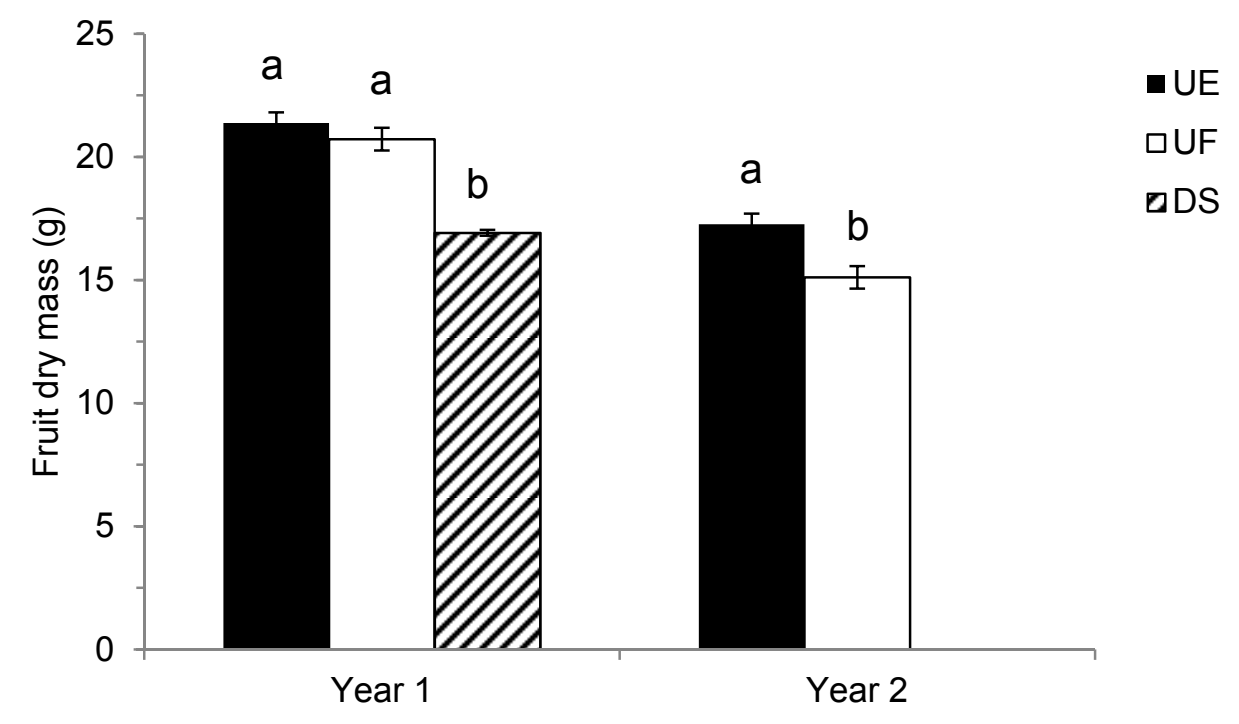


FIG. 2d. Mean fruit yield (kg) per Mauritia flexuosa female in each habitat in Roraima, Brazil; where UE is undisturbed ecotone, UF is undisturbed forest, and DS is undisturbed savanna; and where different letters indicate significant differences within years $(P<$ 0.05). Sample sizes: Year 1: $U E=12, U F=11, D S=12$; Year 2: $U E=11, \mathrm{UF}=13$ ).

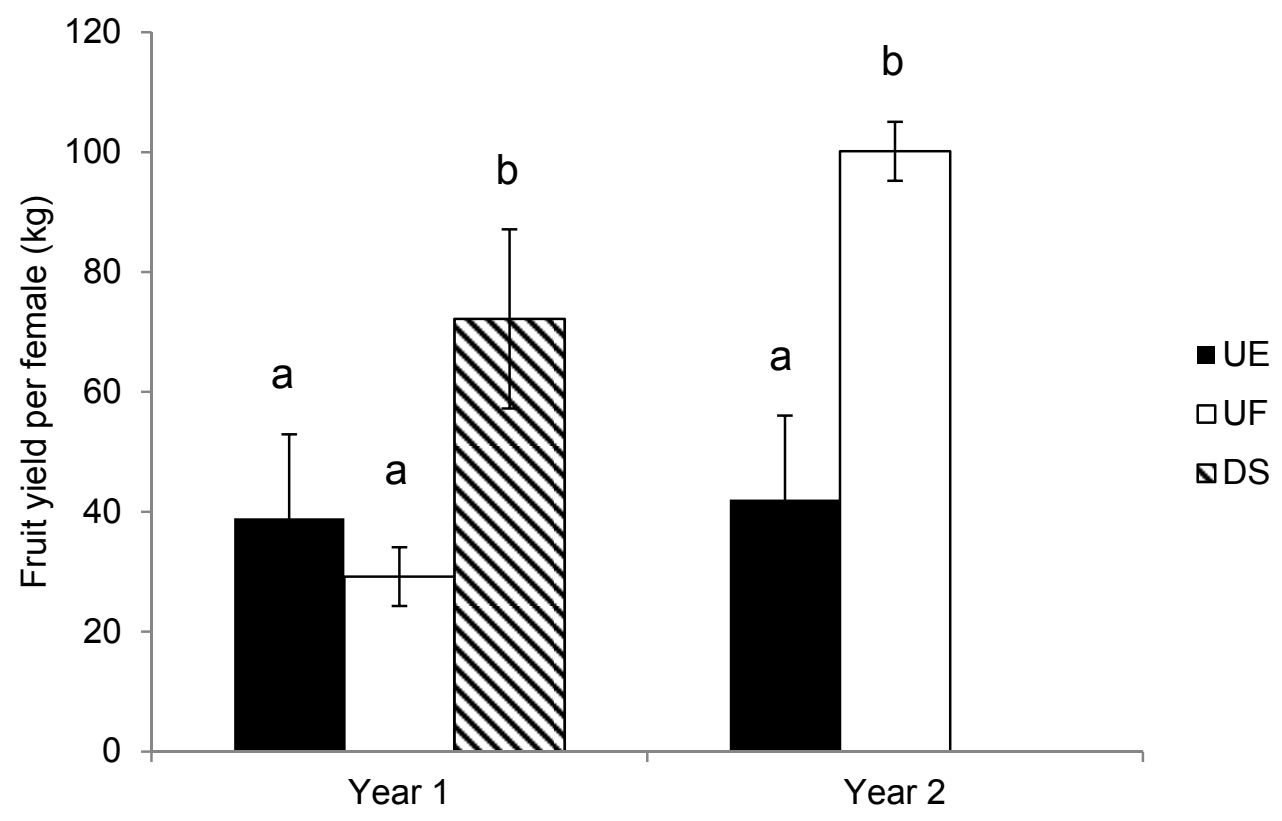


FIG. 3a. Mean height (m) of Mauritia flexuosa individuals in each habitat in Roraima, Brazil; where UE is undisturbed ecotone, UF is undisturbed forest, and DS is disturbed savanna; and where different letters indicate significance at $P=0.05\left(N_{\mathrm{UE}}=102, N_{\mathrm{UF}}=\right.$ $\left.144, N_{\mathrm{DS}}=128\right)$.

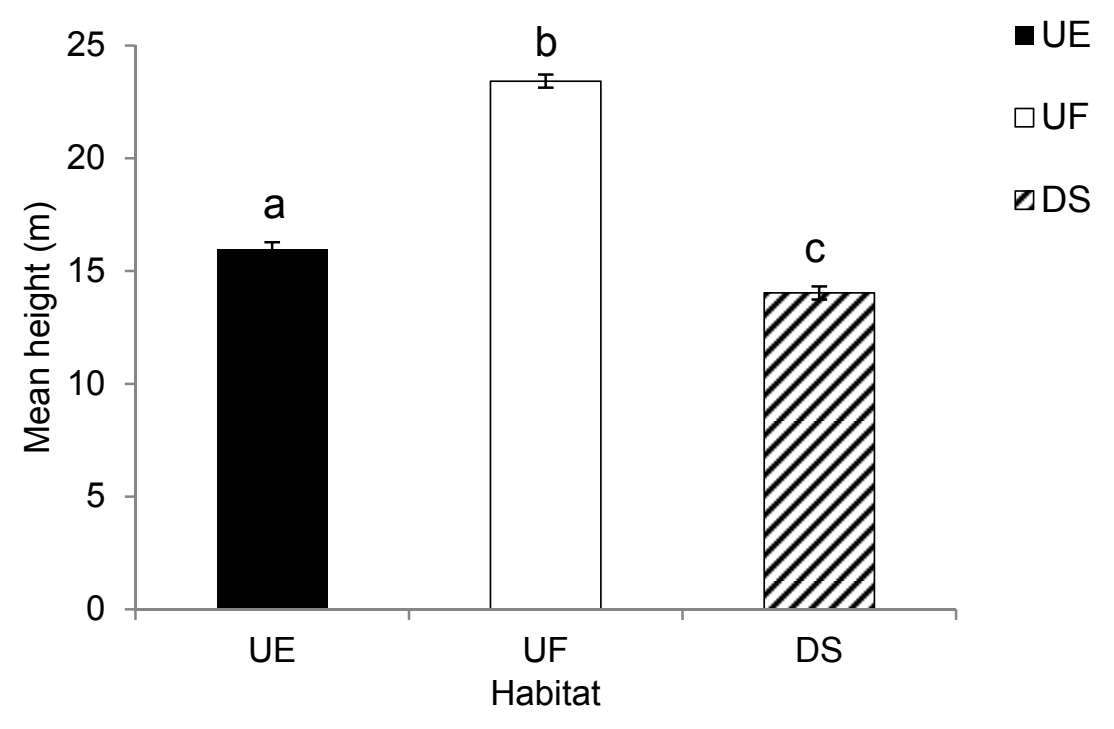


FIG. 3b. Mean diameter at breast height (m) of Mauritia flexuosa individuals in each habitat in Roraima, Brazil; where UE is undisturbed ecotone, UF is undisturbed forest, and DS is disturbed savanna; and where different letters indicate significance at $P=0.05$ $\left(N_{\mathrm{UE}}=102, N_{\mathrm{UF}}=144, N_{\mathrm{DS}}=128\right)$.

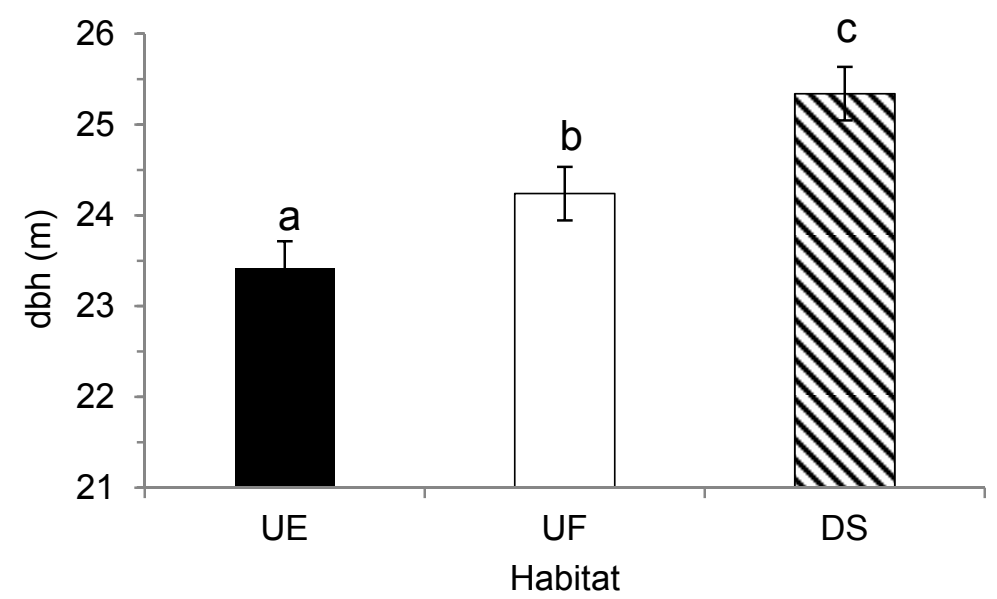


FIG. 3c. Mean crown volume $\left(\mathrm{m}^{3}\right)$ of Mauritia flexuosa individuals in each habitat in Roraima, Brazil; where UE is undisturbed ecotone, UF is undisturbed forest, and DS is disturbed savanna; and where different letters indicate significance at $P=0.05\left(N_{\mathrm{UE}}=\right.$ $\left.102, N_{\mathrm{UF}}=141, N_{\mathrm{DS}}=128\right)$.

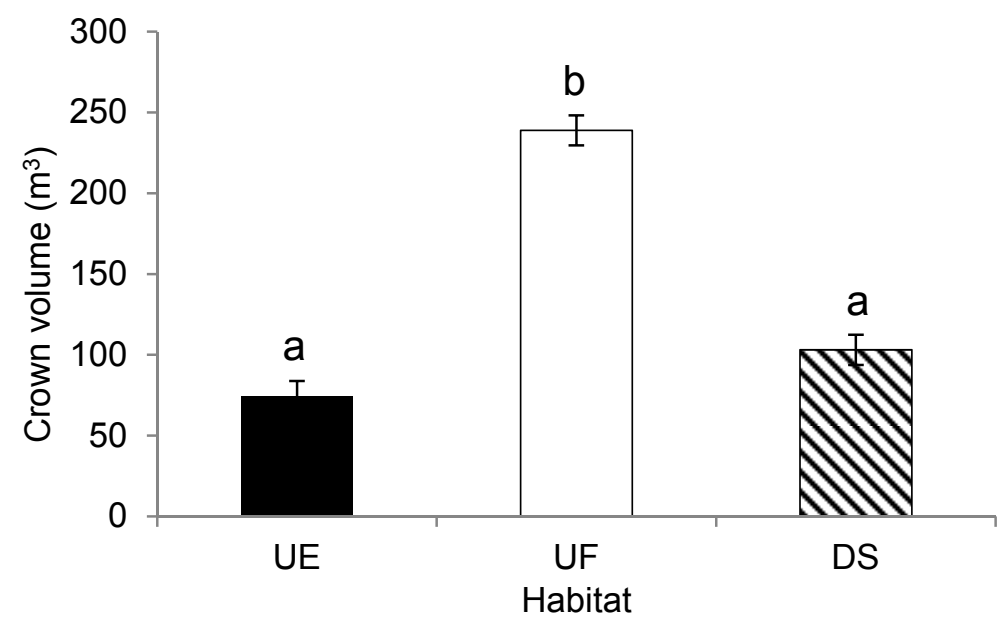




\section{CHAPTER IV}

MARKET DYNAMICS OF BURITI (MAURITIA FLEXUOSA) IN RORAIMA, BRAZIL: THE PATH TO COMMERCIALIZATION. 
Market Dynamics of Buriti (Mauritia Flexuosa) in Roraima, Brazil: the Path to Commercialization.

\section{ROXANEH KHORSAND ROSA ${ }^{1}$}

${ }^{1}$ Department of Biological Sciences, Florida International University, University Park, Miami, Florida, 33199, USA;

* Corresponding author: email: $\underline{\text { rkhor001@,fiu.edu }}$ 


\section{Market Dynamics of Buriti (Mauritia Flexuosa) in Roraima, Brazil: the Path to}

Commercialization. The non-timber forest product (NTFP), buriti (Mauritia flexuosa), plays a fundamental role in Amazonian economy, ecology, and culture. In contrast to western Amazonia, the market for this fruit remains poorly developed in regions of northern Amazonia. The objective of this study was to investigate the traditional knowledge of buriti, evaluate the regional market infrastructure and dynamics, and address the obstacles preventing the commercialization of this NTFP in Roraima, Brazil. Informal and semi-structured interviews were conducted with market vendors from the capital's four principal markets, and harvesters from two rural communities. Traditional knowledge of the reproductive ecology of M. flexuosa corroborated results from scientific studies, highlighting the validity of traditional knowledge and its potential to improve NTFP management. Vendors were unanimously unsatisfied with the current market state, arguing that the price of buriti must increase, and must fluctuate with varying supply. Other issues relating to the underdeveloped market include transportation, perishability, land tenure, destruction of natural habitat, management, and economic incentives. Harvesters echoed these issues in their critique of the current market state. If the public and private sectors provide economic incentives and invest in research, Roraima can expand its market infrastructure for buriti, effectively stimulating the regional economy, practicing sustainable harvesting, and involving local people in conservation. 


\section{Dinâmica do Mercado de Buriti (Mauritia Flexuosa L.f.) em Roraima, Brasil: O}

Caminho da Comercialização. Buriti (Mauritia flexuosa), um produto florestal nãomadeireiro (PFNM), possui um fundamental papel na economia, ecologia e cultura amazônica . Em contraste com o oeste da Amazônia, o mercado deste fruto permanece pobremente desenvolvido em regiões do norte amazônico. O objetivo deste estudo foi investigar o conhecimento tradicional do buriti, avaliar a infraestrutura e a dinâmica do mercado regional e, abordar os obstáculos que são impecílios à plena comercialização deste PFNM em Roraima, Brasil. Entrevistas informais e semi-estruturadas foram conduzidas com comerciantes das quatro principais feiras livres da capital, e com coletores de duas comunidades rurais. Conhecimento tradicional da ecologia reprodutiva de $M$. flexuosa corroborou os resultados de estudos científicos, destacando a validade do conhecimento tradicional e seu potencial para melhorar o manejo de PFNM. Comerciantes estavam unanimamente insatisfeitos com a atual situação do mercado, argumentando que o preço do buriti deveria aumentar e flutuar com a variação do abastecimento. Outras questões relacionadas ao mercado subdesenvolvido incluem transporte, perecibilidade, posse da terra, destruição do habitat natural, gestão e incentivos econômicos. Coletores ecoam estas questões em suas críticas sobre a atual situação do mercado. Se o setor público e privado providenciam apoio econômico e investimento em pesquisa, poderiam fazer com que Roraima expandisse sua infraestrutura de mercado para o buriti, efetivamente estimulando a economia regional, praticando a colheita sustentável, e envolvendo a população local na conservação. 


\section{Introduction}

Non-timber forest products (NTFPs), defined as any natural resource from the forest other than timber, have gained international attention since the late 1980s (Neumann and Hirsch 2000). The common argument has been that commercialization of NTFP's improves rural livelihoods and conservation by giving value to the standing forest, although recent studies challenge this perception (Belcher et al., 2005). Nevertheless, these products play an important role for subsistence in rural communities, and can be effective in reducing poverty and improving conservation if managed properly in parallel with market dynamics (Belcher and Schreckenberg 2007). Although many NTFPs have very low market value and thus little potential for generating income (Grimes et al. 1994) a few NTFPs have achieved substantial success in the marketplace and have potential to alleviate poverty.

A prime example of a profitable NTFP, notably in Brazil, is the palm fruit, açai (Euterpe oleracea). Açaí is now an international commodity; Brazil's annual production of açaí is estimated at 480000 tons (Brondízio 2008). Not surprisingly, management of this NTFP has become a profitable business in Brazil for both retailers and managers (Muñiz-Miret et al. 1996). Given the açaí industry's marketing of high levels of phenolic compounds and antioxidants, domestic and international demand continues to grow (Brokamp et al. 2011; Schauss et al. 2006; but see Seeram et al. 2008). The success story of açaí highlights the potential to commercialize and sustainably manage other palm products in Brazil.

The palm, Mauritia flexuosa, produces a promising NTFP for indigenous and nonindigenous communities of the Amazon. The fruits, referred to as buriti in Brazil, are 
consumed throughout the Amazon and in northeastern Brazil. Buriti boasts the highest beta-carotene (processed into vitamin A during metabolism) content of any food source, and higher levels of monounsaturated fatty acids than olive or Brazil nut oils, with cholesterol-reducing properties (Santos 2005; Silva et al. 2009). Therefore, following the açaí model, buriti should stand out as a profitable NTFP with major export potential. Despite this palm's broad economic and cultural importance, local markets for the fruit differ, with some regional markets being more developed than others. Although data exist on the market dynamics of M. flexuosa in western Amazonia (Brokamp et al. 2011), few studies have investigated the market dynamics in northern Amazonia. The objectives of this paper are to (1) document the local knowledge and harvesting practice of Mauritia flexuosa in Roraima, Brazil; (2) assess the current market dynamics and infrastructure; and (3) elucidate the obstacles that must be addressed to commercialize this NTFP.

\section{Methods}

\section{STUDY AREA}

I conducted my study in Roraima, in the northernmost part of Brazilian Amazonia (Fig. 1), a mosaic of phytoecological types and landscapes. The capital, Boa Vista, is situated in the southern part of the largest, continuous block of savannas in the Amazonian biome $\left( \pm 40000 \mathrm{~km}^{2}\right)$ (Barbosa and Fearnside 2005). The climate of this region is tropical wet-dry, 'Aw' (Köppen 1936). Annual precipitation ranges from 1100 to $1700 \mathrm{~mm}$ (Barbosa 1997). The peak dry season occurs from December through March, and the peak wet season from May through August.

Roraima is the most geographically remote state from the economic centers of Brazil, and was the last Brazilian territory to achieve statehood (1988). Historically, it was one of the 
least densely populated and most economically isolated regions until the mining boom of the 1980s, which caused its population to triple (Diniz 2008). Cattle ranching and government-related services also caused an influx of immigrants to the state (RosaFreitas et al. 2007).

\section{STUDY SPECIES}

Mauritia flexuosa L. f. (buriti) (Arecaceae, Calamoideae) is the most widespread palm in South America and one of the most massive, reaching heights of up to $40 \mathrm{~m}$ (Goulding and Smith 2007; Khorsand Rosa unpubl. data) (Fig. 2). The dioecious (separate male and female individuals) palm grows in savanna, forest, and savanna-forest ecotone habitats. It tolerates flooding, typically forming monodominant stands (buritizais) along streams, and in swamps. Mauritia flexuosa plays a central role in the ecosystem ecology in which it grows. Buritizais sequester significant amounts of carbon (San-José et al. 2010), and provide critical food and habitat for wildlife (Henry et al. 2000; Brightsmith 2005; Holm et al. 2008). Thus, effective management of this NTFP can directly benefit conservation of ecosystems.

Buriti fruits are globose to ellipsoid, scaly, measuring $4-6 \mathrm{~cm}$ in length and $3-5 \mathrm{~cm}$ in diameter, and usually one-seeded (Fig. 3a). Five morphotypes have been identified on the basis of color, size, and form of the exocarp (Barbosa et al. 2010). The bright yelloworange mesocarp, rich in beta-carotene, is used in cosmetics (Zanatta et al. 2008) and industrial products including biodiesel and plastics (Schlemmer et al. 2007; Andrade et al. 2012), and has significant, undeveloped potential as a pharmaceutical (Silva et al. 2009). Moreover, the fruits comprise an important part of the Amazonian diet (Delgado 
et al. 2007), and the leaves represent critical construction material for indigenous communities (Kahn, 1991).

\section{REPRODUCTIVE ECOLOGY OF MAURITIA FLEXUOSA}

The lack of scientific studies on the ecology of NTFP's pose a major obstacle to maximizing yields in a sustainable manner (Belcher and Schreckenberg 2007). Until recently, little was known about the ecology of $M$. flexuosa, specifically its reproductive biology. Khorsand Rosa et al. (see Chapter 1) analyzed the phenology and fruiting dynamics in the context of habitat heterogeneity and disturbance, Khorsand Rosa and Koptur (2013) investigated the pollination of M. flexuosa, and Khorsand Rosa et al. (Chapter 3) determined the key factors affecting fruit yield. In Roraima, a defined flowering period occurs between the wet and dry seasons (September through November), and is negatively associated with precipitation. Fruit maturation occurs during the wet season (May through August), correlating positively with precipitation. The entire process, from flowering through fruit maturation, lasts 8-12 months, depending on short-term climate variation and seasonality. Females can produce fruit during consecutive seasons, and pollen limitation is low. The species is wind-pollinated, independent of habitat. Habitat affects fruit and seed yield, although short-term climate variation may also play a significant role. Vegetative attributes, namely diameter at breast height, number of leaves, and height are good predictors of fruit yield. Crown volume cannot accurately predict yield.

\section{SAMPLING METHODS}

Price surveys of buriti and other fruits were conducted in each market, and market prices were converted from the Brazilian Real to US dollar. I conducted informal and semi- 
structured interviews with buriti vendors in the four largest markets (Feirão do Garimpeiro, Feira do Produtor Rural, Feira do Passarão, and Romeu Caldas de Magalhães) in Roraima's capital city, Boa Vista, from March through May, 2011. Group discussions were also carried out with harvesters representing two rural villages. A total of 28 interviews were performed, using a standardized questionnaire, which was approved (070908-00) by the Institutional Review Board at Florida International University. The questionnaire was translated to Portuguese, and all participants were informed of their right to not answer or terminate the interview before it was completed. Thirteen vendors were asked twenty questions including the relationship between price and seasonality, from whom and for how much they buy their fruits, the process of making buriti wine or vinho, knowledge of management, and what obstacles they face in the current market. Fifteen harvesters were asked twenty questions regarding harvesting for subsistence versus profit, the process of harvesting and transporting fruit to the market, where they harvest and why, access to land, if fruit availability has changed over their lifetime and the causes for these changes, and ecological knowledge of M. flexuosa. Data were organized into Excel spreadsheets. However, given the general consensus in responses, both among vendors and harvesters, no statistics were applied to these data. Although interview sample size may seem small, it represents a large portion of the universe of study. At all four major markets, I interviewed every vendor present and willing to speak to me. Given that $80 \%$ of Roraima's population is concentrated in the capital, Boa Vista (Diniz 2008), my results represent a large percentage of the state's vendors. The sample size further demonstrates the size of the current market in Roraima. 
The sample size of harvesters reflects the small number of harvesters surrounding Boa Vista, although there may be more in other areas of the state.

\section{Results}

\section{LOCAL KNOWLEDGE AND HARVESTING METHODS}

Both vendors and harvesters agreed that fruits are not available throughout the year; fruit collection begins during the wet season (May through August) and ends before the peak dry season. Thus, harvesting occurs only for about half of the year. Respondents were unable to give a specific answer when asked how long the process takes from flowering to fruit maturation. All estimated about one year. Respondents also unanimously agreed that females can produce fruits during consecutive years, although they did not know the age at which females begin to bear fruit. Several approximated ten years.

There are two common harvesting methods of buriti. The first and preferred method by harvesters is with a foice, or a curved blade attached to a long rod or branch. The second method involves climbing the palm with a peconha, a plant- fiber strap that is wrapped around the trunk and secures the harvester's feet, allowing him to shimmy up the trunk. Obviously, most harvesters use the first method as it is safer and energetically less demanding than climbing. However, the foice method only works for shorter individuals. Respondents that harvest for subsistence tend to use the peconha method. Subsistence harvesters also emphasized that they always leave some fruits on the palm, an apparent attempt at sustainable management.

Whether people harvest in the savanna or forest seems to be explained by where they live and/or sell their product, and the practicality associated with each habitat. Most vendors (92\%) could not guarantee from which habitat their product comes, as they do not 
harvest themselves. Only one vendor harvested his own fruit, and he harvested in the savanna. For harvesters living in Boa Vista and the surrounding area, accessing the savanna is more practical than the forest. Indigenous harvesters of Macuxi descent also told me that they harvest in the savanna, although they have access to forest on their land. In the savanna, $M$. flexuosa palms are the dominant growth form along waterways and the understory is less dense than in forests, where this species co-exists with other, shorter woody and herbaceous species (Khorsand Rosa pers. obs.). Thus, locating quality, fruiting females is easier in the savanna than in the forest. Height may also explain the preference for collecting in the savanna. Forest individuals are significantly taller than savanna or savanna-ecotone individuals (Khorsand Rosa and Koptur, 2013). Indigenous harvesters of Yanomami descent told me they harvest exclusively in the forest, as their land is predominantly forest.

Respondents agreed that fire negatively affects fruit crop of M. flexuosa. Their explanations included that fire dries the fruits, stunts growth, and kills seedlings. Because of the increased frequency of fire, respondents claimed that there are fewer fruits than there were thirty years ago. The decrease in fruit availability could also be a result of increased population growth and drought, such as the major drought of 1997. However, despite the perceived decline from an earlier period, respondents noted that fruits are still abundant, and easy to find. Leaves, however, are perceived to have less abundance, as a result of heavy harvesting for thatch by Macuxi communities (Hada 2010). Respondents expressed concern about the increasing difficulty of obtaining leaves for thatch, and the implications for their communities. 


\section{CONSUMPTION OF FRUITS}

Vendors and harvesters described several fruit morphotypes, and emphasized that certain types are superior in quality and flavor. Respondents emphasized that fruit size is not necessarily correlated with quantity of pulp. Contrary to expectation, small fruits produce more pulp than large fruits. Vendors also prefer small fruits because they tend to soften more quickly than large fruits, accelerating the harvest-to-final-product-process. Long, thin fruits are the least preferred because they yield the least amount of pulp. All vendors sell buriti wine (vinho) (Fig. 3b), not whole fruits. The thick vinho is typically eaten with sugar and toasted manioc flour (farinha), much like milk is eaten with granola. A general process of preparing fruits for vinho is accepted among vendors, although slight variations exist within the process. Fruits must be ripe when picked from the tree, and then are set to "breathe" for two to four days (Fig. 3c), depending on the degree of ripeness. Fruits are then soaked in water for a minimum of 24 hours and a maximum of three days. Some vendors specified hot water, while others said warm, and still others used cold. Once the fruits are soft from soaking, they are put into a machine to process the pulp. Water is added in small quantities. The scales are separated from the pulp, leaving behind the thick liquid, vinho. This thick liquid is filtered one last time to remove any pulp fibers or impurities (Fig. 3d). Harvesters, who do not have costly processing machines, but consume vinho as part of their daily diet, hand- scrape the scales off the softened fruits, and dilute the pulp with water.

\section{MARKET DYNAMICS IN RORAIMA}

The price of buriti vinho remains constant among Boa Vista's markets. Vendors sell one kilogram for US\$0.50/ kg. Although fruit supply is lowest during the peak dry season 
(December through March) and highest during the peak wet season (May through August), the price of vinho does not fluctuate.

There was a consensus among vendors that a demand for buriti exists in Roraima, but that selling buriti is not profitable. Vendors purchase buriti fruits from harvesters in 25$\mathrm{kg}$ bags. Each bag costs US\$12.50-15.00, amounting to $\$$ US $0.50-0.60 / \mathrm{kg}$. Once the costs of material, labor, and energy are accounted for, vendors are lucky to break even. Although vendors did not complain about the price they pay for fruits, they emphasized that the price of vinho must be increased and that this price increase must be formal and unanimous among all vendors. To my knowledge, no cooperative specifically for buriti, currently exists in Roraima to bring about such changes.

Only one vendor exclusively sold vinho, although this activity was not her primary form of income. All other vendors selling vinho as their major form of income also sold other fruit pulps to compensate for the depressed price of buriti (Fig. 3e, Fig. 3f). For example, local fruits such as passion fruit (Passiflora spp.), cupuaçu (Theobroma grandiflorum), and acerola (Malpigia glabra), are pressed into pulp and sold at a premium price of US\$1.5-2.5/kg. Açaí (Euterpe oleracea and E. precatoria) sells for five times the price of buriti, or \$US $2.5 / \mathrm{kg}$. Vendors continue to sell buriti despite its low price because it attracts and maintains clientele, making it a loss leader. Customers usually first buy buriti, and then buy other, more expensive, fruit pulps. If vendors do not have buriti, customers typically walk away to the next vendor, where they will buy both buriti and other pulps. 


\section{PERCEPTION OF MARKET BY VENDORS AND HARVESTERS}

Vendors and harvesters, alike, expressed general dissatisfaction with the market infrastructure. Harvesters complained that transportation to the city markets is expensive and impractical, especially during the wet season, when unpaved roads are impassable. A general consensus among vendors was that they need some type of economic incentive to develop their businesses and increase sales. One vendor at the Passarão Market expressed frustration with the city of Boa Vista, which plans to close down the market. The stagnant price of vinho and high variability in supply exacerbated vendors' dissatisfaction with the entire situation.

Another challenge for both harvesters and vendors seemed to be perishability. Fresh vinho must be refrigerated or kept on ice, which presents another expense for vendors. Fresh fruits must be brought to the market within a few days of harvesting to ensure freshness.

\section{ROLE OF WOMEN}

Women are important players in the buriti market. In Roraima, women typically do not harvest because the palms are so tall and collecting fruits is physically strenuous, traditionally associated with masculinity. However, women play a major role in the processing, transaction and management of fruits. The majority of vendors ( $70 \%$ male) commented that women are responsible for the functioning of the market, although they are not as visible as men. Not only do women process the fresh fruits into vinho, but they also manage the fruit-to-final product chain, and interact directly with customers. 


\section{Discussion}

\section{IMPORTANCE OF TRADITIONAL KNOWLEDGE IN NTFP MARKET}

Traditional ecological knowledge is defined as the cumulative body of knowledge about the interactions between living things (including people) and their environment, that is handed down across generations through cultural transmission (Berkes 1999). Traditional knowledge has significant potential to contribute to biodiversity conservation and sustainable use of NTFPs (Charnley et al. 2007; Donovan and Puri 2004). The harvesters with whom I spoke, of indigenous (Macuxi and Yanomami) descent, as well those of mixed indigenous and European descent (caboclos), gave valuable information regarding the reproductive ecology of Mauritia flexuosa. Their phenological knowledge including the timing and duration of flowering, period of fruit maturation, and ability of females to reproduce in consecutive seasons, corroborates the scientific data I collected during my two-year investigation of this palm's reproductive ecology. Local knowledge of when females begin to set fruit was ambiguous, however, suggesting that some information such as fruit initiation is considered less important than when actual harvesting occurs. Furthermore, respondents identified several fruit morphotypes, and distinguished between the quality and flavor of these morphotypes. Knowledge of repondents is supported by Barbosa et al. (2010), who identified five morphotypes on the basis of shape, size, and color of the fruit. The accurate knowledge and harvesting strategies local people have can be applied to management and cultivation initiatives of M. flexuosa, as has been done with other wild-harvested plants (Farooquee et al. 2004; Muok et al. 2000). Apparently, local people already have some knowledge about sustainable harvesting, as they leave some fruits on the palm for regeneration purposes. 


\section{EXPLORING THE MARKET}

Clearly, a demand for buriti exists in Roraima, but this demand is sluggish. The paradox between demand and stagnation, therefore, raises the question: why is selling buriti in Roraima unprofitable, and how can the market expand to make commerce of this NTFP profitable? Multiple factors must be addressed in the commercialization of NTFPs: market access, transportation and road conditions, perishability, land/ resource tenure, unpredictable product variability, international markets and export revenue, management, price and supply dynamics, value chains, and economic alternatives to harvesting (Belcher and Schreckenberg 2007; Kusters et al. 2006; te Velde et al. 2006;). MARKET ACCESS, TRANSPORTATION, AND PERISHABILITY OF BURITI Access to the market strongly affects harvesters' ability and willingness to sell their product. In the case of buriti in Roraima, harvesters often must travel far to reach the city. Roraima has only a few national highways, and most roads leading to wild areas, where large populations of Mauritia flexuosa occur, are unpaved. Because most harvesters do not have the capital to invest in their own vehicle, they must rely on the bus, which is unpredictable and impractical. Further, the peak harvesting season of buriti occurs during the wet season, when many roads are impassable, and consequently, public transportation to rural areas is even more precarious than during the dry season. Exacerbating the situation, fresh fruits are perishable, and must be sold soon after harvesting. Fruits are commonly transported in 25-kg plastic bags. Given the humid conditions, fruits can rot if stored in plastic for several days, adding another challenge for harvesters. Shanley et al. (2002) described the same situation for harvesters of local fruits in the Eastern Amazon, 
and added that challenges associated with complicated transportation during the wet season and perishability discourage many rural harvesters.

Perishability of the final product, vinho, also poses challenges for vendors in Roraima. Vinho lasts a maximum of three days in the refrigerator. Old vinho differs from freshly pressed vinho in that the oil layers separate, the color fades from bright yellow-orange to orange-beige, and the taste acidifies. Thus, vendors must process and sell their final product within 24 hours. Vinho must also be kept cold at the market, adding another challenge to vendors working in non-air conditioned, open markets.

\section{LAND TENURE}

Land tenure and socioeconomic level are closely related throughout the world, and highlight another challenge for rural harvesters (Phillips 1993). Access to the NTFP in question requires access to land which is often privately owned. Belcher and Schreckenberg (2007) highlighted the fact that harvesters typically harvest NTFPs in distant lands over which they have no secure tenure. This fact increases not only the possibility of unpredictable product variability, but also a lack of access to these areas. In northern and central Roraima, many M. flexuosa populations are located on privately owned ranches (fazendas) or federally recognized Indigenous Lands. Gaining access to these areas for landless, non-indigenous harvesters is extremely difficult, perhaps explaining, in part, why so few harvesters exist. Although vendors had heard of more harvesters, they interacted on a regular basis with a maximum of only three harvesters.

\section{ANTHROPOGENIC DISTURBANCE}

Another obstacle that harvesters face in Roraima is the increasing reality of fire, ranching, and logging in wild areas. Amazonian savannas and forests are rapidly being 
converted into agriculture and ranching and are exposed to recurring fire. A weighted average of $38 \%$ (27-85 \%) of total area of savanna is burned annually in Roraima (Barbosa and Fearnside 2005). Ranching and fire are positively associated, as ranchers seek out new pasture for their livestock (Arima et al. 2007). Not only does the frequency of fire complicate matters for harvesters, but ranchers fence off their properties. Consequently, harvesters must travel farther to find accessible land that is not burned. Shanley et al. (2002) also reported the important consequences that anthropogenic activities have on NTFP fruit harvesters in the eastern Amazon. Not only do ranching and logging deplete NTFP resources, but they also offer more lucrative economic alternatives to rural communities and decrease the perceived value of NTFPs.

\section{INTERNATIONAL MARKETS, MANAGEMENT AND CULTIVATION}

The size and nature of a market play a critical role in the commercialization process of NTFPs (Belcher and Schreckenberg 2007). Exporting outside the producing region tends to increase the price, expand the market, and stimulate local, economic growth (Haggblade et al. 2002). International demand for a NTFP increases its local value, incentivizing harvesters to sell their product rather than use for subsistence. In contrast to other Amazonian NTFPs such as palm hearts or açai, the export market of buriti is neglible (Brokamp et al. 2011). Roraima does not export buriti. However, vendors reported that if export possibilities were to exist, they would export their product. Clearly, an external demand for buriti exists; the city of Iquitos, Peru, consumes an estimated 150 tons of buriti (referred to as aguaje in Peru) per month. Harvesting is not carried out sustainably, however. Harvesters fell approximately 24000 females per year to meet demand (Delgado et al. 2007), and a recognized scarcity of aguaje in Peru has spurred 
initiatives for management (Manzi and Coomes 2009). No volume figures are available for buriti in Roraima, reflecting the stagnant demand. Felling of females is uncommon in Roraima, and supply is far from exhausted.

One solution to the strained Peruvian market is to cultivate M. flexuosa in agroforestry systems (Penn and Neise 2004). In contrast to agricultural products, NTFPs come from wild plants and are subject to greater variability both in quantity and quality. Management may significantly reduce this variability, ultimately increasing yields and profits (Kainer et al. 2006; Shanley et al. 2002). In Colombia, Castaño et al. (2007) estimate that yields of M. flexuosa fruit double in plantations as compared to wild populations. Despite the positive effect management can have on product yields, no management or cultivation of buriti currently exists in Roraima. In all four markets where interviews took place, vendors confirmed that their fruits were wild-harvested. No vendor had heard of any existing management or cultivation in the state. I met a local businessman who had no role in the current buriti market but had plans to cultivate $M$. flexuosa in south-central Roraima, to sell the fruits. He commented that his plan would be the state's first cultivation and official management of buriti. His plan did not materialize during my three years in Roraima.

Cultivation of a wild NTFP requires substantial capital investment to begin commercial production. A particular problem is that Mauritia flexuosa typically does not set fruit before eight to ten years of age, suggesting a long wait for any return on investment. Although management could effectively reduce this amount of time, one must have the capital to plant a large number of males and females to guarantee pollination, and expect no economic return for at least five years. Thus, managing and/or cultivating buriti 
requires greater capital than most actual harvesters have. Furthermore, cultivating a dioecious species is especially complicated because the sex of the plant is revealed only upon flowering, typically beginning after ten years. Despite these difficulties, cultivating M. flexuosa may be an inevitable response to depleting resources in high-demand regions such as Peru. Manzi and Coomes (2009) reported one such management initiative in northeastern Peru, although the ability of small projects to satisfy the enormous demand for M. flexuosa fruit in Peru is questionable.

Importing buriti from other Amazonian states with underdeveloped markets, such as Roraima, may also be a viable solution for Peru. In this scenario, an inter-regional Amazonian market infrastructure would allow the high-demand, low-supply western region to import from the low- demand, high- supply northern region. Cultivation in Roraima would allow the state to manage yields for export purposes, consequently increasing the local market price of buriti. Sustainable harvesting incorporating ecological knowledge, effective management, and cultivation would need to be a priority, to prevent overharvesting as has occurred in Peru. The development of such a market would require harvesters and vendors in Roraima to organize associations or cooperatives that are politically independent and democratically controlled by their members, and demand fair-trade prices. A prime example of this type of organization on the part of producers is the agroforestry crop, cacoa (Sutton 2012).

The public sector can provide some initial economic incentive to producers, and invest in ecological research for the NTFP, as the Finnish government has done with harvesting of wild berries (Laird et al. 2010). The private sector, however, can also contribute to the development of the buriti market. Management of NTFPs by private firms has been 
shown to be more efficient and flexible than if managed by public agencies (Tomich 1996). However, initial demand must be sufficient to attract private investors. Public agencies may be most effective at spurring initial demand. In the case of buriti in Roraima, the federally funded, Brazilian Enterprise for Agricultural and Husbandry Research (EMBRAPA) has the necessary infrastructure and funding for research, which could increase demand. Diverse types of agricultural research on M. flexuosa have been conducted by EMBRAPA in the Brazilian northeast (Baia et al. 2012), Cerrado region (Spera et al. 2001), and the Amazon (EMBRAPA 2004). The EMBRAPA branch in Roraima intended to begin a pilot project, using fruits from a M. flexuosa population growing naturally on the property to produce biodiesel, although this project has not yet been executed (Joaci de Freitas Luz-pers. comm.). International demand for buriti could potentially develop in the US, Europe, and Asia, as has occurred for açaí. Multi-national cosmetic companies including the Body Shop, Aveda, and L'Occitane produce beauty products that contain buriti oil. Although buriti is mainly consumed as a food source in South America, the international palate for this fruit and its derived products such as ice cream and jam could develop given appropriate marketing. The nutritional qualities of buriti need to be advertised, highlighting its "superfood" status (Lunn 2006), and increasing the potential for international demand. If production is conducted sustainably (both socially and ecologically), Roraima could play a major role in supplying the international market.

Cultivation of NTFPs has been proposed as an effective manner to mitigate harvesting pressures on wild plants (Trauernicht and Ticktin 2005). Cultivation of M. flexuosa could maximize fruit yields without jeopardizing ecosystem interactions and could also 
ameliorate the current crisis in leaf overharvesting. Overharvesting of leaves for thatch threatens the traditional architecture of the Macuxi in Roraima. Fruits, as well as leaves, could be sustainably harvested in cultivation, achieving two purposes: 1) allowing wild populations to regenerate; and 2) preserving the cultural practices of Roraima's main indigenous ethnicity.

\section{PRICE AND SUPPLY DYNAMICS}

It is also important to consider the relationship between supply, demand, and price of an NTFP and (Lawrence et al. 2005). The local price, supply, and perceived value of an NTFP are profoundly inter-dependent. In the case of wild-harvested fruits (piquiá, bacuri, and $u x i$ ) in the eastern Amazonian markets of Belém (Pará), supply determines the price of fruit, and consequently, consumers' willingness to pay premium prices (Shanley et al. 2002). During the dry season, availability of these fruits is very low, and prices increase. During the wet season, when harvests peak, prices drop. In the markets of Iquitos, Peru, the same pattern holds for M. flexuosa fruits (aguaje). The price of fruits varies up to five-fold between the peak harvesting season (US\$0.06-0.07/ $\mathrm{kg}$ ) and the low season (US\$1.50-1.70/kg) (Anonymous 2005). This relationship does not hold true for buriti in Roraima, however. Regardless of the high supply in the wet season and very low supply during the dry season, the price of buriti vinho remains fixed at US $\$ 0.50 / \mathrm{kg}$ (2011). Paradoxically, vendors buy fruits from harvesters at a constant price of US $\$ 0.50-0.60 / \mathrm{kg}$ throughout the entire year.

Furthermore, the price of buriti in Roraima has not increased over the past three years (2009-2011), despite increases in gasoline and other commodities. The price stagnation contrasts with other NTFPs in the eastern Amazon, which increased three to six times in 
the past six years (Shanley et al. 2002). Similarly, the price of aguaje in Iquitos, Peru, continues to increase as demand grows and supply shrinks (Brokamp et al. 2011). The unchanging, low market price of buriti makes earning a profit difficult for vendors. To overcome this difficulty, vendors sell their product at various markets in Boa Vista and rely on additional forms of income.

\section{VALUE CHAINS}

Although the market infrastructure for buriti in Roraima is small when compared with that of Iquitos, the value chain in Roraima is also reduced, allowing for whatever thin profit margin that may exist for harvesters and vendors. Measuring a market's value chain, or the number of actors involved in the production process, is essential to understanding entrepreneurship and innovation in the market of NTFPs (te Velde et al. 2006). In Iquitos, the value chain for aguaje is long, often involving primary harvesters, several levels of intermediaries, wholesalers, street vendors, and retailers (Brokamp et al. 2011). The long value chain increases the final price consumers pay, and minimizes earnings made by harvesters. Conversely, the value chain for buriti in Roraima consists of harvesters and street vendors; all vendors with whom I spoke bought directly from harvesters. Although frozen buriti pulp is available in supermarkets, the quantity sold to consumers is significantly less than at open markets, as locals strongly favor fresh vinho processed and sold by individual vendors (Khorsand Rosa, pers. obs.). Thus, developing the buriti market in Roraima seems economically promising for harvesters and vendors, as long as the value chain remains short and direct interaction between harvesters and vendors continues. State cooperatives or associations organized by the vendors and harvesters, themselves, could ensure this type of interaction. 


\section{WHY IS THE BURITI MARKET STAGNANT?}

Socio-economic class may explain the unchanging demand for buriti observed in Roraima. In Boa Vista, buriti is generally consumed by the lower class and indigenous populations. Although a few members of the middle-to-upper class purchase vinho in the open markets, the rich do not represent a significant proportion of consumers of buriti. For example, in the few up-scale coffee shops of Boa Vista, where the upper class eats breakfast and later-afternoon snack (lanche), buriti vinho is not sold, in contrast to other local fruit juices including cupuaçu, açerola, açaí, and pineapple. Thus, the perceived value of buriti in Roraima remains low because it is associated with the poor. Further, buriti is not consumed in urban centers like Rio de Janeiro, Brasília, and São Paulo, as opposed to açaí (Lichtenthäler et al. 2005). Boa Vista is still a relatively small capital, with a total population of 450497 (IBGE 2010), and is highly influenced by external culture. The lack of interest in buriti outside of the Amazon may reduce its appeal to the upper-class of Boa Vista. If marketed as a superfood and consumed in urban centers, perhaps the perceived value of buriti by the upper class in Boa Vista would increase. An increase in perceived value could increase the price consumers are willing to pay for the product, consequently rendering the market more fluid.

\section{WOMEN AND NTFPS}

Finally, the role of women in the buriti market cannot be overlooked. Women have been shown to play an important role in the market dynamics of NTFPs, both from the perspective of production and consumption. Collecting or harvesting is often the responsibility of women, as in the case of Pandanus guillaumetii in Madagascar, for weaving mats (Fedele et al. 2011). Swiss women buy local NTFPs significantly more 
often than men (Kilchling et al. 2009). Furthermore, women often value NTFPs more than men, and view these products as forms of subsistence and economic revenue (Lawrence et al. 2005; Tiani 2001).

Our results suggest that women play an important role in the buriti market of Roraima, corroborating other studies in the Amazon. In the eastern Amazon, women process local fruits (piquiá, bacuri and uxi) into pulp and dominate the retail markets (Shanley et al. 2002). Studies on aguaje in western Amazonia report similar results. Urban women in Iquitos, Peru, derive significant income from selling aguaje (Padoch 1988). Women in Iquitos play such an important role in the sale of aguaje, they are referred to as aguajeras (Carrera 1999). Thus, if managed and harvested sustainably, and sold at a competitive price, the commercialization of buriti can empower women and elevate their financial role in family structure. With increasing authority in the buriti market, women will also play an increasingly important role in management of natural resources.

\section{Conclusions}

In conclusion, buriti plays a fundamental role in the lives of rural communities and market vendors in Roraima. However, the local market infrastructure for this NTFP is underdeveloped and demand is stagnant. Vendors are generally unsatisfied with the current market state, and there is a general consensus among vendors that the market must be improved by addressing the following issues: transportation and road access, perishability, land tenure, destruction of natural habitat, export requirements, management and cultivation, economic incentives, and price and supply variability. These same issues accurately describe other NTFP markets, and must be considered if NTFPs are to fulfill the expected outcome of improving livelihoods and conservation. 
Buriti may play an especially important role in the lives of women, allowing them to advance in socio-economic position and contribute to natural resource management. Other NTFP markets such as cacoa, wild berries, palm hearts, and açai offer examples of market organization and infrastructure. The western Amazon, notably Peru, serves as evidence that demand for buriti continues to grow. Roraima can potentially embrace this opportunity for economic growth if the state government and federal agencies incentivize locals to organize and produce. 


\section{Acknowledgments}

The author thanks all individuals who were interviewed for and participated in this study. The National Science Foundation (Award No. 0906083), Fulbright Commission Brazil, and Florida International University (Dissertation Year Fellowship) provided funding. D.

Bray, M. Donnelly, S. Koptur, S. Oberbauer, and S. Zona greatly improved the manuscript; D. Gann created the map of the study area; and R.I. Barbosa helped translate the abstract and questionnaires, as well as provide logistical support during data collection. 


\section{Literature Cited}

Andrade, R. D. A., E. Pozzebom, E. A. Faria, F. Dantas Filho, P. A. Z Suarez, and A. G. S. Prado. 2012. Thermal behavior of diesel/biodiesel blends of biodiesel obtained from buriti oil. Acta Scientiarum 34:243-248.

Anonymous. 2005. Plan de manejo forestal de Mauritia flexuosa "aguaje" 2005-2009. Reserva Nacional Pacaya Samiria. Comité de Manejo de Palmeras (COMAPA) "Veinte de Enero". Elaborado con apoyo técnico de ProNaturaleza. Iquitos, Peru, 52.

Arima, E. Y., C. S. Simmons, R. T. Walker, and M. A. Cochrane. 2007. Fire in the Brazilian Amazon: a spatially explicit model for policy impact analysis. Journal of Regional Science 47:541-567.

Baia, A. D. B., C. A. Costa, M. B. Nascimento, B. C. N. Oliveira, F. C. Oliveira, and I. L. S. Silva. 2012. Uso do óleo essencial de buriti (Mauritia flexuosa L.) no controle da microbiota de sementes de soja. $45^{\circ}$ Congresso Brasileiro de Fitopatologia - Manaus, AM.

Barbosa, R. I. 1997. Distribuição das chuvas em Roraima. Pages 325-335 in Barbosa, R.I., E. Ferreira, and E. G. Castellon, eds., Homem, Ambiente e Ecologia em Roraima. Instituto Nacional de Pesquisas da Amazônia (INPA), Manaus.

Barbosa, R. I. and P. M. Fearnside. 2005. Fire frequency and area burned in the Roraima savannas of Brazilian Amazonia. Forest Ecology and Management 204:371-384.

Barbosa, R. I., A. D. Lima, and M. Mourão Jr. 2010. Biometria de frutos do buriti (Mauritia flexuosa L. f.- Arecaceae): Producão de polpa e óleo em uma área de savana em Roraima. Amazônia: Ciência e Desenvolvimento 5:71-85.

Belcher, B., M. Ruís-Pérez, and R. Achdiawan. 2005. Global patterns and trends in the use and management of commercial NTFPs: Implications for livelihoods and conservation. World Development 33:1435-1452.

Belcher, B. and K. Schreckenberg. 2007. Commercialisation of non-timber forest products: A reality check. Development Policy Review 25:355-377.

Berkes, F. 1999. Sacred Ecology: traditional ecological knowledge and resource management. Taylor and Francis, Philadelphia.

Brightsmith, D. J. 2005. Parrot nesting in southeastern Peru: seasonal patterns and keystone trees. Wilson Bulletin 117:296-305. 
Brokamp, G., N. Valderrama, M. Mittelbach, C. A. Grandez, A. S. Barfod, and M. Weigend. 2011. Trade in palm products in north-western South America. Botanical Review 77:571-606.

Brondízio, E. S. 2008. The Amazonian caboclo and the açaí palm: Forest farmers in the global market 16. New York Botanical Garden Pr Dept.

Carrera, L. 1999. Aguaje (Mauritia flexuosa) a promising crop of the Peruvian Amazon. International Society for Horticultural Science Acta Horticulturae 531. II ISHS Conference on Fruit Production in the Tropics and Subtropics. http:// www.actahort.org (28 January 2013).

Castaño, N., D. Cárdenas, and E. Otavo. 2007. Ecología, aprovechamiento y manejo sostenible de nueve especies de plantas del departamento del Amazonas, generadoras de productos maderables y no maderables. Instituto Amazónico de Investigaciones Científicas - SINCHI. Bogotá: Corporación para el Desarrollo Sostenible del sur de la Amazonia, CORPOAMAZONIA.

Charnley, S., P. A. Fischer, and E. T. Jones. 2007. Integrating traditional and local ecological knowledge into forest biodiversity conservation in the Pacific Northwest. Forest Ecology and Management 246:14-28.

Delgado, C., G. Couturier, and K. Mejia. 2007. Mauritia flexuosa (Arecaceae: Calamoideae), an Amazonian palm with cultivation purposes in Peru. Fruits 62:157-169.

Diniz, A. 2008. Fluxos migratórios e formaçao da rede urbana de Roraima. Geografia 33:269-287.

Donovan, D. G. and R. K. Puri. 2004. Learning from traditional knowledge of non-timber forest products: Penan Benalui and the autecology of Aquilaria in Indonesian Borneo. Ecology and Society 9:3-26.

EMBRAPA. 2004. Acre instala Centro de Referência em Bioenergia. http://www.embrapa.br/imprensa/noticias/2004/junho/bn.2004-1125.1165354905/?searchterm=buriti (25 January 2013).

Farooquee, N. A., B. S. Majila, and C. P. Kala. 2004. Indigenous knowledge systems and sustainable management of natural resources in a high altitude society in Kumaun Himalaya, India. Journal of Human Ecology 16:33-42.

Fedele, G., Z. L. Urech, M. Rehnus, and J. P. Sorg. 2011. Impact of women's harvest practices on Pandanus guillaumetii in Madagascar's lowland rainforests. Economic Botany 65:158-168. 
Goulding, M. and N. Smith. 2007. Palms, sentinels for amazon conservation. Amazon Conservation Association, Missouri Botanical Garden Press, St. Louis.

Grimes, A., S. Loomis, P. Jahnige, M. Burnham, K. Onthank, R. Alarcón, and R. Mendelsohn. 1994. Valuing the rain forest: The economic value of nontimber forest products in Ecuador. Ambio 23:405-410.

Hada, A. R. 2010. O Buriti (Mauritia flexuosa L.F.) na Terra Indígena Araçá, Roraima: Usos tradicionais, manejo, e potencial produtivo. Master's Thesis, INPA, Manaus.

Haggblade, S., P. Hazell, and T. Reardon. 2002. Strategies for stimulating poverty: Alleviating growth in the rural non-farm economy in developing countries. EPTD Discussion 92. Environment and Production Technology Division, IFPRI, and Rural Development Department, World Bank, Washington, DC.

Henry, O., F. Feer, and D. Sabatier. 2000. Diet of the Lowland Tapir (Tapirus terrestris L.) in French Guiana. Biotropica 32:364-368.

Holm, J. A., C. J. Miller, and W. P. Cropper. 2008. Population dynamics of the dioecious Amazonian palm Mauritia flexuosa: Simulation analysis of sustainable harvesting. Biotropica 40:550-558.

IBGE, Instituto Brasileira de Geografía e Estatística. 2010. http://www.ibge.gov.br, (31 January 2013).

Kahn, F. 1991. Palms as key swamp forest resources in Amazonia. Forest Ecology and Management 38:133-142.

Kainer, K. A., L. H. O. Wadt, D. A. P. Gomes-Silva, and M. Capanu. 2006. Liana loads and their association with Bertholletia excelsa fruit and nut production, diameter growth and crown attributes. Journal of Tropical Ecology 22:147-154.

Khorsand Rosa, R. and S. Koptur. 2013. New findings on the pollination biology of Mauritia flexuosa (Arecaceae) in Roraima, Brazil: linking dioecy, wind, and habitat. American Journal of Botany 100:613-621.

Kilchling, P., R. Hansmann, and K. Seeland. 2009. Demand for non-timber forest products: Surveys of urban consumers and sellers in Switzerland. Forest Policy and Economics 11:294-300.

Köppen, W. 1936. Das geographisca system der climate. Pages 1-44 in Köppen, W. and G. Geiger, eds. Handbuch der klimatologie. Gebrüder Borntraeger, Berlin.

Kusters, K., R. Achdiawan, B. Belcher, and M. Ruíz- Pérez. 2006. Balancing development and conservation? An assessment of livelihood and environmental 
outcomes of nontimber forest product trade in Asia, Africa, and Latin America. Ecology and Society 11:20-42.

Laird, S. A., R. J. McLain, and R. P. Wynberg. 2010. The state of NTFP policy and law. Pages 341-365 in Laird, S. A., R. P. Wynberg, R. J. McLain, eds. Wild product governance: finding policies that work for non-timber forest products. Earthscan, London.

Lawrence, A., O. L. Phillips, R. A. Ismodes, M. Lopez, S. Rose, D. Wood, and A. J. Farfan. 2005. Local values for harvested forest plants in Madre de Dios, Peru: Towards a more contextualized interpretation of quantitative ethnobotanical data. Biodiversity and Conservation 14:45-79.

Lichtenthäler, R., R. Belandrino Rodrigues, J. G. S. Maia, M. Papagiannopoulos, H. Fabricius, and F. Marx. 2005. Total oxidant scavenging capacities of Euterpe oleracea Mart. (Açaí) fruits. International Journal of Food Sciences and Nutrition 56:53-64.

Lunn, J. 2006. Facts behind the headlines, superfoods. Nutrition Bulletin 31:171-172.

Manzi, M. and O. T. Coomes. 2009. Managing Amazonian palms for community use: A case of aguaje palm (Mauritia flexuosa) in Peru. Forest Ecology and Management 257:510-517.

Muñiz-Miret, N., R. Vamos, M. Hiraoka, F. Montagnini, and R. O. Mendelson. 1996. The economic value of managing the açaí palm (Euterpe oleracea Mart.) in the floodplains of the Amazon estuary, Pará, Brazil. Forest Ecology and Management 87:163-173.

Muok, B. O., B. Owuor, I. Dawson, and J. Were. 2000. The potential of indigenous fruit trees: results of a survey in Kitui District, Kenya. Agroforestry Today 12:13-16.

Neumann, R. P. and E. Hirsch. 2000. Commercialisation of non-timber forest products: review and analysis of research. Center for International Forestry Research, Bogor.

Padoch, C. 1988. Aguaje (Mauritia flexuosa L.f.) in the economy of Iquitos, Peru. Advances in Economic Botany 6:214-224.

Penn, J. W. and G. Neise. 2004. Aguaje palm agroforesty in the Peruvian Amazon. The Palmeteer 24:85-101.

Phillips, O. 1993. The potential for harvesting fruits in tropical rainforests: New data from Amazonian Peru. Biodiversity and Conservation 2:18-38. 
Rosa-Freitas, M. G., P. Tsouris, A. Townsend Peterson, N. Alves Honório, F. S. M. de Barros, D. B. de Aguiar, H. da Costa Gurgel, M. E. de Arruda, S. D. Vasconcelos, andJ. F. Luitgards-Moura. 2007. An ecoregional classification for the state of Roraima, Brazil. The importance of landscape in malaria biology. Memórias do Instituto Oswaldo Cruz, Rio de Janeiro 102:349-357.

San-José, J., R. Montes, M. Angel Mazorra, E. Aguirre Ruiz, and N. Matute. 2010. Patterns and carbon accumulation in the inland water-land palm ecotone (morichal) across the Orinoco lowlands, South America. Plant Ecology 206:361374.

Santos, L. M. P. 2005. Nutritional and ecological aspects of buriti or aguaje (Mauritia flexuosa Linnaeus filius): A carotene-rich palm fruit from Latin America. Ecology and Food Nutrition 44:345-358.

Schauss, A. G., X. Wu, R. L. Prior, B. Ou, D. Patel, D. Huang, and J. P. Kababick. 2006. Phytochemical and nutrient composition of the freeze-dried Amazonian palm berry, Euterpe oleracea Mart. (Açai). Journal of Agricultural and Food Chemistry 54:8598-8603.

Schlemmer, D., E. R. de Oliveira, and M. K. Araújo Sales. 2007. Polystyrene/ thermoplastic starch blends with different plasticizers. Journal of Thermal Analysis and Calorimetry 87:635-638 .

Seeram, N. P., M. Aviram, Y. Zhang, S. M. Henning, L. Feng, M. Dreher, and D. Heber. 2008. Comparison of antioxidant potency of commonly consumed polyphenolrich beverages in the United States. Journal of Agricultural and Food Chemistry $56: 1415-1422$.

Shanley, P., L. Luz, and I. R. Swingland. 2002. The faint promise of a distant market: A survey of Belém's trade in non-timber forest products. Biodiversity and Conservation 11:615-636.

Silva, S. M., K. A. Sampaio, T. Taham, S. A. Rocco, R. Ceriani, and A. J. A. Meirelles. 2009. Characterization of oil extracted from buriti fruit (Mauritia flexuosa) grown in the Brazilian Amazon region. Journal of American Oil Chemist Society 86:611-616.

Spera, M. R. N, R. Cunha, and J. B. Teixeira. 2001. Quebra de dormência, viabilidade e conservação de sementes de buriti (Mauritia flexuosa). Pesquisa Agropecuária Brasileira 12:1567-1572.

Sutton, S. 2012. Beyond price-fairtrade and capacity building. The case of Cooperativa Naranjillo in Peru. Pages 268-277 in Granville, B. and J. Dine, eds. The processes 
and practices of fair trade: trust, ethics and governance. Routledge Publishers, New York.

te Velde, D. W., J. Rushton, K. Schreckenberg, E. Marshall, F. Edouard, A. Newton, and E. Arancibia. 2006. Entrepreneurship in value chains of non-timber forest products. Forest Policy and Economics 8:725-741.

Tiani, A. M. 2001. The place of rural women in the management of forest resources: The case of Mbalmayo and neighboring areas in Cameroon. Pages 72-89 in Pierce Colfer, C. J., and Y. Byron, eds. People managing forests: the links between human well-being and sustainability. RFF Press, Washington D.C.

Tomich, T. P. 1996. Markets, policies, and institutions in NTFP trade: Nothing is perfect. International conference on domestication and commercialization of non-timber forest products in agroforestry systems. Nairobi. http://www.worldagroforestrycentre.org, (08 February 2013).

Trauernicht, C. and T. Ticktin. 2005. The effects of non-timber forest product cultivation on the plant community structure and composition of a humid tropical forest in southern Mexico. Forest Ecology and Management 219:269-278.

Zanatta, C. F., V. Ugartondo, M. Mitjans, P. A. Rocha-Filho, and M. P. Vinardell. 2008. Low cytotoxicity of creams and lotions formulated with Buriti oil (Mauritia flexuosa) assessed by the neutral red release test. Food and Chemical Toxicology 46:2776-2781. 
Fig. 1. Map of study area.

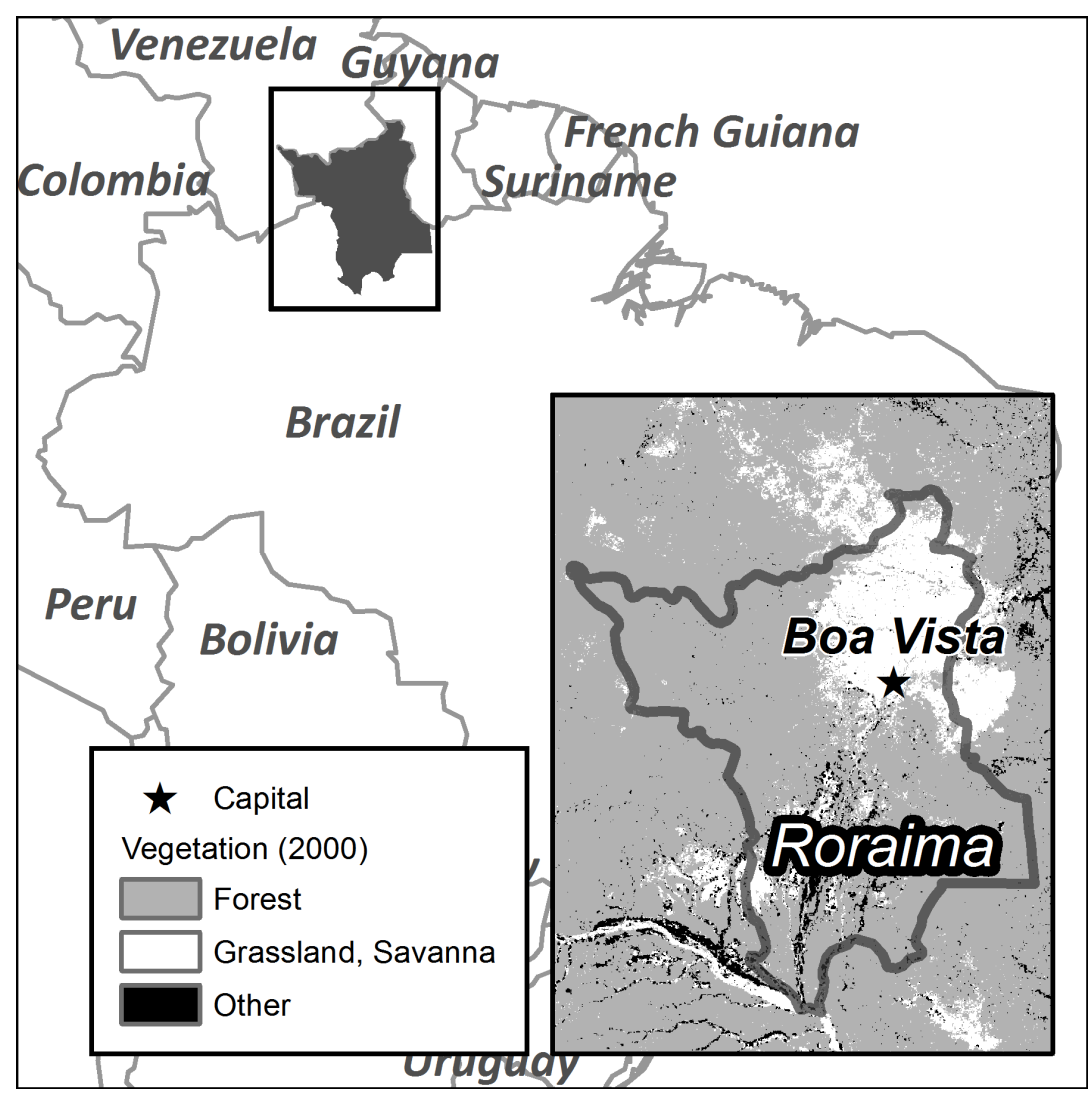


Fig. 2. Mauritia flexuosa population in savanna of Roraima, Brazil. Note male with inflorescence in foreground.

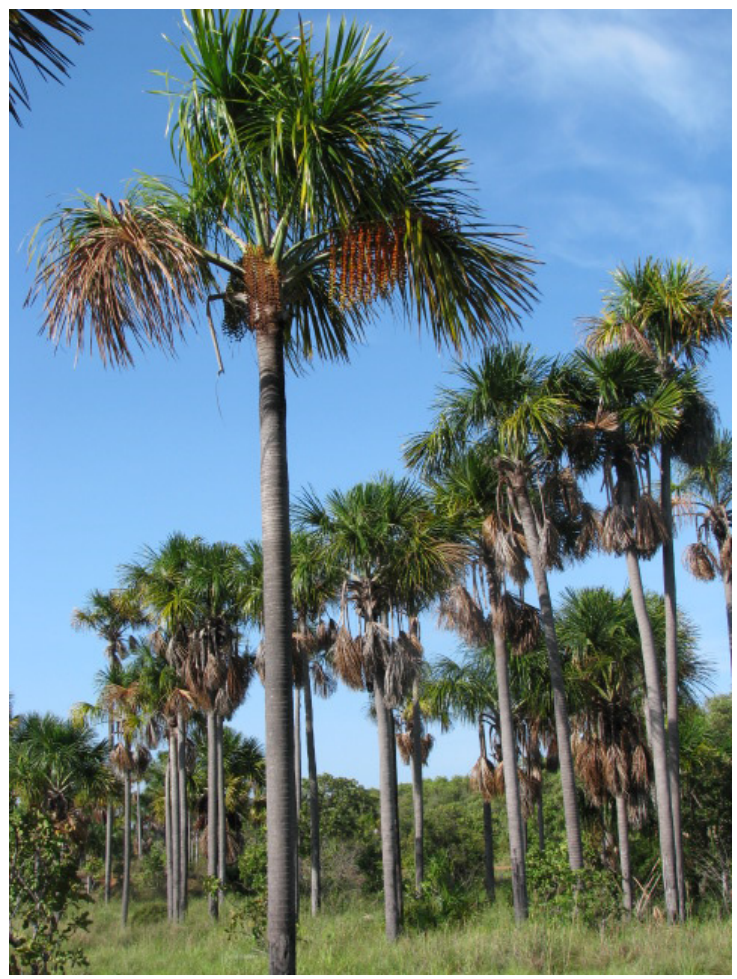


Fig. 3. Sale of buriti fruits in Roraima, Brazil. A. Fruits; B. Vinho for sale C. Buriti fruits ready for processing; D. Filtering vinho before packaging; E. Vendor in Feira do Produtor; note variety of pulps including buriti and açaí; F. Vendors in Feira do Garimpeiro selling buriti vinho and açaí (in bags).

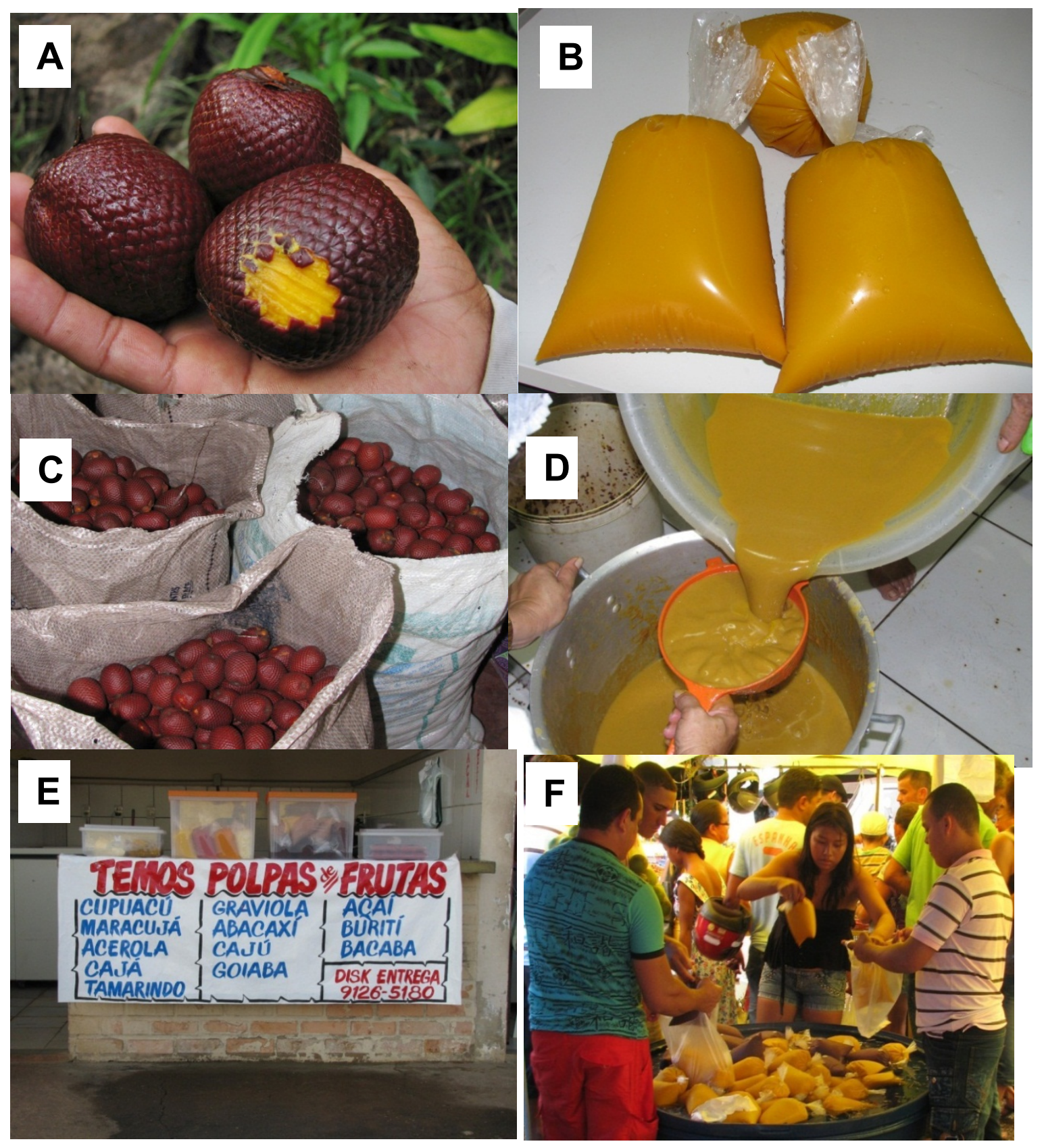




\section{CONCLUSIONS AND FUTURE DIRECTIONS}


The effect of the environment on species is a central theme in ecology (Guisan et al., 2000). Local variation of habitat and habitat disturbance can alter abiotic conditions, which in turn, influence species abundance and distribution, species interactions, regeneration patterns, and community structure (Castro et al., 2004; Kareiva, 1987; Hill and Hamer, 1998; King et al., 1998; Fagan et al., 1999; Valencia et al., 2004). One way in which plants adapt to their dynamic physical environment is through changes in allocation to reproductive growth (Bazzaz et al., 1987). Plasticity in reproductive processes, including shifts in phenology and alteration of reproductive output can be a response to temporal and spatial variation in the environment (Hedhly, 2009; Van Asch et al., 2007; Wookey et al., 1993). Habitat disturbance alters both the abiotic and biotic environment, affecting interactions between organisms critical to ecosystem function (Parminter, 1998). The introduction of exotic species is one form of habitat disturbance that can have profound consequences for the native ecosystem and species. Exotic plant species often overexploit resources, consequently altering critical reproductive processes such as pollination success of native species (Brown et al., 2002; Traveset and Richardson, 2006). The underlying theme of my dissertation addressed the influence of habitat variation and disturbance on the reproductive ecology of Mauritia flexuosa in Roraima, Brazil.

The major finding of my research is that habitat and disturbance affected some aspects of the reproductive ecology of M. flexuosa, while having no significant effect on other aspects. Chapter I demonstrated that flowering and fruiting phenology were similar between forest and ecotone habitats, as well as among undisturbed and disturbed habitats. All six populations flowered during the wet/dry season interface (August through 
November), and availability of mature fruit was highest during the peak wet season (May through July). The negative relationship between precipitation and flowering, and the positive relationship between precipitation and fruiting, were observed in all populations. These results highlight the importance that inter-annual climatic variation (including El Niño Southern Oscillation, ENSO), and not habitat, may play in phenology. Other studies have also found a close relationship between changes in phenology and climatic variation, particularly during ENSO years (Post et al., 1999; Stenseth et al., 1992; Walker et al., 1995).

In Chapter I, I also found no significant relationship between sex and habitat, suggesting that female-biased sex ratios were a result of resource patchiness or sampling variability. Long-term studies are necessary to determine the influence of seasonal variation, perhaps exacerbated by climate change, on the phenology of M. flexuosa. Ideally, a future study will examine phenological patterns in various regions of the Amazon to differentiate regional climatic variation effects from widespread, general trends in climate change.

Another novel finding of my research is that $M$. flexuosa is anemophilous in forest, ecotone, and disturbed savanna habitats (Chapter II). Previous studies (Ervik, 1993; Storti, 1993) had concluded beetles to be the principal pollinator of M. flexuosa, but did not distinguish between visitors and pollinators. My results are inconsistent with previous studies conducted on this species, and underline the importance of combining pollen-limitation experiments with field observations and laboratory analyses of floral visitors. The floral morphology of $M$. flexuosa, including fragrance and the presence of staminodes/pistillodes, suggests a carry-over from a hermaphroditic, entomophilous 
ancestor. To explain the dichotomy between floral morphology and pollination system in M. flexuosa, a future study would need to examine the floral biology and pollination of its closest relatives including Lepidocaryum, Mauritiella, and the other species of Mauritia, M. carana. Chapter II also showed that no significant relationship existed between habitat and pollen transfer, suggesting that transfer of pollen by wind is not necessarily more effective in closed habitats than open habitats, as has been previously assumed (Culley et al., 2002; Stebbins, 1970). Overall, these findings raise some important questions about the evolution of wind-pollination in angiosperms and challenge the assumption that windpollination is a reproductive strategy most commonly associated with temperate species.

Although abundance of native floral visitors was lower in the disturbed savanna than in the undisturbed habitats, pollination success of M. flexuosa was not affected because floral visitors (native or non-native) are not pollinators (Chapter II). It would be premature to conclude, however, that the presence of the exotic tree, Acacia mangium and non-native Africanized bees in the disturbed savanna do not present indirect threats to the reproduction of other native plants. Although anemophilous M. flexuosa may not be directly affected by changes in floral visitor composition and nectar source plants, other entomophilous species may be vulnerable to changes in the native pollinator diversity. Evidence strongly suggests that reduced diversity of native pollinators results in reduced fruit set of entomophilous plants (Klein et al., 2003; Rathcke and Jules, 1993; Steffan-Dewenter and Tscharntke, 1999).

In contrast to phenology and pollination, habitat did affect reproductive output of M. flexuosa (Chapter III). Fruit mass, seed mass, and number of seeds per fruit were significantly reduced in the disturbed habitat, consistent with other studies examining 
reproductive success in fragmented populations (Fuchs et al., 2003; Jennersten, 1988). Fruit yield was highest, however, in the disturbed habitat, suggesting that pollen limitation is not the determinant of fruit production in this species. In Chapter II, I showed that pollen limitation was very low. Rather, abiotic factors may explain the anomaly of increased reproductive output in a disturbed habitat. Soil moisture was the most important determinant of reproductive output, pointing to the critical role climatic variation may play in the reproductive ecology of M. flexuosa, and perhaps other species.

Spatial variation in resources within a habitat fluctuates less than temporal resource variation, brought on by inter-annual climatic variation. Thus, tropical plants may have evolved to adapt to relatively stable conditions characteristic of the local habitat, but respond to labile conditions caused by moisture fluxes. For example, the soils characterizing M. flexuosa in Roraima are aluminum-toxic and acidic. On the basis of my two-year study, in which aluminum toxicity and $\mathrm{pH}$ remained constant, it is likely that these soil qualities remain relatively constant from year to year. Mauritia flexuosa has likely adapted to this type of soil over its evolutionary course as a means of fitness. Fluctuations in rainfall, however, vary from year to year, and influence resource availability. From a fitness standpoint, it is logical to assume that a plant will alter its vegetative and reproductive growth according to changes in resource availability, although the response may not be manifested immediately (i.e. there are likely to be time lags). A future, long-term study could investigate the relationship between rainfall and seed mass in M. flexuosa as a proxy of plant response to short-term climatic variation.

Lastly, my dissertation described the underdeveloped buriti market in Roraima, outlined possible reasons for underdevelopment, and discussed factors that must be 
addressed to commercialize buriti successfully (Chapter IV). To my knowledge, no study has closely looked at the market dynamics of buriti, or any NTFP for that matter, in Roraima. Other studies have shown the important role that economic incentives and financial investment by both the public and private sectors play in commercialization of NTFPs (Belcher et al., 2005; Wollenberg, 2001). My results suggest that involvement by the public and private sectors is also necessary in Roraima to improve the profitability and perceived value of buriti. A future pilot project should organize a cooperative of buriti vendors and harvesters, which will have the authority to increase the price of buriti in response to supply. Simultaneously, local conservation groups can develop a partnership with an investor (not necessarily foreign) to begin management and cultivation of buriti, with the long-term objectives of sustainable harvesting, maintenance of native diversity, and stimulation of the local economy. Although this project may seem unrealistically ambitious, examples of similar projects include the cultivation of açaí (Euterpe oleracea) in Amapá, northern Amazonia, medicinal plants in Nepal (Edwards, 1996), and camu-camu (Myrciaria dubia) in Peru (Penn Jr., 2006).

Amazonian ecosystems are under increasing threats from climate change, exotic species, and habitat destruction (Laurance and Williamson, 2001; Lovejoy et al., 1986; Malhi et al., 2008; Parrotta and Knowles, 1999). To conserve Amazonian biodiversity effectively and predict how organisms will respond to anthropogenic change, we understand the multitude of interactions among abiotic and biotic players. One critical piece of the puzzle is the reproductive patterns of keystone or foundation species (Ellison et al., 2005), as recruitment patterns of these species have underlying consequences for interacting species and community processes (Smith and Knapp, 2003). My dissertation 
represents a small step forward in our understanding of Amazonian plant reproductive ecology and has practical implications for conservation and NTFP management. Specifically, as climatic variation in the tropics intensifies, plant species ranges will shift (Colwell et al., 2008). Thus, species composition will change, particularly in ecotonal areas. My data on the relationship between phenology, habitat variation, and rainfall provide insight into how the reproduction and distribution of M. flexuosa may shift in response to climatic variation. In addition, my research shows the abiotic factors responsible for fruit and seed production in M. flexuosa, which dictate in part, foraging patterns and movement of frugivores. Land managers can use this information to predict resource availability for frugivores and seed dispersal patterns of M. flexuosa. Further, results from my dissertation can be applied to effective management and sustainable harvesting of M. flexuosa. Not only must managers understand phenology, sex ratios, and pollination, but they may also use vegetative attributes to predict buriti fruit yields. 


\section{LITERATURE CITED}

Bazzaz, F.A., Chiariello, N.R., Coley, P.D., and Pitelka, L.F. 1987. Allocating resources to reproduction and defense. Bioscience 37(1):58-67.

Belcher, B., Ruís-Pérez, M., and Achdiawan, R. 2005. Global patterns and trends in the use and management of commercial NTFPs: implications for livelihoods and conservation. World Development 33:1435-1452.

Brown, B.J., Mitchell, R.J., and Graham, S.A. 2002. Competition for pollination between an invasive species (purple loosestrife) and a native congener. Ecology 83:23282336.

Castro, J., Zamora, R., Hódar, J.A., and Gómez, J.M. 2004. Seedling establishment of a boreal tree species (Pinus sylvestris) at its southernmost distribution limit: consequences of being in a marginal Mediterranean habitat. Journal of Ecology 92(2):266-277.

Colwell, R.K., Brehm, G., Cardelús, G.L., Gilman, A.C., and Longino, J.T. 2008. Global warming, elevational range shifts, and lowland biotic attrition in the wet tropics. Science 322(5899):258-261.

Culley, T. M., Weller, S.G., and Sakai, A.K. 2002. The evolution of wind pollination in angiosperms. Trends in Ecology and Evolution 17:361-369.

Edwards, D.M. 1996. The trade in non-timber forest products from Nepal. Mountain Research and development 16(4):383-394.

Ellison, A.M., Bank, M.S., Clinton, B.D., Colburn, E.A., Elliott, K., Ford, C.R., Foster, D.R., Kloeppel, B.D., Knoepp, J.D., Lovett, G.M., Mohan, J., Orwig, D.A., Rodenhouse, N.L., Sobczak, W.V., Stinson, K.A. et al. 2005. Loss of foundation species: consequences for the structure and dynamics of forested ecosystems. Frontiers in Ecology and the Environment 3:479-486.

Ervik, F. 1993. Notes on the phenology and pollination of the dioecious palm Mauritia flexuosa (Calamoideae) and Aphandra natalia (Phytelephantoideae). In Barthlott, W., Naumann, C.M., Schmidt-Loske, K., and Schuchmann, K.L., eds. Animal plant interactions in tropical environments, pages 7-12. Bonn, Zoologisches Forschunginstitut und Museum Alexander Koenig.

Fagan, W.F., Cantrell, R.S., and Cosner, C. 1999. How habitat edges change species interactions. The American Naturalist 153(2):165-182.

Fuchs, E.J., Lobo, J.A., and Quesada, M. 2003. Effects of forest fragmentation and flowering phenology on the reproductive success and mating patterns of the tropical dry forest tree Pachira quinata. Conservation Biology 17(1):149-157. 
Guisan, A. and Zimmermann, N.E. 2000. Predictive habitat distribution models in ecology. Ecological Modelling 135:147-186.

Hedhly, A., Hormaza, J.I., and Herrero, M. 2009. Global warming and sexual plant reproduction. Trends in Plant Science 14(1):30-36.

Hill, J.K. and Hamer, K.C. 1998. Using species abundance models as indicators of habitat disturbance in tropical forests. Journal of Applied Ecology 35(3):458-460.

Jennersten, O.1988. Pollination in Dianthus deltoides (Caryophyllaceae): effects of habitat fragmentation on visitation and seed set. Conservation Biology 2(4):359366.

Kareiva, P. 1987. Habitat fragmentation and the stability of predator-prey interactions. Nature 326:388-390.

King, J.R., Andersen, A.N., and Cutter, A.D. 1998. Ants as bioindicators of habitat disturbance: validation of the functional group model for Australia's humid tropics. Biodiversity \& Conservation 7(12):1627-1638.

Klein, A.M., Steffan-Dewenter, I., and Tscharntke, T. 2003. Fruit set of highland coffee increases with the diversity of pollinating bees. Proceedings of the Royal Society of London, B, 270(518): 955-961.

Laurance, W.F. and Williamson, G.B. 2001. Positive feedbacks among forest fragmentation, drought, and climate change in the Amazon. Conservation Biology 15(6):1529-1535.

Lovejoy, T.E., Bierregaard Jr., T.O., Rylands, A.B., Malcolm, J.R., Quintela, C.E., Harper, L.H., Brown Jr., K.S., Powell, A.H., Powell, G.V.N., Schubart, H.O.R., and Hays, M.B. 1986. Edge and other effects of isolation on amazon forest fragments. In Soulé, M.E., ed., Conservation biology: the science of scarcityand diversity, pages 257-285. Sunderland, Sinauer.

Malhi, Y., Timmons Roberts, J., Betts, R.A., Killeen, T.J., Li, W., and Nobre, C.A. 2008. Climate change, deforestation, and the fate of the Amazon. Science 319(5860):169-172.

Parminter, J. 1998. Natural disturbance ecology. In Voller, J. and Harrison, S., eds. Conservation biology principles for forested landscapes, pages 3-41. Vancouver, UBC Press.

Parrotta, J.A. and Knowles, O.H. 1999. Restoration of tropical moist forests on bauxitemined lands in the Brazilian Amazon. Restoration Ecology 7(2):103-116.

Penn Jr., J.W. 2006. The cultivation of camu camu (Myrciaria dubia): a tree planting programme in the Peruvian Amazon. Forests, Trees and Livelihoods 16(1):85101. 
Post, E. and Stenseth, N.C. 1999. Climatic variability, plant phenology, and northern ungulates. Ecology 80(1322):1322-1339.

Rathcke, B.J. and Jules, E.S. 1993. Habitat fragmentation and plant-pollinator interactions. Current Science 65(3):273-277.

Smith, M.D. and Knapp, A.L. 2003. Dominant species maintain ecosystem function with non-random species loss. Ecology Letters 6(6):509-517.

Stebbins, G.L. 1970. Adaptive radiation of reproductive characteristics in angiosperms, I: pollination mechanisms. Annual Review of Ecology and Systematics 307-326.

Steffan-Dewenter, I. and Tscharntke, T. 1999. Effects of habitat isolation on pollinator communities and seed set. Oecologia 121(3):432-440.

Stenseth, N.C., Mysterud, A., Ottersen, G., Hurrell, J.W., Chan, K.S., and Lima, M. 2002. Ecological effects of climate fluctuations. Science 297(1292):1292 -1296.

Storti, E.F. 1993. Biologia floral de Mauritia flexuosa Lin. Fil. na região de Manaus, AM, Brasil. Acta Amazônica 23:371-381.

Traveset, A. and Richardson, D.M. 2006. Biological invasions as disruptors of plant reproductive mutualisms. Trends in Ecology and Evolution 21(4):208-216.

Valencia, R., Foster, R.B., Villa, G., Condit, R., Svenning, J.C., Hernández, C., Romoleroux, K., Losos, E., Magård, E., and Balslev, H. 2004. Tree species distributions and local habitat variation in the Amazon: large forest plot in eastern Ecuador. Journal of Ecology 94:214-229.

van Asch, M., van Tienderen, P.H., Holleman, L.J.M., and Visser, M.E. 2007. Predicting in response to climate change, an insect herbivore example. Global Change Biology 13(8):1596-1604.

Walker, M.D., Ingersoll, R.C., and Webber, P.J. 1995. Effects of interannual climate variation on phenology and growth of two alpine forbs. Ecology 76(4):10671083.

Wollenberg, E.K. 2001. Incentives for collecting Gaharu (fungal-infected wood Ofaquilaria spp.; Thymelaeaceae) in east Kalimantan. Economic Botany 55(3):444-456.

Wookey, P.A., Parsons, A.N., Welker, J.M., Potter, J.A., Callaghan, T.V., Lee, J.A, and Press, M.C. 1993. Comparative responses of phenology and reproductive development to simulated environmental change in sub-arctic and high arctic plants. Oikos 67(3):490-502. 
VITA

\section{ROXANEH KHORSAND ROSA}

\section{EDUCATION}

University of Colorado, Boulder, CO.

Bachelors of Arts, Ecology and Evolutionary Biology, 2003.

Bachelor of Arts, Spanish Literature, 2003.

\section{GRANTS AND AWARDS}

Botanical Society of America (BSA) Travel Award, \$500, 2012.

FIU Dissertation Year Fellowship, \$25,000, Summer 2012.

NSF Supplement to Doctoral Dissertation Enhancement Project Award, \$3,000, 2011.

NSF Doctoral Dissertation Enhancement Project Award, \$15,000, 2009 - 2010.

Fulbright Scholar Grant, \$15,000, 2009 - 2010.

Montgomery Botanical Center Research Fellowship, \$1,000, 2009.

Tinker Field Research Grant, \$2,500, 2009.

Montgomery Botanical Center Research Fellowship, \$1,000, 2008.

International Palm Society Fellowship, \$4,500, 2008.

NSF Graduate Research Fellowship, Honorable Mention, 2008.

FIU Agroecology Scholarship, \$2,500, 2008.

FIU Pearce Scholarship, \$2,000, 2008.

NSF Cyber Bridges Award, \$5,000, 2007.

FIU Judith Evans Parker Travel Scholarship, \$1,100, 2007. 


\section{PUBLICATIONS AND PRESENTATIONS}

Khorsand Rosa, R. \& Koptur, S. 2013. New findings on the pollination biology of Mauritia flexuosa (Arecaceae) in Roraima, Brazil: linking dioecy, wind, and habitat. American Journal of Botany 100:613-621.

Khorsand Rosa, R. 2011. Bees collect resin from Mauritia flexuosa in Roraima, Brazil. PALMS 55(4): 200-203.

Khorsand Rosa, R. and S. Koptur. 2009. Preliminary observations and analyses of pollination in Coccothrinax argentata: Do insects play a role? PALMS 53(2): 75-83.

Khorsand Rosa, R. and Koptur, S. Reconsidering wind-pollination in the tropics: a case study of Mauritia flexuosa (Arecaceae). FIU Biology Symposium, Miami, FL; 02/2013; Honorable Mention.

Khorsand Rosa, R., S. Koptur, and R.I. Barbosa. Floral biology and pollination of the agroforestry palm, Mauritia flexuosa: Why field observations are not enough. Botanical Society of America Conference, Columbus, OH; 07/2012; $1^{\text {st }}$ Place, Best Graduate Student Talk.

Khorsand Rosa, R. Phenology and population dynamics of Mauritia flexuosa (Buriti) in Roraima, Brazil. Plant Biologists of South Florida Annual Meeting, Miami, FL., $04 / 2012$.

Khorsand Rosa, R. Phenology and population dynamics of Mauritia flexuosa (Buriti) in Roraima, Brazil. FIU Biology Symposium, Miami, FL., 01/2012. ${ }^{\text {st }}$ place, Best Graduate Student Talk.

Khorsand Rosa, R. The reproductive ecology of Buriti in Roraima. Federal University of Roraima (UFRR), Boa Vista, Roraima, Brazil; 03/2010.

Khorsand Rosa, R. and S. Koptur. Poster presentation: The pollination biology of three sympatric palms of southern Florida pine rocklands. Ecological Society of America's Plant-Pollinator Interactions Conference, Milwaukee, WI.; 08/2008.

Khorsand Rosa, R. The ecological basis for fruit productivity in Mauritia flexuosa L.f.: Does habitat matter? South Florida Palm, Miami, FL.; 07/2008.

\section{OUTREACH}

Educational presentations at Henry E.S. Reeves Elementary, Miami. FL., Career Day; 09/2012, 02/2013.

Environmental outreach presentations with school children and community members in Roraima, Brazil; 12/2010-05/2011.

Earth Week presentation: The pollination system of angiosperms. Integrated Museum of Roraima (MIRR), Boa Vista, Roraima, Brazil; 06/2011. 